\title{
37. CENOZOIC COCCOLITH, SILICOFLAGELLATE, AND DIATOM STRATIGRAPHY, DEEP SEA DRILLING PROJECT LEG 44
}

\author{
David Bukry, United States Geological Survey, La Jolla, California
}

\section{INTRODUCTION}

Leg 44 of the Deep Sea Drilling Project, which began at Norfolk, USA, August 1975, and ended at Norfolk, USA, September 1975, recovered 149 cores at five sites, 388-392 (Figure 1). Light-microscope techniques were used to study the Cenozoic coccoliths and silicoflagellates of 116 samples from these cores. Nine samples from Site 394 drilled during Leg 44A (November 1975), an engineering trial of equipment for IPOD, were also studied. Coccolith zonation of the samples, summarized in Figure 2, follows Bukry (1973a; 1975a). Silicoflagellate zonation is explained in text. Siliceous sponge spicules, which are abundant in some Eocene and Miocene samples at Sites 390 and 391, are illustrated (Plates 10-14).

A new silicoflagellate biostratigraphic unit, the lower Eocene Naviculopsis robusta Subzone, and nine new taxa of silicoflagellates are described: Corbisema toxeuma n. sp., C. triacantha convexa n. subsp., $C$. ? xenica n. sp., Distephanus? acanthicus n. sp., D. crux loeblichii $\mathrm{n}$. subsp., D. trioctus n. sp., Mesocena diodon nodosa n. subsp., Naviculopsis foliacea tumida n. subsp., and $N$. obtusarca $\mathrm{n}$. sp. One recombination is proposed: Distephanus speculum polyommata (Schulz) n. comb.

\section{SITE SUMMARIES}

Site 388

(lat $35^{\circ} 31.33^{\prime} \mathrm{N}$, long $69^{\circ} 23.76^{\prime} \mathrm{W}$, depth $4919 \mathrm{~m}$ )

Site 388 , located at the base of the continental rise east of Cape Hatteras, was cored to determine the origin of the lower continental rise hills and the nature and age of sediments associated with prominent acoustic reflectors. There was no recovery in Hole 388; all cores were taken from Hole 388A. Coccolith assemblages in Cores 2 to 11 ( 37 to $341 \mathrm{~m}$ ) range from lower Quaternary to upper Miocene. The assemblages are, generally, sparse and strongly etched. The Quaternary Gephyrocapsa caribbeanica Subzone of Sample 388A-2-3, 75-77 cm (40m), contains reworked Cretaceous and Eocene coccoliths. Samples examined from Cores 6 to 11 (284 to $341 \mathrm{~m}$ ) all contain a sparse Miocene assemblage which probably belongs to the upper Miocene Discoaster neohamatus Zone. This correlation is based on the presence of Discoaster bellus, $D$. brouweri s. ampl., $D$. pentaradiatus, $D$. prepentaradiatus, and Minylitha convallis, which are typically associated in the zone. The presence of Discoaster bollii and the absence of Catinaster calyculus or Discoaster hamatus in Core 11 suggests that the deepest sediment sampled $(341 \mathrm{~m})$ belongs to the lower part of the Miocene Discoaster neohamatus Zone.

\section{Site 389}

\author{
(lat $30^{\circ} 08.54^{\prime} \mathrm{N}$, long $76^{\circ} 05.57^{\prime} \mathrm{W}$, depth $2724 \mathrm{~m}$ )
}

Site 389 , located on the Blake Nose east of Jacksonville, was an abortive attempt to recover a sediment section to identify regional seismic reflectors and to determine the geologic history of a supposed Cretaceous reef complex and overlying pelagic sediments. Only a single core from the surface was recovered when the drill string was deflected by a gravel veneer of manganese nodules and shells. Quaternary coccoliths, such as Gephyrocapsa oceanica, are mixed with Pliocene (Discoaster tamalis) and Cretaceous (Cretarhabdus crenulatus) coccoliths in Sample 389-1-2, $75-77 \mathrm{~cm}$.

\section{(lat $30^{\circ} 08.54^{\prime} \mathrm{N}$, long $76^{\circ} 06.74^{\prime} \mathrm{W}$, depth $2670 \mathrm{~m}$ )}

Site 390 , located on the Blake Nose, was a second attempt (following an unsuccessful attempt at Site 389) to identify regional seismic reflectors and determine the geologic history of a Cretaceous reef complex and overlying sediments on the Blake Plateau. Cenozoic coccolith assemblages range in age from early Paleocene Cruciplacolithus tenuis Zone to middle Eocene Reticulofenestra umbilica Zone. Middle Eocene assemblages are exceptionally diverse as nearshore and oceanic species occur together. The pentaliths Braarudosphaera and Micrantholithus which are most common in shallow marine deposits are common in Hole 390 middle Eocene Cores 1 and Hole 390A Cores 1 to 4 ( 0 to $48 \mathrm{~m})$. The same interval contains common to abundant siliceous sponge spicules produced by desmosponges and hexactinellids which presently live most commonly at 0 to 50 meters and 500 to 1000 meters of water, respectively (Hyman, 1940). Silicoflagellates are rare.

The lower Eocene, in constrast, has common to few silicoflagellates, few pentaliths, and common sponge spicules. A reduction in the abundance of diatoms and silicoflagellates and the increase in pentaliths suggests some shoaling of the plateau from early to middle Eocene or a change in the character of upwelling in the area.

The middle Eocene Chiasmolithus gigas Subzone of Hole 390A, Core 4, is characterized by an abundance of Braarudosphaera discula comparable to coeval deposits from the nearby Gulf of Mexico (DSDP Site 94) and Bahama Banks (DSDP Site 98) (Bukry, 1972; 1973b). Other species in the assemblages include: Braarudosphaera bigelowii, B. rosa, Campylosphaera dela, Chiasmolithus expansus, C. gigas, C. grandis, Coccolithus formosus, Cyclicargolithus pseudogammation, Cyclolithella? bramlettei, Discoaster 


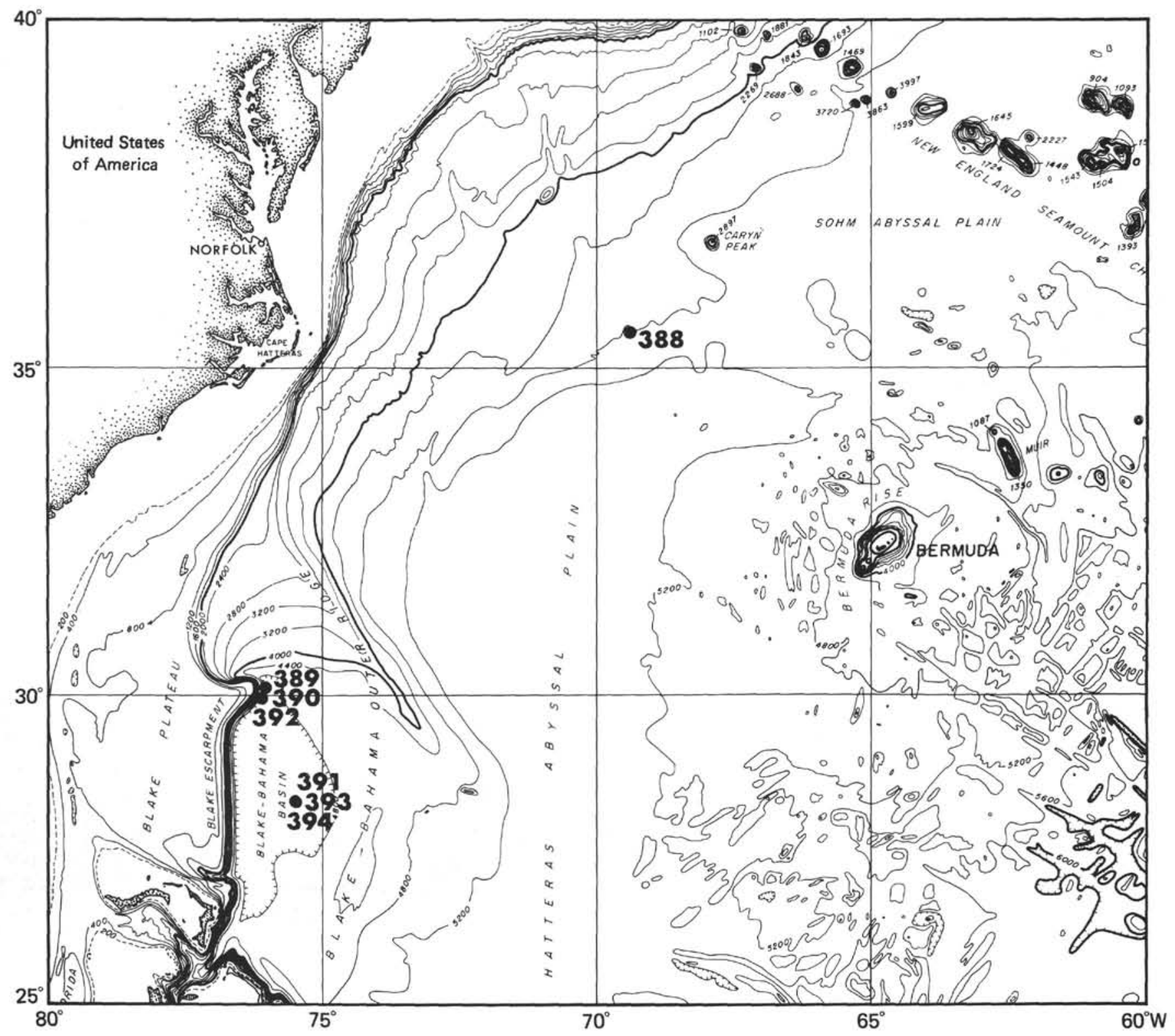

Figure 1. Sketch map of sites drilled on Deep Sea Drilling Project Leg 44.

barbadiensis, D. distinctus, D. nodifer, Micrantholithus inaequalis, $M$. procerus, Nannotetrina sp., Sphenolithus spiniger, Triquetrorhabdulus inversus.

Pentaliths and Zygrhablithus sp. cf. Z. bijugatus also occur commonly in lower Eocene assemblages, indicating cool or marginal marine conditions. Zygrhablithus are most prominent in the Discoaster lodoensis Zone of Hole 390, Core 6, pentaliths in the Tribrachiatus orthostylus Zone of Hole 390A, Core 7. Species in Sample 390A-6-6, 118-120 $\mathrm{cm}(66 \mathrm{~m})$, include: Campylosphaera dela, Chiasmolithus grandis, Coccolithus crassus, C. cribellum, C. formosus, C. magnicrassus, Cyclicargolithus sp. cf. C. pseudogammation, Discoaster barbadiensis, D. lodoensis, and Zygrhablithus bijugatus. Assemblages from the $T$. orthostylus Zone of Hole 390, Core 7 differ in the absence of Coccolithus crassus, the presence of Tribrachiatus orthostylus, and the more common occurrences of
Braarudosphaera bigelowii, Campylosphaera dela, Lophodolithus nascens, Micrantholithus flos, and Sphenolithus radians $\mathrm{s}$. ampl.

The lower Paleocene Cruciplacolithus tenuis Zone in Hole 390A, Cores 9 to 11 (86 to $114 \mathrm{~m}$ ) contains reworked Cretaceous Arkhangelskiella throughout. The lower part of the zone contains abundant Biscutum dimorphosus, a typical Danian coccolith (PerchNielsen, 1969). Heliorthus chiastus first occurs in the upper part of the interval, suggesting a rather complete representation of the Danian at this site.

\section{Site 391}

(lat $28^{\circ} 13.67^{\prime} \mathrm{N}$, long $75^{\circ} 36.88^{\prime} \mathrm{W}$, depth $4963 \mathrm{~m}$ )

Site 391 , located in the abyssal Blake-Bahama Basin, was cored to date regional seismic reflector horizons 


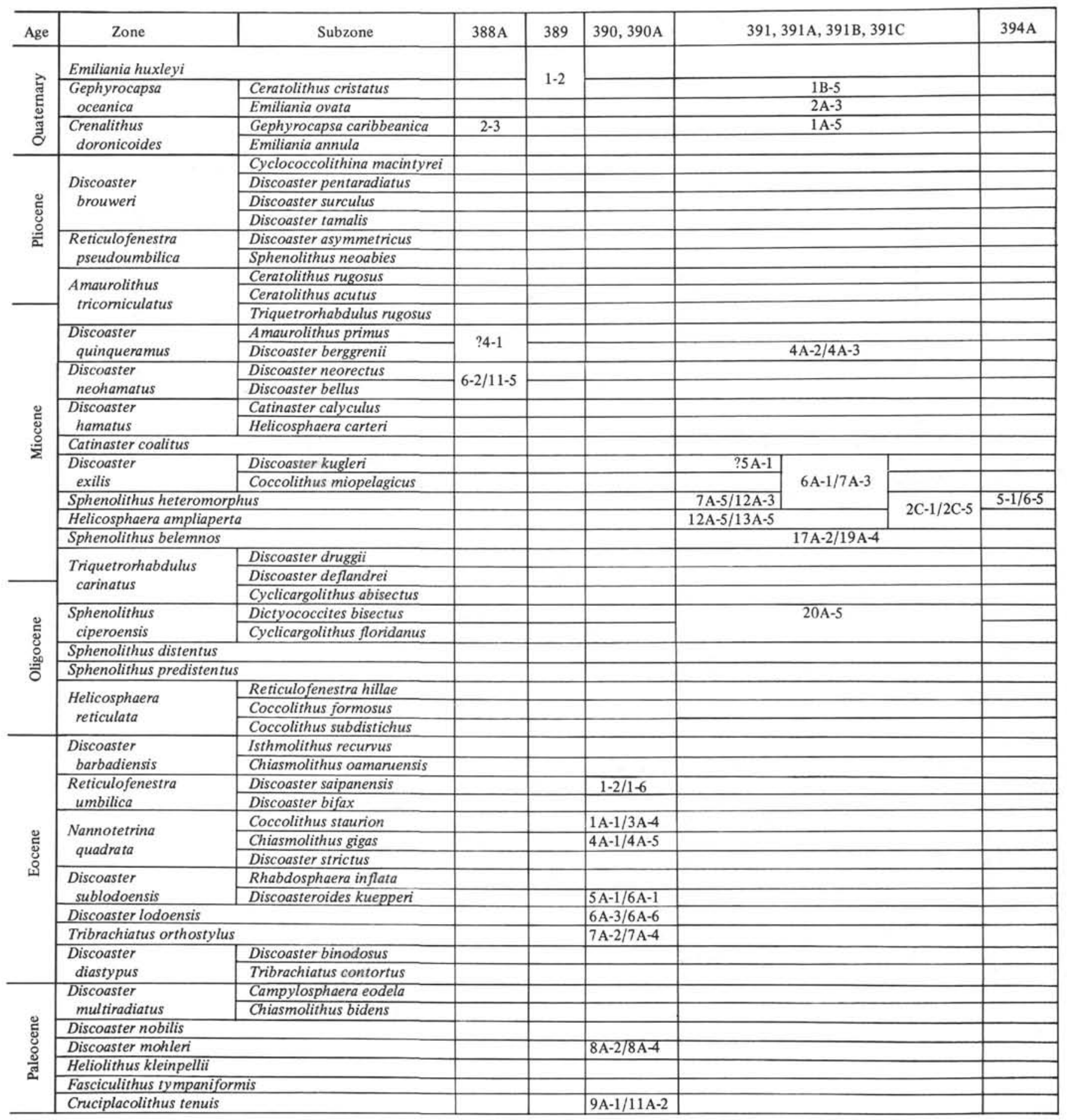

Figure 2. Cenozoic coccolith zonation (Bukry, 1975) for Leg 44 and Leg 44 A.

and old Mesozoic sediment. The Cenozoic section from 0 to 621 meters was discontinuously cored and is mainly a lower middle Miocene turbidite of muddy siliceous ooze clasts in a marly coccolith chalk matrix. Diatoms, silicoflagellates, and siliceous sponge spicules are common in dark green claystones and sparse in the coccolith chalk lithology. The ages of the siliceous and calcareous microfossil assemblages are very similar. Cores 7 to 13 from Hole $391 \mathrm{~A}$ (326 to $535 \mathrm{~m}$ ) are correlative to the diatom Craspedodiscus coscinodiscus Zone containing Coscinodiscus lewisianus (Bukry and
Foster, 1973); silicoflagellate Corbisema triacantha Zone (Martini, 1971); and coccolith Helicosphaera ampliaperta Zone and Sphenolithus heteromorphus Zone (Bukry, 1973a). Sparse late Oligocene or early Miocene siliceous taxa are reworked in Hole 391A, Core 10. An abundance of siliceous sponge spicules in Cores 10, 12, and 13 suggests that much of the sediment was redeposited from shallower environments.

Quaternary coccolith assemblages containing reworked specimens of Cretaceous, Eocene, and Pliocene age were recovered between 0 and 96 meters in 
Hole 391B. Sample 391B-1-5, $97-99 \mathrm{~cm}$ (7 m), from the shallowest core contains an exceptional population of large Coccolithus pelagicus having a wide central opening and crossbar. Other taxa present include: Ceratolithus cristatus, Cyclococcolithina leptopora, Gephyrocapsa caribbeanica, G. oceanica, Helicosphaera carteri, $H$. sellii, and reworked taxa, Discoaster variabilis and Prediscosphaera cretacea. A technical problem resulted in Core 1, Hole 391A ( 86 to $96 \mathrm{~m}$ ) being cut below Core 2 (32 to $41 \mathrm{~m})$. The assemblage of Core 2 is younger, as indicated by the presence of Gephyrocapsa oceanica and G. omega.

Samples from Hole 391A, Core 3 (146 to $155 \mathrm{~m}$ ) are mainly calcareous debris containing few coccoliths that are of mixed ages and are poorly preserved. Ascidian spicules and the diatom genus Melosira further suggest a shallower source for the redeposited sediment. The assemblages are middle Miocene or younger on the basis of the presence of Cyclococcolithina macintyrei.

Hole $391 \mathrm{~A}$, Core 4 (203 to $212 \mathrm{~m}$ ) also contains shallow-water ascidian spicules, but coccoliths are abundant and include the upper Miocene guide species Discoaster quinquieramus. The samples are assigned to the Discoaster berggrenii Subzone because Amaurolithus is not present.

Middle Miocene samples from Hole 391A, Cores 5 to $12(260$ to $478 \mathrm{~m})$ contain poorly preserved coccolith assemblages with reworked forms sparse to common. Discoasters have heavy irregular overgrowths in Cores 5 and 6 that make species identifications questionable. Two questionable specimens of Discoaster kugleri and the sparse occurrence of Sphenolithus heteromorphus (probably reworked) suggest the provisional Discoaster kugleri Subzone assignment of Sample 391A-5-1, 86-88 $\mathrm{cm}(260 \mathrm{~m})$. The increased percentages of Distephanus longispinus and Mesocena diodon (some noded) among the silicoflagellates in Core 7 also support a middle middle Miocene position for Core 5 .

Most discoasters from Hole 391A, Cores 7 and 8 (326 to $345 \mathrm{~m}$ ) are etched. The specimens from Samples $391 \mathrm{~A}-7-3,86-88 \mathrm{~cm}(329 \mathrm{~m})$ and $391 \mathrm{~A}-8-1,130-132 \mathrm{~cm}$ $(337 \mathrm{~m})$ are almost all thin, ghost-like, dissolution remnants. Owing to the poor preservation and mixing of assemblages, zonal boundaries are provisional. For example, in Sample 391A-11-3, 56-58 cm (415 m), reworked Oligocene and Eocene taxa are common-Braarudosphaera bigelowii, B. discula, Chiasmolithus grandis, Dictyococcites bisectus, Discoaster barbadiensis, D. deflandrei, D. saipanensis, Micrantholithus procerus, Quinquerhabdus colossicus, Reticuloferiestra reticulata, $R$. umbilica, and Sphenolithus distentus. Some of the $D$. deflandrei, $D . \mathrm{sp}$. cf. D. exilis, and Sphenolithus heteromorphus in the sample are presumed to be in place and indicate the Sphenolithus heteromorphus Zone, because Helicosphaera ampliaperta present below in basal Cores 12 and 13 is missing at higher levels.

The presence of Helicosphaera ampliaperta in Sample $391 \mathrm{~A}-13-5,29-31 \mathrm{~cm}(532 \mathrm{~m})$, places a maximum age limit of approximately 17 m.y. (Bukry, 1975a) on the 535-meter level. Coccolith assemblages available from Hole 391A, Core 17 (564 to $573 \mathrm{~m}$ ) lack Sphenolithus heteromorphus and $H$. amplaperta. These assemblages which contain a late variety of Sphenolithus dissimilis and that of Sample 391A-19-4, 137-139 cm (587 m), which contains $S$. sp. cf. $S$. belemnos and $S$. dissimilis, are assigned to the Sphenolithus belemnos Zone. The next older guide fossil Discoaster druggii is missing.

The oldest Cenozoic coccolith assemblage from Sample 391A-20-5, $85-87 \mathrm{~cm}(646 \mathrm{~m})$, belongs to the late Oligocene Sphenolithus ciperoensis Zone based on the common occurrence of Cyclicargolithus abisectus, Dictyococcites bisectus, and Sphenolithus ciperoensis. Triquetrorhabdulus carinatus and Zygrhablithus bijugatus are also present. Reworking of older, Eocene or Oligocene, specimens is shown by the presence of Discoaster barbadiensis, D. nodifer, and Reticulofenestra umbilica. Younger guide fossils Discoaster druggii and Sphenolithus belemnos are missing.

Reworking is especially abundant in Hole 391C, Core $2(611$ to $621 \mathrm{~m})$. Whereas the presence of Sphenolithus heteromorphus indicates a maximum age of approximately $17 \mathrm{~m} . y$. for the assemblage, older reworked Eocene, Oligocene, and Cretaceous coccoliths have greater diversity than the indigenous Miocene assemblage. Reworked taxa include: Braarudosphaera bigelowii, Bramletteius serraculoides, Cretarhabdus crenulatus, Cribrosphaera ehrenbergii, Coccolithus formosus, Cyclococcolithina? kingii, Discoaster barbadiensis, D. saipanensis, D. tanii, Eiffellithus eximius, Helicosphaera compacta, $H$. heezenii, Micrantholithus procerus, Peritrachelina joidesa, Prediscosphaera cretacea, Quinquerhabdus colossicus, Reticulofenestra umbilica, Sphenolithus ciperoensis, $S$. distentus, $S$. predistentus, $S$. pseudoradians, Thoracosphaera prolata, and Triquetrorhabdulus inversus.

\section{Site 392 \\ (lat $29^{\circ} 54.63^{\prime} \mathrm{N}$, long $76^{\circ} 10.68^{\prime} \mathrm{W}$, depth $2607 \mathrm{~m}$ )}

Site 392 is located on the Blake Nose reef structure. The shallowest sample available, 392A-1-2, 61-62 cm (52 m), contains Broinsonia parca and Tetralithus trifidus, indicating the late Campanian or early Maestrichtian Tetralithus trifidus Zone. See reports of shipboard scientists for detailed biostratigraphy.

Site 393 (Engineering Leg 44A)

(lat $28^{\circ} 11.80^{\prime} \mathrm{N}$, long $75^{\circ} 35.94^{\prime} \mathrm{W}$, depth $4962 \mathrm{~m}$ )

No samples available; shipboard scientists report recovery of two cores of nannofossiliferous Quaternary silty clay in which reworking from older deposits is evident.

\section{Site 394 (Engineering Leg 44A) \\ (lat $28^{\circ} 11.70^{\prime} \mathrm{N}$, long $75^{\circ} 35.76^{\prime} \mathrm{W}$. depth $4962 \mathrm{~m}$ )}

Site 394, located about 300 meters south of Site 393 in the Blake-Bahama Basin, was drilled to fill in some uncored gaps in the stratigraphic section of nearby Site 391. Samples available from Cores 5 ( 279 to $289 \mathrm{~m}$ ) and 6 (355 to $365 \mathrm{~m}$ ) contain the same Sphenolithus heteromorphus Zone chalk breccia that was recovered at Site 391 between 326 and 478 meters. Diatoms, radiolarians, silicoflagellates, and siliceous sponge spicules are common in dark green claystone 
clasts; coccoliths predominate in the chalk matrix. Separate smear slides of a green clast and the chalk matrix from Sample 394A-5-3, 73-76 cm (283 m), show that both contain $S$. heteromorphus Zone coccoliths, but the clast assemblage lacks reworked coccoliths. The clast is distinguished by correlative diatoms and silicoflagellates: Craspedodiscus coscinodiscus Zone and Corbisema triacantha Zone. Furthermore, the clast contains common and diverse siliceous sponge spicules suggesting a less than abyssal accumulation site for the claystone. The chalk matrix is distinguished by the common occurrence of reworked coccoliths of Cretaceous, Eocene, and Oligocene age. Lower Miocene silicoflagellates of genus Naviculopsis are absent in clast samples from Hole 394A, and are rare or absent in acidized bulk samples from Site 391, which suggests the clasts and matrix are of similar age. Apparently both the clasts and matrix have been redeposited from the Blake Plateau and Blake Escarpment into the Blake-Bahama Basin.

\section{MIOCENE AND EOCENE SPONGE SPICULES}

Siliceous sponge spicules are common in Miocene samples from Site 391 and in Eocene samples from Site 390 which were acidized for silicoflagellate studies. The forms of the spicules are diverse and there are many shapes in common even though a $30 \mathrm{~m}$.y. difference in age exists between the two assemblages.

Sponges (Porifera) are benthic organless metazoans with a geologic record extending from the Cambrian to the present. The sponge skeleton consists of calcareous or siliceous spicules or spongin fibers (Hyman, 1940). There is a great variety of spicule shapes, and these are used for description and identification of modern sponges. The complex terminology used to identify spicules from modern sponges can be applied to Miocene and Eocene fossil spicules because of a general similarity in the most common forms.

A single living sponge contains several different forms of spicules and the same type of spicule can be produced by different species (Hyman, 1940). As a result, fossil spicule assemblages from deep-sea sediments that are a mixture of isolated spicules cannot be identified using a natural linnean taxonomy. Ehrenberg's (1854) artificial linnean taxonomy for fossil sponges or the modern descriptive terminology for isolated spicules could be used (for example, Hyman, 1940). Additional descriptive terms or taxa may be needed for unusual fossil forms.

For this preliminary report the descriptive terms are used. References showing the application of descriptive terms for sponge spicules include Dumitrica (1973a), Minchin et al. (1900), Hyman (1940), Ridley (1887), Schulze (1887), I.B.J.Sollas (1906), and W.J.Sollas (1888). Although Ehrenberg (1854) did not use descriptive terms for isolated fossil sponge spicules, he provided excellent illustrations, particularly of Miocene forms.

Acanthostyle: Spiny style.

Anatriaene: Style having a three-rayed crown.

Anisochela: Chela having inequant ends.
Calthrop: Tetraxon having four rays approximately equal.

Centrotriaene: Elaborately branched triaene, smooth or tufted (see Sollas, 1888, pl. 35).

Chela: C-shaped spicules having plates at the ends.

Dichotriaene: Triaene having bifid rays making up the crown.

Discaster: Monaxon having two discoidal enlargements near the center.

Isochela: Chela having equant ends.

Oxea: Monaxon having two equally pointed ends. May be curved or straight, with smooth, spined or mammillary surfaces.

Plesioaster: Monaxon having a few spines from a short axis.

Spheraster: Polyaxon having distinct rays about a large center.

Spiraster: Short spiny monaxon that is spirally twisted.

Sterraster: Polyaxon having a spherical surface with short ray projections.

Strongyle: Monaxon having two simple, equant, rounded ends. May be smooth or noded, curved or straight.

Style: Monaxon having one end rounded and tapering to a point at the other end.

Triaene: Style having a simple pointed end and larger trifid end or crown.

Trichotriaene: Triaene having trifid rays making up the crown.

Triod: Simple triaxial spicule having pointed ends.

Tylostyle: Style having a bulbous end.

Tylote: Strongyle having two equant bulbous ends. May be smooth or spined.

\section{MIOCENE AND EOCENE DIATOMS}

Some notes which were made incidental to silicoflagellate studies on the occurrence of Miocene and Eocene diatoms from cores of Legs 44 and 44A are presented to aid future study of the core samples. Detailed diatom study still needs to be done.

Miocene diatoms from the Blake-Bahama Basin are most abundant and diverse in Cores 7 to 13 from Hole 391A and Cores 5 and 6 from Hole 394A. These diatom assemblages are assigned to the early and middle Miocene Craspedodiscus coscinodiscus Zone (see Burckle, 1972, Nova Hedwigia, v. 39, p. 217-246 and Bukry and Foster, 1973) or NPD Zones 23 to 25 and below (Schrader, 1973, DSDP, v. 18, p. 673-797).

The stratigraphic guide species Craspedodiscus coscinodiscus occurs through Cores 7 to 13 and 5 to 6 at both holes, whereas, the guide species Annellus californicus and Coscinodiscus lewisianus are basically restricted to Cores 10 to 13 at Hole $391 \mathrm{~A}$ (Figure 3). The distinctive cylindershaped $A$. californicus has a short range across the lower to middle Miocene boundary and occurs here with coccoliths of the Helicosphaera ampliaperta Zone and Sphenolithus heteromorphus Zone. Actinocyclus ingens occurs only in the upper $C$. coscinodiscus Zone (Cores 7 to 9) with $S$. heteromorphus Zone coccoliths (see Barron, 1976, Marine Micropaleontology, v. 1, p. 27-63). 


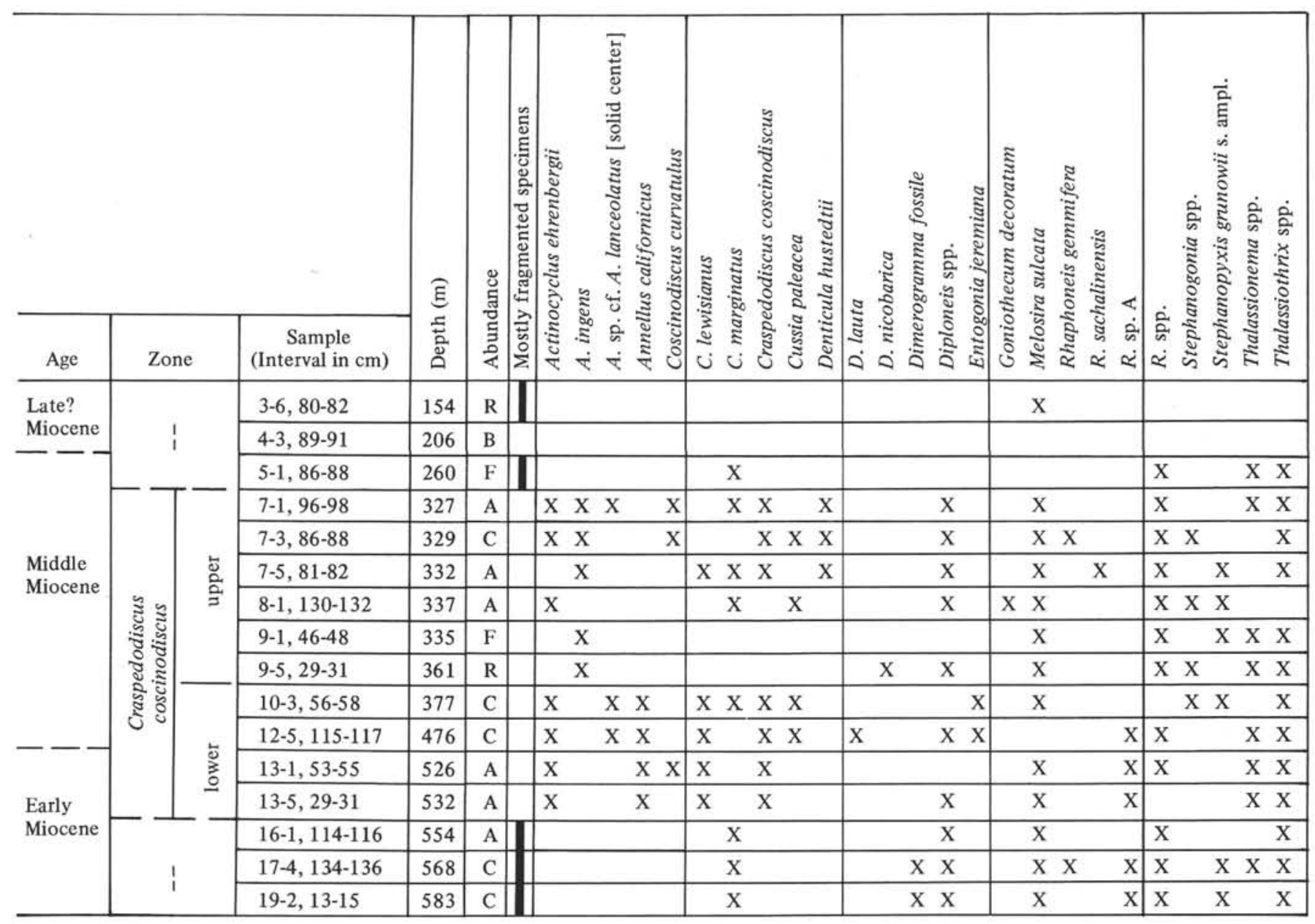

Figure 3. Occurrence of diatoms in Miocene sediment from Site 391, as noted during silicoflagellate studies. The distribution of Annellus californicus and Actinocyclus ingens at Site 391 suggests a local division of the Craspedodiscus coscinodiscus Zone into lower and upper subunits.

A potential intergradational relation between Rhaphoneis and Sceptroneis can probably be studied in Cores 7 to 13 because numerous morphotypes of Rhaphoneis occur.

Diatoms are common to abundant in the lower Miocene in Cores 16 to 19 of Hole $391 \mathrm{~A}$, but are highly fragmented and only moderately diverse. The Core 17 sample contains the silicoflagellate Naviculopsis lata and the incertae sedis Macrora stella which together support an early Miocene age for the diatom assemblage.

Some representative Miocene diatom specimens from Hole 391A are illustrated (Plates 9, 18, and 19).

Diatoms are diverse and common to abundant in the middle and lower Eocene in Cores 2 to 7 from Hole 390A on the Blake Nose. Typical assemblages include species of Actinoptychus, Arachnoidiscus, Brightwellia, Coscinodiscus s. ampl., Hemiaulus, Melosira, Triceratium, and Stephanopyxis. Other genera such as Auliscus, Pyxilla, Rhaphoneis, and Trinacria occur in only a few of the samples studied. Melosira and Triceratium are predominant. Specimens of Asterolampra and Asteromphalus were searched for but not found.

The Eocene guide species Coscinodiscus oblongus which occurs in the middle Eocene of the South Atlantic (see Craspedodiscus oblongus from 356-6-6, 130-131 cm, in Bukry, 1977a) occurs in the lower Eocene of the Blake Nose in Sample 390A-6-3, 75-77 cm and 390A-6-4, 75-77 cm. A distinctive Coscinodiscus? sp. that possesses a large central areola (Plate 9, figures 4, 5) also occurs in the same samples from Core 6 , extending its previously known range from middle to early Eocene (Bukry, in press). Some representative Eocene diatom specimens from Hole 390A are illustrated (Plates 9, 15-17).

\section{SILICOFLAGELLATE ZONATION}

Silicoflagellates from Leg 44 and Leg 44A belong to the Miocene Corbisema triacantha Zone and the Eocene Naviculopsis foliacea Zone. The Eocene assemblages are sparse but significant because they are among the first early Eocene sequences from deep-sea cores. They help to refine the ranges of several potential stratigraphic guide species (Dictyocha spinosa, Naviculopsis foliacea foliacea, and $N$. robusta). Zones are discussed from youngest to oldest.

\section{Corbisema triacantha Zone (Martini, 1971, 1972)}

Silicoflagellate assemblages from nearby Sites 391 and 394 in the Blake-Bahama Basin, recovered between 283 and 
532 meters, contain $2 \%$ to $8 \%$ Corbisema triacantha (Figure 4). Naviculopsis lata and $N$. quadrata are rare in only a few samples and are considered to be reworked because they are associated with older Distephanus crux darwinii, Rocella gelida, and $R$. schraderi. The reworked specimens are concentrated in
Core 10 of Hole 391A. The occurrence pattern of Corbisema and Naviculopsis are in agreement with the zone definition-the interval between the extinctions of $N$. quadrata ( $N$. lata, alternate) and $C$. triacantha.

Coccolith zones identified in the same interval are the Miocene Helicosphaera ampliaperta Zone and

\begin{tabular}{|c|c|c|c|c|c|c|c|c|c|c|c|}
\hline \multirow{4}{*}{$\begin{array}{r}\text { Age } \\
\text { Zone } \\
\text { Depth }(\mathrm{m})\end{array}$} & & & & & & & & & \multirow{2}{*}{\multicolumn{3}{|c|}{ Early Miocene }} \\
\hline & & & & Idle $\mathrm{Mi}$ & ocene & & & & & & \\
\hline & \multirow[b]{2}{*}{283} & \multirow[b]{2}{*}{327} & \multicolumn{6}{|c|}{ Corbisema triacantha } & \multirow[b]{2}{*}{476} & \multirow[b]{2}{*}{526} & \multirow[b]{2}{*}{532} \\
\hline & & & 329 & 332 & 337 & 363 & 377 & 381 & & & \\
\hline $\begin{array}{l}\text { Sample } \\
\text { (Interval in } \mathrm{cm})\end{array}$ & 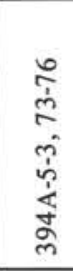 & 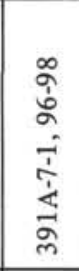 & 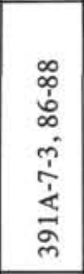 & 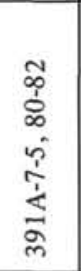 & 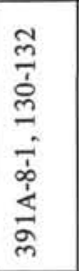 & 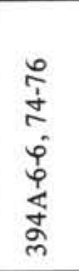 & 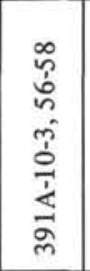 & 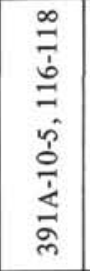 & 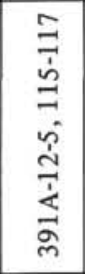 & 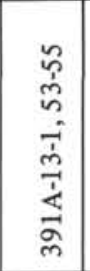 & 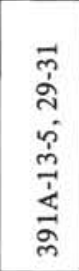 \\
\hline $\begin{array}{l}\text { Cannopilus depressus } \\
\text { C. cf. schulzii } \\
\text { Corbisema triacantha s. ampl. } \\
\text { Dictyocha aff. aspera } \\
\text { D. brevispina ausonia }\end{array}$ & $\begin{array}{l}4 \\
1 \\
1\end{array}$ & $\begin{array}{r}1 \\
3 \\
<1\end{array}$ & $\begin{array}{l}2 \\
1 \\
1\end{array}$ & $\begin{array}{l}3 \\
2\end{array}$ & & $\begin{array}{r}<1 \\
<1 \\
3 \\
1\end{array}$ & $\begin{array}{l}4 \\
5\end{array}$ & 5 & $\begin{array}{l}1 \\
6 \\
1 \\
2\end{array}$ & $\begin{array}{l}6 \\
6\end{array}$ & 8 \\
\hline $\begin{array}{l}\text { D. brevispina brevispina } \\
\text { D. brevispina [variants] } \\
\text { D. fibula fibula } \\
\text { D. fibula [deflandroid or medusoid] } \\
\text { D. pulchella }\end{array}$ & $\begin{array}{l}4 \\
2 \\
3\end{array}$ & $\begin{array}{r}13 \\
1 \\
9\end{array}$ & $\begin{array}{r}12 \\
20 \\
<1 \\
2\end{array}$ & $\begin{array}{r}10 \\
9 \\
6\end{array}$ & & $\begin{array}{r}7 \\
13 \\
3\end{array}$ & $\begin{array}{l}8 \\
1 \\
5 \\
3\end{array}$ & 13 & 20 & $\begin{array}{r}12 \\
1 \\
1 \\
1 \\
\end{array}$ & $\begin{array}{r}9 \\
<1 \\
4\end{array}$ \\
\hline $\begin{array}{l}\text { D. pulchella } \text { [deflandroid] } \\
\text { Distephanus boliviensis major } \\
\text { D. crux crux s. ampl. } \\
\text { D. crux crux? [elliptica-like] } \\
\text { D. crux darwinii [*] }\end{array}$ & 68 & 60 & 52 & 64 & & 65 & $\begin{array}{r}1 \\
59\end{array}$ & $\begin{array}{r}5 \\
57 \\
1\end{array}$ & $\begin{array}{r}2 \\
2 \\
45\end{array}$ & $\begin{array}{r}3 \\
31 \\
<1\end{array}$ & $\begin{array}{r}1 \\
33 \\
2\end{array}$ \\
\hline $\begin{array}{l}\text { D. longispinus } \\
\text { D. cf. longispinus } \\
\text { D. cf. polyactis } \\
\text { D. schauinslandii } \\
\text { D. speculum haliomma } \\
\end{array}$ & 5 & $\begin{array}{l}2 \\
8\end{array}$ & $\begin{array}{r}1 \\
<1\end{array}$ & 3 & & 1 & 2 & & 4 & $\begin{array}{l}2 \\
2 \\
\end{array}$ & 2 \\
\hline $\begin{array}{l}\text { D. speculum hemisphaericus } \\
\text { D. speculum pentagonus } \\
\text { D. speculum polyommata } \\
\text { D. speculum quintus } \\
\text { D. speculum speculum }\end{array}$ & 2 & $<1$ & 1 & 1 & & $<1$ & $\begin{array}{r}<1 \\
1\end{array}$ & 6 & $\begin{array}{r}1 \\
<1 \\
3 \\
\end{array}$ & 1 & 1 \\
\hline $\begin{array}{l}\text { D. speculum triommata } \\
\text { D. cf. staurodon } \\
\text { D. cf. stradneri } \\
\text { Mesocena apiculata apiculata } \\
\text { M. apiculata curvata } \\
\end{array}$ & 1 & $\begin{array}{r}2 \\
<1\end{array}$ & 1 & & & 2 & $\begin{array}{r}2 \\
<1 \\
1 \\
2\end{array}$ & 2 & $\begin{array}{r}1 \\
1 \\
1 \\
<1 \\
2\end{array}$ & $\begin{array}{r}<1 \\
2 \\
2 \\
<1 \\
<1\end{array}$ & $\begin{array}{l}3 \\
1\end{array}$ \\
\hline $\begin{array}{l}\text { M. apiculata glabra } \\
\text { M. diodon s. ampl. } \\
\text { M. elliptica } \\
\text { M. quadrangula s. ampl. } \\
\text { M. triodon } \\
\end{array}$ & $\begin{array}{l}1 \\
1\end{array}$ & $\begin{array}{r}3 \\
<1 \\
1\end{array}$ & $\begin{array}{r}2 \\
2 \\
<1 \\
\end{array}$ & 1 & & $\begin{array}{r}<1 \\
4\end{array}$ & $\begin{array}{l}1 \\
1 \\
4\end{array}$ & & $\begin{array}{r}1 \\
<1\end{array}$ & $\begin{array}{r}29 \\
1\end{array}$ & $\begin{array}{r}<1 \\
31 \\
3\end{array}$ \\
\hline $\begin{array}{l}\text { Naviculopsis biapiculata }\left[{ }^{*}\right] \\
\text { N. lata }\left[{ }^{*}\right] \\
\text { N. ponticula }\left[{ }^{*}\right] \\
\text { N. quadrata }\left[{ }^{*}\right]\end{array}$ & & $<1$ & & & & & $\begin{array}{l}1 \\
1\end{array}$ & $\begin{array}{l}1 \\
1 \\
1\end{array}$ & 1 & & \\
\hline $\begin{array}{l}\text { Rocella gelida }\left[{ }^{*}\right] \\
R . \text { schraderi }\left[{ }^{*}\right]\end{array}$ & & & & & & & $\begin{array}{r}1 \\
<1 \\
\end{array}$ & 1 & & & \\
\hline Total specimens & 170 & 300 & 300 & 150 & 0 & 350 & 300 & 100 & 300 & 300 & 300 \\
\hline
\end{tabular}

Figure 4. Miocene silicoflagellates from Cores 7 to 13 of DSDP Hole $391 \mathrm{~A}$ and from Cores 5 and 6 of DSDP Hole $394 A$ recorded as per cent of total specimens counted. [*] = fragmented specimens probably reworked from upper Oligocene or lower Miocene deposits. 
Sphenolithus heteromorphus Zone. This supports previous correlations between coccolith and silicoflagellate zonations (Bukry, 1977b). The complete Corbisema triacantha Zone appears to range from the upper Helicosphaera ampliaperta Zone to Discoaster exilis Zone of coccoliths, thus bracketing the early to middle Miocene boundary.

\section{Naviculopsis foliacea Zone (Martini, 1974; emended, Bukry, 1977a)}

To take biostratigraphic advantage of the distinctive, common, cosmopolitan species, Naviculopsis foliacea, the duration and marker species of the middle Eocene Naviculopsis foliacea Zone (proposed by Martini, 1974, for northern Europe) have been changed. Instead of using a bottom of the first Corbisema bimucronata (rare and sporadic in deep-sea cores), the first $N$. foliacea is substituted (Bukry, 1977a). Instead of using a top of the last Dictyocha spinosa, the first occurrence of Dictyocha hexacantha is substituted to obviate reworking problems and take advantage of a fairly cosmopolitan first occurrence for transoceanic correlations.

The first occurrence of Dictyocha spinosa within the newly defined zonal interval was used to separate an upper and lower subzone (Bukry, 1977a). The Dictyocha spinosa Subzone is the interval from the first $D$. spinosa to the first $D$. hexacantha. The lower subzone where $N$. foliacea occurs prior to the appearance of $D$. spinosa is herein named the Naviculopsis robusta Subzone on the basis of lower Eocene assemblages recovered at Site 390 (Figure 5). Naviculopsis robusta s. str. has not been observed in middle or upper Eocene deep-sea cores. In Core 7 at Site $390 \mathrm{~A}, N$. robusta occurs at abundances (5\% to $12 \%$ ) approximating those of $N$. constricta and $N$. foliacea.

The distinct change from a Corbisema-dominated assemblage in Core 7 to a Dictyocha and Naviculopsisdominated assemblage in Core 6 indicates a break in the record. The break is confirmed by the absence of siliceous microfossils in the coccolith ooze of Sample $390 \mathrm{~A}-6-6,118-120 \mathrm{~cm}(66 \mathrm{~m})$, suggesting a local change in phytoplankton productivity. The nature of boundary assemblages between the subzones of the $N$. foliacea Zone still has to be determined. The Dictyocha spinosa Subzone occurs, at least, as low as the Discoaster lodoensis Zone of coccoliths, the Naviculopsis robusta Subzone, at least, within the Tribrachiatus orthostylus Zone of coccoliths.

\section{SILICOFLAGELLATE TAXONOMY}

Original references prior to 1968 have been assembled and illustrated by Loeblich et al. (1968). Incertae sedis genera Macrora and Rocella are treated with silicoflagellates in this paper.

\section{Genus CANNOPILUS Haeckel, 1887}

Cannopilus depressus (Ehrenberg)

(Plate 1, Figure 1)

Halicalyptra depressa Ehrenberg, 1854, pl. 18, fig. 111. Cannopilus sphaericus Gemeinhardt, Ling, 1972, p. 149, pl. 23, fig. 8-10.

Cannopilus depressus (Ehrenberg) Locker, 1974, p. 639, pl. 4, fig. 3. Cannopilus depressus (Ehrenberg), Bukry, 1976a, p. 890.

\section{Cannopilus schulzii Deflandre in Bachmann and Ichikawa}

Cannopilus schulzii Deflandre in Bachmann and Ichikawa, 1962, p. 171.

Cannopilus schulzii Deflandre, Bukry, and Foster, 1973, p. 826, pl. 2, fig. 2.

\section{Genus CORBISEMA Hanna, 1928}

\section{Corbisema apiculata. (Lemmermann)}

Dictyocha triacantha var. apiculata Lemmermann, 1901, p. 259, pl. 10, fig. 19,20.

Corbisema apiculata (Lemmermann), Perch-Nielsen, 1975, p. 685, pl. 2 , fig. $15,16,19$; pl. 3 , fig. $19,20,24$; pl. 15, fig. 1,2 .

Corbisema apiculata (Lemmermann), Bukry, 1975b, p. 853, pl. 1, fig. 2 .

Corbisema bimucronata bimucronata Deflandre (Plate 1, Figure 2)

Corbisema bimucronata Deflandre, 1950, p. 191, fig. 174-177.

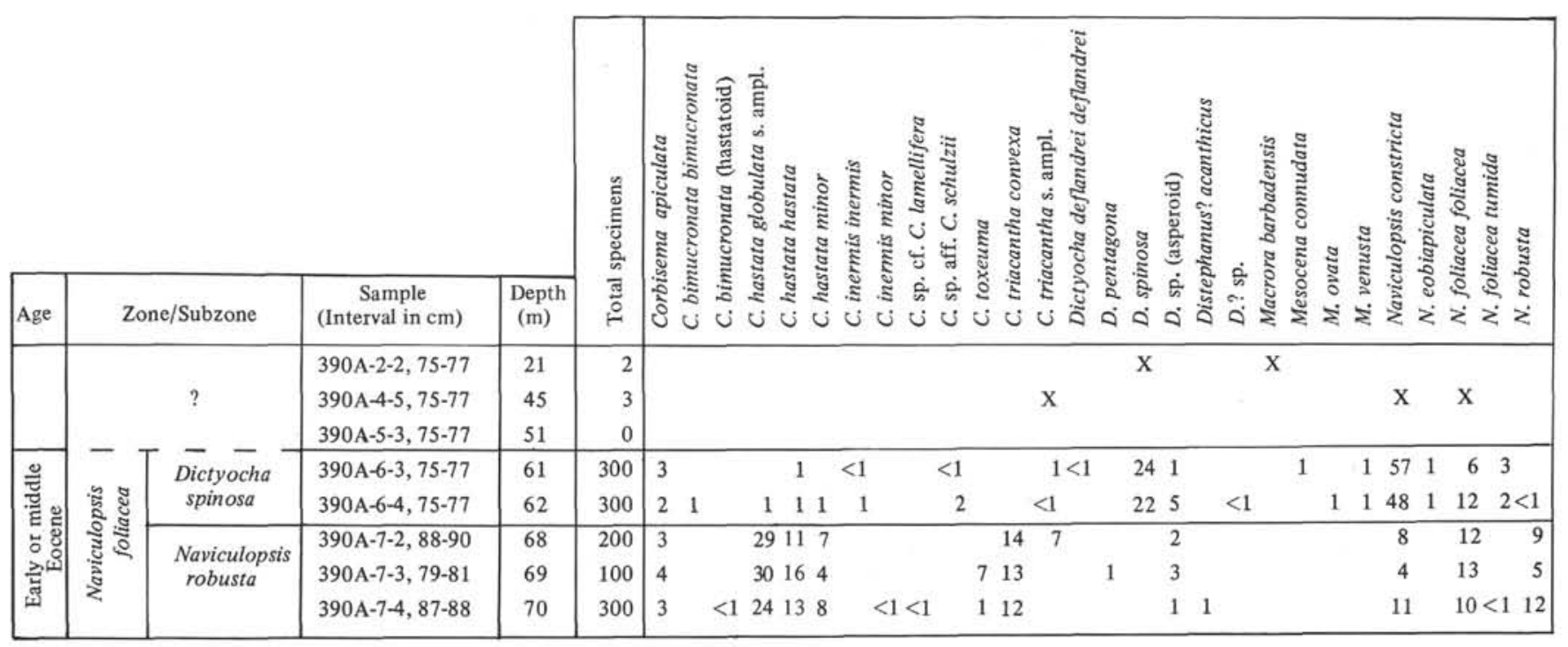

Figure 5. Eocene silicoflagellates from Cores 2 to 7 at DSDP Hole $390 \mathrm{~A}$ recorded as per cent of total specimens counted. $X=$ present, but too rare to effectively count. 
Remarks: One hastatoid variant and three typical specimens were counted in the Eocene Naviculopsis foliacea Zone assemblages at Hole $390 \mathrm{~A}$.

\section{Corbisema hastata globulata Bukry}

(Plate 1, Figures 3-5)

Dictyocha triacantha var. hastata Lemmermann, Glezer, 1966 (in part), p. 248, pl. 7, fig. 1.

Corbisema hastata globulata Bukry, 1976a, p. 892, pl. 4, fig. 1-8.

Remarks: Originally described from the upper Paleocene, Corbisema hastata globulata is common in the lower Eocene at Site 390. The specimens are short-spined, slightly scalloped, and isosceles; but are slightly larger than those of the Paleocene. Specimens with small apical plates are not uncommon.

\section{Corbisema hastata hastata (Lemmerman) \\ (Plate 1, Figures 6,7)}

Dictyocha triacantha hastata Lemmermann, 1901 , p. 259 , pl. 10 fig. 16,17.

Corbisema hastata hastata (Lemmermann), Bukry, 1976a, p. 892 , pl. 4, fig. 9-16.

Remarks: Most specimens of Corbisema hastata hastata from Leg 44 and Leg 43 in the North Atlantic are more broadly isosceles than those from Leg 36 in the South Atlantic. The size of these broader forms is similar to that of $C$. hastata globulata in the same assemblages.

\section{Corbisema hastata minor (Schulz)}

(Plate 1, Figures 8,9)

Dictyocha triacantha apiculata minor Schulz, 1928 (in part), p. 249, fig. $29 \mathrm{~b}$.

Corbisema hastata minor (Schulz), Bukry, 1975b, p. 854, pl. 1, fig. 10.

Remarks: Most specimens of Corbisema hastata minor, at Site 390 , are lopsided and distinctly isosceles in format. They are smaller than associated taxa of Corbisema (see Plate 1).

Corbisema inermis inermis (Lemmermann)

Dictyocha triacantha inermis Lemmermann, 1901, p. 259, pl. 10, fig. 21.

Corbisema inermis inermis (Lemmermann), Bukry, 1976a, p. 892, pl. 5, fig. 1-3.

Corbisema inermis minor (Glezer)

Dictyocha triacantha var. intermis f. minor Glezer, 1966, p. 247, pl. 8, fig. $3-5$; pl. 31 , fig. 7 .

Corbisema inermis minor (Glezer) Bukry, 1976a, p. 892, pl. 5, fig. 4-

\section{Corbisema sp. cf. C. lamellifera (Glezer)}

Dictyocha lamellifera var. lamellifera Glezer, 1964, p. 48, pl. 1, fig. 2 .

Remarks: A single equilateral specimen having lamellar structural elements was recorded from the lower Eocene at Site 390.

\section{Corbisema media (Glezer)}

Dictyocha elata var. media f. media Glezer, 1964, p. 51; Glezer, 1960, p. 133,134 , table 1, pl. 3 , fig. 28,29 .

Dictyocha elata var. media f. media Glezer, Glezer, 1966, p. 255, pl. 10, fig. 2,3,5

not Corbisema media (Glezer) Perch-Nielsen, 1975, p. 686, pl. 3, fig. 5,6 .

Remarks: Although Corbisema media was validly transferred, the two figured specimens (Perch-Nielsen, 1975) lack the small portals, broad structural elements, surface ornamentation, and round format of the basionym illustrated in Glezer (1966). The specimens from Perch-Nielsen (1975) can be assigned to Corbisema triacantha convexa and $C$. hastata minor (spineless variant).

Corbisema media s. str. is apparently related to the group of small robust silicoflagellates of the Eocene or Oligocene that includes such forms as Dictyocha frenguellii carentis incerta (see Glezer, 1966) and Dictyocha rotundata secta (see Glezer, 1966; Bukry, 1976b).

\section{Corbisema sp. aff. C. schulzii (Deflandre)}

Phyllodictyocha schulzii Deflandre, 1947, p. 336, fig. 2,3.

Remarks: Small angular short-spined specimens, at Site 390, that lack the distinctive complete flattening of Corbisema schulzii are tabulated as compared specimens.

\section{Corbisema toxeuma n. sp.}

(Plate 1, Figures 10-12)

Description: Corbisema toxeuma has a large, short-spined, broadly isosceles basal ring with scalloped sides and rather angular portal apices. The apical structure is simple and symmetric, composed of parallel-sided struts. The axes of the spines are alined through the center point of the apical structure. Basal pikes are missing or indistinct.

Remarks: Corbisema toxeuma is distinguished from $C$. hastata hastata (compare pl. 4, fig. 9-16, Bukry, 1976a) by having each spine axis alined through the center point of the apical structure, instead of beside the center. Also, the three central angles formed by the struts are more equant in C. toxeuma. C. toxeuma is distinguished from $C$. hastata globulata by its large size, more indented sides, and more angular portals. It is distinguished from $C$. apiculata by more elongated portals and isosceles format.

Occurrence: Corbisema toxeuma is present in the lower Eocene Naviculopsis foliacea Zone of Core 7 at DSDP Hole 390A on the Blake Plateau. Associated coccoliths belong to the Tribrachiatus orthostylus Zone.

Size: 30 to $35 \mu \mathrm{m}$, maximum internal height.

Holotype: USNM 243138 (Plate 1, Figure 11).

Isotypes: USNM 243139 and 243140.

Type locality: Blake Plateau, western North Atlantic Ocean, Sample $390 \mathrm{~A}-7-3,79-81 \mathrm{~cm}(69 \mathrm{~m})$.

\section{Corbisema triacantha convexa n. subsp.} (Plate 1, Figures 13-17)

Dictyocha triacantha fa. minor Schulz, 1928 (in part), p. 247, fig. 25b (not fig. 25a or 26).

?Corbisema triacantha var. minor (Schulz), Ling, 1972 (in part), p. 158 , pl. 24 , fig. $20-21$.

Corbisema media (Glezer), Perch-Nielsen, 1975 (in part), p. 686, pl. 3, fig. 5 (not fig. 6)

Description: Corbisema triacantha convexa has a small rounded equilateral triangular basal ring. Each side is a continuous convex curve. Spines are very short, the apices of the portals are rounded, and the symmetrically arrayed struts are slightly flared and may have a small apical plate area on some specimens.

Remarks: Corbisema triacantha convexa is distinguished from $C$. triacantha triacantha by having flared instead of parallel sided struts, and by its very short spines (compare pl. 1, fig. 13-15, Bukry, 1977b). It is distinguished from C. hastata globulata by its equilateral instead of isosceles form and by its flared struts.

To avoid confusion and ambiguity with the name Corbisema triacantha minor, the name C. triacantha convexa is used to identify the small, short-spined, convex-sided, specimens of Corbisema with flared struts, that occur in the Eocene. C. triacantha minor is restricted to small specimens similar to fig. 25a of Schulz (1928). Small size was the primary criterion of that subspecies as shown by the variety of forms illustrated.

Occurrence: Corbisema triacantha convexa is common throughout lower Eocene Naviculopsis foliacea Zone assemblages of Core 7 at DSDP Hole 390A. Associated coccoliths belong to the Tribrachiatus orthostylus Zone.

Size: 18 to $24 \mu \mathrm{m}$, maximum internal diameter.

Holotype: USNM 243141 (Plate 1, Figures 16,17).

Isotypes: USNM 243142 and 243143.

Type locality: Blake Plateau, western North Atlantic Ocean, Sample $390 \mathrm{~A}-7-4,87-88 \mathrm{~cm}(70 \mathrm{~m})$.

\section{Corbisema triacantha mediana Bukry}

Corbisema triacantha mediana Bukry, 1977b, p. 696, pl. 1, fig. 8-12. Corbisema minor (Schulz), Perch-Nielsen, 1975 (in part), p. 686, pl. 3, fig. 12 .

Corbisema triacantha (Ehrenberg), Perch-Nielsen, 1975 (in part), p. 686 , pl. 3 , fig. 11 . 
Remarks: Significant numbers of Corbisema triacantha mediana, characterized by distinctly offset apical struts, occur in the Oligocene at DSDP Site 369 in the Atlantic Ocean. Perch-Nielsen (1975) illustrated two specimens belonging to $C$. triacantha mediana from the Oligocene (DSDP Sample 277-17-4, $110 \mathrm{~cm}$ ) south of New Zealand. Use of stratigraphy can help to resolve some taxonomic problems, such as whether short- and long-spined forms of $C$. triacantha mediana (see synonymy) should be separated, but long- and shortspined forms of $C$. triacantha triacantha combined (pl. 3, fig. 15 and 16, in Perch-Nielsen, 1975). Both types of C. triacantha mediana occur in the same sample.

\section{Corbisema triacantha minor (Schulz)}

Dictyocha triacantha fa. minor Schulz, 1928 (in part), p. 247, fig. 25a and 26 (not $25 \mathrm{~b}$ ).

Corbisema triacantha var. minor (Schulz), Ling, 1972 (in part), p. 158, pl. 24, fig. $18,19,22,23$.

Corbisema minor (Schulz), Perch-Nielsen, 1975(in part), p. 686, pl. 3, fig. 7.

Remarks: Figure 25a of Schulz (1928) is herein designated the lectotype specimen of Corbisema triacantha minor.

\section{Corbisema triacantha triacantha (Ehrenberg) \\ (Plate 1, Figure 18)}

Dictyocha triacantha Ehrenberg, 1844, p. 80.

Dictyocha triacantha Ehrenberg, Lemmermann, 1901, p. 258, pl. 10, fig. 18.

Corbisema triacantha (Ehrenberg), Bukry and Foster, 1974, p. 305, fig. le.

Corbisema triacantha triacantha (Ehrenberg), Bukry, 1977b, p. 702, pl. 1,

Remarks: Corbisema triacantha s. ampl. includes simple equilateral, symmetric forms of Corbisema having moderate to long spines. Although the main range is Oligocene and Miocene, generalized specimens of Corbisema from the Eocene can also be attributed to $C$. triacantha s. ampl.

\section{Corbisema? xenica n. sp.}

(Plate 2, Figures 1-4)

Description: Corbisema? xenica is a small equilateral triangular form with convex sides and no spines. The ring is narrow and has short curved basal pikes about halfway along the sides. An apical plate fills the interring area, except for three small circular portals at the corners.

Remarks: Corbisema? xenica is distinguished from other species of Corbisema, including C. lamellifera, by its large apical plate and spineless ring. It is distinguished from possible banded analogs in genus Naviculopsis, $N$. foliacea foliacea or $N$. nordica nordica, by its triangular and spineless format.

Assignment of Corbisema? xenica to a silicoflagellate genus is queried because of its unusual form. It might be a diatom, but is provisionally classified with silicoflagellates based on the presence of basal pikes.

Occurrence: Corbisema? xenica is rare in the lower Eocene Naviculopsis foliacea Zone of Samples 390A-6-3, 75-77 cm (61 m) and $390 \mathrm{~A}-6-4,75-77 \mathrm{~cm}(62 \mathrm{~m})$, which contain Discoaster lodoensis Zone coccoliths. It is not tabulated because of its questionable affiliation.

Size: 25 to $29 \mu \mathrm{m}$ maximum diameter.

Holotype: USNM 243144 (Plate 2, Figures 1,2).

Isotype: USNM 243145.

Type locality: Blake Plateau, western North Atlantic Ocean, Sample $390 \mathrm{~A}-6-3,75-77 \mathrm{~cm}(61 \mathrm{~m})$.

\section{Genus DICTYOCHA Ehrenberg, 1837}

Dictyocha sp. aff. D. aspera (Lemmermann)

Dictyocha fibula var. aspera Lemmermann, 1901, p. 260, pl. 10, fig. 27, 28.

Remarks: Small specimens that are more equilateral than Dictyocha brevispina brevispina or $D$. pulchella, are tabulated as $D$. aspera (smail). These specimens lack noded surface ornamentation which may be a phenotypic expression.

\section{Dictyocha brevispina ausonia (Deflandre)}

(Plate 2, Figures 5-8)

Dictyocha ausonia Deflandre, 1950, p. 195, fig. 194-196, 199-202. Dictyocha brevispina ausonia (Deflandre) Bukry, 1977b,p. 697.pl. 1, fig. 17-19.

\section{Dictyocha brevispina brevispina (Lemmermann)}

(Plate 2, Figures 9,10)

Dictyocha fibula var. brevispina Lemmermann, 1901, p. 260; Ehrenberg, 1854 (in part), pl. 21, fig. 42b; pl. 22, fig. 42a,b. Dictyocha fibula var. aspera f. rhombica Schulz, 1928, p. 253, fig. 37. Dictyocha brevispina (Lemmermann) Bukry, 1976c, p. 723.

Remarks: In addition to the normal range of intraspecific variation, several unusual variants of Dictyocha brevispina brevispina are present at Site 391. Several variants, including naviculopsoid forms (Plate 2, Figures 9,10), are present.

\section{Dictyocha deflandrei deflandrei Frenguelli ex Glezer}

Dictyocha deflandrei Frenguelli, 1940 (in part), p. 65, fig. 14a,d. Dictyocha deflandrei deflandrei Frenguelli, Glezer, 1966, p. 262, pl. 12 , fig. 13,16 ; pl. 32 , fig. 4 .

\section{Dictyocha fibula fibula Ehrenberg}

(Plate 2, Figure 11)

Dictyocha fibula Ehrenberg, 1839, p. 129; Ehrenberg 1840, pl. 4, fig. 16.

Dictyocha fibula fibula (Ehrenberg), Bukry, 1977b, p. 697, pl. 2, fig. 1,2.

\section{Dictyocha pentagona Schulz}

Dictyocha fibula var. pentagona Schulz, 1928, p. 255, fig. 4la,b. Dictyocha pentagona (Schulz) Bukry and Foster, 1973, p. 827, pl. 3, fig. 10.

Dictyocha pentagona (Schulz), Bukry, 1976a, p. 894.

\section{Dictyocha pulchella Bukry \\ (Plate 2, Figures 12-16)}

Dictyocha pulchella Bukry, 1975a, p. 687 , pl. 4, fig. 1-3.

Dictyocha pulchella Bukry, 1977b, p. 704, pl. 2, fig. 3.

Remarks: Dictyocha pulchella and its deflandroid and medusoid variants (Plate 2, Figure 16) are similar to those illustrated from coeval assemblages at Sites 369 and 370 in the eastern North Atlantic (Bukry, 1977b).

\section{Dictyocha spinosa (Deflandre)}

Corbisema spinosa Deflandre, 1950, p. 193, fig. 178-182.

Dictyocha spinosa (Deflandre) Glezer, 1966, p. 256, pl. 10, fig. $6 ?, 7,8$

Dictyocha spinosa (Deflandre), Bukry, 1977a, p. 831, pl. 1, fig. 6-8.

Remarks: The oldest and most common occurrence of Dictyocha spinosa reported from DSDP cores is in Core 6 at Hole 390 A (Figure 5). D. spinosa constitutes $22 \%-24 \%$ of the assemblage which is associated with coccoliths of the Discoaster lodensis Zone.

\section{Genus DISTEPHANUS Stöhr, 1880}

\section{Distephanus? acanthicus n. sp.} (Plate 3, Figures 1-3)

Description: Distephanus? acanthicus has a large many (greater than six spines) spined basal ring, the holotype being ninespined. The spines are long and tapering, producing a concave interspine periphery. The apical structure is composed of five major struts that join irregularly in the manner of Distephanus pseudofibula or Dictyocha pentagona. These major struts bifurcate near their junctions with the basal ring to form small polygonal portals. Basal pikes are missing.

Remarks: Distephanus? acanthicus is distinguished from Distephanus polyactis by the absence of an apical ring and the presence of bifurcating struts and small portals near the basal ring (Figure 6). It is distinguished from Distephanus pseudofibula by the bifurcated struts and multispined format. Assignment to Distephanus? 


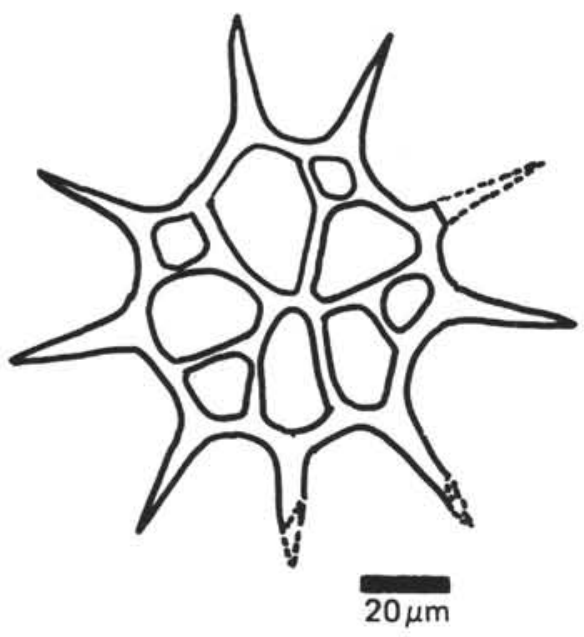

Figure 6. Tracing of holotype of Distephanus? acanthicus.

is queried because of large size and a general absence of many spined Distephanus in the Eocene.

Occurrence: Distephanus? acanthicus and its fragments are rare in the lower Eocene Naviculopsis foliacea Zone at Site 390 on the Blake Plateau. Associated coccoliths belong to the Tribrachiatus orthostylus Zone.

Size: $70 \mu \mathrm{m}$, maximum internal diameter.

Holotype: USNM 243146 (Plate 3, Figures 1,2)

Isotype: USNM 243147.

Type locality: Blake Plateau, western North Atlantic Ocean, Sample $390 \mathrm{~A}-7-4,87-88(70 \mathrm{~m})$.

\section{Distephanus boliviensis major (Frenguelli)}

Dictyocha boliviensis Frenguelli, 1940 (in part), p. 44, fig. 4b-d. Dictyocha boliviensis var. major Frenguelli, 1951, p. 277, fig. 3a-c. Cannopilus binoculus (Ehrenberg) Lemmermann, Bukry, and Foster, 1973, p. 1, fig. 1,2 .

Cannopilus major (Frenguelli) Bukry and Foster, 1973, p. 826, pl. 1, fig. $4-7$; pl. 7 , fig. 2 .

Distephanus boliviensis var. binoculus (Frenguelli) Ciesielski, 1975, p. 660 , pl. 8 , fig. 6,7. (Invalid basionym, ICBN Art. 38, fide Loeblich et al., 1968).

Distephanus boliviensis major (Frenguelli) Ciesielski, 1975, p. 660, pl. 8 , fig. 1-5.

Distephanus boliviensis major (Frenguelli), Bukry, 1975a, p. 688.

Remarks: All specimens of the Distephanus boliviensis group having large subdivided apical structures are tabulated as $D$. boliviensis major.

\section{Distephanus crux crux Ehrenberg}

(Plate 3, Figures 4,5)

Dictyocha crux Ehrenberg, 1840, p. 207; Ehrenberg, 1854, pl. 18, fig. 56 ; pl. 20 (1), fig. 46 ; pl. 33 (15), fig. 9 ; pl. 33 (16), fig. 9 ; pl. 33 (17), fig. 5 .

Dictyocha crux f. parva Bachmann in Ichikawa et al., 1967, p. 156, pl. 4, fig. 14-31.

Distephanus trigonus Uchio, 1974, p. 249, pl. 4, fig. 8,9.

Distephanus crux (Ehrenberg), Locker, 1974 (in part), p. 637, pl. 3, fig. 8, (not fig. 10).

Distephanus crux (Ehrenberg), Bukry, 1977b, p. , pl. 2, fig. 7-9.

Remarks: Several Miocene specimens of Distephanus crux crux? have unusual apical rings nearly the size of their basal ring, which approaches associated Mesocena elliptica in size and shape. These are tabulated as D. crux crux? [elliptica-like] for Core 13 of Hole 391A which also contains the greatest numbers of M. elliptica at Hole 391A (see Plate 3, Figures 6-11)

One triangular variant of Distephanus crux crux was observed (Plate 3, Figure 5); see also Ling (1971, pl. 1, fig. 8,9), Uchio (1974, pl. 4, fig. 8,9). and Ciesielski (1975, pl. 3, fig. 7).

\section{Distephanus crux darwinii Bukry}

Distephanus crux darwinii Bukry, 1976a, p. 895, pl. 7, fig. 4-13. Distephanus crux darwinii Bukry, Bukry, 1976b, p. 848, pl. 1, fig. 13,14 .

Distephanus crux loeblichii n. subsp.

(Plate 3, Figures 12,13; Plate 4, Figures 1-6)

Distephanus crux (Ehrenberg), Perch-Nielsen, 1975 (in part), p. 687, pl. 6 , fig. 1-5,7.

Description: Distephanus crux loeblichii has a moderate to large, rounded, sometimes nearly circular basal ring with small or missing pikes. Spines are short to moderate and approximately equant. The apical ring is typically moderate to large.

Remarks: Distephanus crux loeblichii is distinguished from typical Miocene Distephanus crux crux of Ehrenberg (1854) and Locker (1974), which have straight sided and commonly elongate basal rings, by its rounded ring and equant spines. It is distinguished from the other typical cruxoid Miocene taxon $D$. crux parva of Bachmann (in Ichikawa et al., 1967) by its large size, more equant spines, and less elliptic form.

Occurrence: Distephanus crux loeblichii is most common in Oligocene assemblages of DSDP Sites 280 and 328 from the Southern Ocean. It is missing in the younger Miocene assemblages of Site 391 and may be useful for stratigraphic and paleoecologic studies.

Size: 35 to $60 \mu \mathrm{m}$, maximum internal diameter.

Holotype: USNM 243148 (Plate 3, Figures 12,13).

Isotypes: USNM 243149 to 243151.

Type locality: Argentine Basin, South Atlantic Ocean, Sample $328 \mathrm{~B}-4-3,60-62 \mathrm{~cm}(40 \mathrm{~m})$.

\section{Distephanus longispinus (Schulz) (Plate 4, Figures 7,8)}

Distephanus crux f. longispina Schulz, 1928, p. 256, fig. 44. Distephanus crux var. longispina Schulz, Bachmann, 1970, p. 287, pl. 4, fig. 12-17; pl. 5, fig. 1-9.

Distephanus crux var. longispina Schulz, Ling, 1972, p. 165, pl. 26 , fig. 17-19.

Distephanus longispinus (Schulz) Bukry and Foster, 1973, p. 828, pl. 4, fig. 7,8 .

Distephamus longispinus (Schulz), Bukry, 1977b, p. 697

Remarks: Compared specimens lack spines that are longer than the greatest diameter of the basal ring.

\section{Distephanus polyactis (Ehrenberg)}

Dictyocha polyactis Ehrenberg, 1839, p. 129; Ehrenberg, 1854, pl. 22, fig. 50 .

Distephanus polyactis (Ehrenberg), Locker, 1974, p. 637, pl. 4, fig. 2.

\section{Distephanus schauinslandii Lemmermann}

(Plate 4, Figures 9,10)

Distephanus schauinslandii Lemmermann, 1901, p. 262, pl. 11 , fig. 4,5 .

Distephanus crux var. longispina Schulz, Bachmann, 1971 (in part), p. 65 , pl. 4 , fig. 8 .

Distephanus schauinslandii Lemmermann, Ling, 1973, p. 753, pl. 2, fig. 7-9.

Distephanus schauinslandii Lemmermann, Bukry, 1977b, p. 697.

\section{Distephanus speculum haliomma (Ehrenberg)}

Dictyocha haliomma Ehrenberg, 1844, p. 64, 80; Ehrenberg, 1854, pl. 21, fig. 46.

Dictyocha haliomma Ehrenberg, Locker, 1974, p. 641, pl. 4, fig. 8.

Distephanus speculum haliomma (Ehrenberg) Bukry, 1977b, p.697, pl. 2, fig. 10.

\section{Distephanus speculum hemisphaericus (Ehrenberg)}

Cannopilus hemisphaericus (Ehrenberg), Lemmermann, 1901, p. 268, pl. 11, fig. 21 .

Cannopilus hemisphaericus (Ehrenberg), Locker, 1974 (in part), p. 639 , pl. 4 , fig. 1 . 
Distephanus speculum hemisphaericus (Ehrenberg), Bukry, 1977b, p. 697 , pl. 2, fig. 11-13.

\section{Distephanus speculum pentagonus Lemmermann}

Distephanus speculum var. pentagonus Lemmermann, 1901, p. 264 , pl. 11, fig. 19.

Distephanus speculum pentagonus Bukry, 1976a, p. 895.

Distephanus speculum polyommata (Schulz) n. comb.

Cannopilus hemisphericus f. polyommata Schulz, 1928, p. 268, 278; fig. $64 \mathrm{a}, \mathrm{b}$.

Remarks: Distephanus speculum polyommata is distinguished from $D$. speculum hemisphaericus s. str. by the larger number of apical openings. The openings may not be as regularly arranged as in $D$. speculum hemisphaericus.

Distephanus speculum quintus (Bukry and Foster)

Cannopilus quintus Bukry and Foster, 1973, p. 826, pl. 1, fig. 8,9; pl. 2, fig. 1.

Distephanus speculum quintus (Bukry and Foster) Bukry, 1975b, p. 855 .

Distephanus speculum quintus (Bukry and Foster), Bukry, in press, p. 2 , fig. 12.

\section{Distephanus speculum speculum (Ehrenberg)}

Dictyocha speculum Ehrenberg, 1839, p. 150; Ehrenberg, 1854, pl. 18 , fig. 57 ; pl. 19 , fig. 41 ; pl. 21 , fig. 44 ; pl. 22 , fig. 47.

Distephamus speculum (Ehrenberg), Locker, 1974, p. 638, pl. 3, fig. $1-4,7,11$ ?

\section{Distephanus speculum triommata (Ehrenberg)}

Dictyocha triommata Ehrenberg, 1845, p. 56,76; Ehrenberg, 1854, pl. 33 (XV), fig. 11.

Dictyocha triommata Ehrenberg, Locker, 1974, p. 639, 643; pl. 4, fig. 5 .

Distephanus speculum triommata (Ehrenberg) Bukry, 1976a, p. 896.

\section{Distephanus staurodon (Ehrenberg)}

Dictyocha staurodon Ehrenberg, 1844, p. 80; Ehrenberg, 1854, pl. 18, fig. 58 .

Dictyocha staurodon Ehrenberg, Locker, 1974, p. 637, pl. 3, fig. 10. Distephanus staurodon (Ehrenberg) Bukry, 1977b, p. 697.

\section{Distephanus stradneri (Jerković)}

(Plate 5, Figure 1)

Dictyocha schauinslandii stradneri Jerković, 1965, p. 3, pl. 2, fig. 2; in Stradner 1961, fig. 90.

Distephanus schauinslandii stradneri Jerković, Bukry, 1975b, p. 866 , pl. 4 , fig. 7 .

Distephanus stradneri (Jerković) Bukry, 1977b, p. 698.

Remarks: Although the Leg 44 compared specimens are quadrate and straight-sided, there is some variation in the size and form of the apical ring.

\section{Distephanus trioctus n. sp.}

(Plate 5, Figures 2,3)

Description: Distephanus trioctus has a bilaterally symmetric, eight-spined basal ring with straight or slightly concave sides. Spines are moderate to long and there are no apparent basal pikes. The apical structure is basically a large angular triad of two equant and one slightly larger apical openings arrayed about a central point. The eight distal corners of the triad are connected directly to the interspine sides of the basal ring by eight short simple struts.

Remarks: Distephanus trioctus is distinguished from eight-spined Cannopilus schulzii (see Bukry, 1977b) by the direct connection of the apical triad to the basal ring instead of through intervening apical openings.

Occurrence: Distephanus trioctus is sparse $(3 \%)$ in the middle or lower Miocene Corbisema triacantha Zone at Well OCS-CAL 75-701 , in Sample 749-840 (lat $32^{\circ} 26^{\prime} 05^{\prime \prime} \mathrm{N}$, long $118^{\circ} 59^{\prime} 49^{\prime \prime} \mathrm{W}$, depth 109 $\mathrm{m})$. Some associated species include Corbisema triacantha, Distephanus crux hannai, and D. speculum hemisphaericus. D. trioctus is missing in coeval assemblages from Sites 391 and 394.

Size: 25 to $30 \mu \mathrm{m}$, maximum internal diameter.

Holotype: USNM 243152 (Plate 5, Figures 2,3).
Type locality: Southern California Borderland, Well OCS-CAL 75-70-1, Sample 749-840.

\section{Distephanus? sp.}

(Plate 5, Figure 4)

Remarks: A single aberrant specimen having rounded basal ring, multiple apical opening, and a few short spines is present in lower Eocene Sample 390A-6-4, 75-77 cm (62 m).

\section{Genus MACRORA Hanna, 1932}

\section{Macrora barbadensis (Deflandre)}

(Plate 5, Figure 5)

Pseudorocella barbadensis Deflandre, 1938 (in part), p. 91, fide Loeblich et al., 1968, p. 139, pl. 33, fig. 4-13,15-19 (not 14).

Pseudorocella barbadensis Deflandre, Bukry and Foster, 1974, p. 307, fig. $2 \mathrm{f}$.

Macrora barbadiensis (Deflandre) Bukry, 1977a, p. 832, pl. 2, fig. 38

Remarks: A single specimen was observed in middle Eocene Sample $390 \mathrm{~A}-2-2,75-77 \mathrm{~cm}(21 \mathrm{~m})$. This occurrence in the upper Nannotetrina quadrata Zone of coccoliths is near the typical first occurrence level of Macrora barbadensis in the western North Atlantic Ocean (Bukry, in press).

\section{Genus MESOCENA Ehrenberg, 1843}

Mesocena apiculata apiculata (Schulz)

Mesocena oamaruensis apiculata Schulz, 1928, p. 240, fig. 11.

Mesocena apiculata (Schulz), Bukry, 1975b (in part), p. 856, pl. 5, fig. 6,9 (not 7,8$)$.

\section{Mesocena apiculata curvata Bukry}

(Plate 5, Figures 6,7)

Septamesocena apiculata (Schulz), Perch-Nielsen, 1975 (in part), p. 689 , pl. 10 , fig. 6

Mesocena apiculata (Schulz), Bukry, 1975b (in part), p. 856, pl. 5, fig. 7.

Mesocena apiculata curvata Bukry, 1976b, p. 849, pl. 2, fig. 15,16.

\section{Mesocena apiculata glabra (Schulz}

Mesocena polymorpha var. triangula fa. glabra Schulz, 1928, p. 237, fig. $3 \mathrm{~b}$ ?, $3 \mathrm{c}$

Mesocena apiculata glabra (Schulz) Bukry, 1977b, p. 698, pl. 2, fig. 14,15

\section{Mesocena connudata Bukry}

(Plate 5, Figure 8)

Mesocena? connudata Bukry, in press, pl. 3, fig. 4,5.

\section{Mesocena diodon diodon Ehrenberg}

(Plate 5, Figures 9-13)

Mesocena diodon Ehrenberg, 1844, p. 71, 84; Ehrenberg, 1854, pl. 33 (15), fig. 18.

Mesocena cf. elliptica Ehrenberg, Ling, 1972 (in part), p. 177, pl. 28 , fig. 11.

Mesocena diodon Ehrenberg, Bukry and Foster, 1973 (in part), p. 828 , pl. 6 , fig. 6 (not fig. 7)

Bachmannocena diodon (Ehrenberg) Locker, 1974, p. 636, pl. 2, fig. 9 .

Remarks: Ehrenberg's (1854) figured type specimen is a smooth form that is associated with lower or middle Miocene taxa such as Corbisema triacantha and the diatom Craspedodiscus coscinodiscus. Locker's (1974) lectotype is also smooth instead of noded. Noded specimens of Mesocena diodon having more robust spines are typical of upper Miocene or Pliocene. Such specimens are herein designated Meoscena diodon nodosa.

Mesocena diodon nodosa $n$. subsp.

(Plate 5, Figures 14,15; Plate 6, Figures 1-5)

Mesocena crenulata var. diodon (Ehrenberg) Lemmermann, 1901, p. 855 , pl. 10 , fig. 1,2

Mesocena crenulata var. diodon (Ehrenberg), Schulz, 1928, p. 236, fig. la,b.

Mesocena crenulata var. diodon (Ehrenberg), Gemeinhardt, 1930 (in part), p. 27, fig. 10a (not fig. 10b, which is septate). 
Mesocena cf. elliptica Ehrenberg, Ling, 1970 (in part), p. 100, pl. 20, fig. 8,9 (not 10-14).

Mesocena cf. elliptica Ehrenberg, Ling, 1972 (in part), p. 177, p. 28, fig. 9, 10? (not 11, not 12-15).

Mesocena diodon Ehrenberg, Bukry and Foster, 1973 (in part), p. 828 , pl. 6 , fig. 7 (not fig. 6).

Mesocena diodon Ehrenberg, Bukry, 1973c, p. 830, pl. 3, fig. 4,5.

Mesocena cf. elliptica Ehrenberg, Ling, 1973 (in part), p. 753, pl. 3, fig. 1,2 .

Mesocena diodon Ehrenberg, Bukry, 1973d, p. 866, pl. 2, fig. 6,7.

Mesocena diodon Ehrenberg, Ciesielski, 1975, p. 661, pl. 12, fig. 1-3.

Mesocena diodon Ehrenberg, Bukry, 1975b, p. 868, pl. 6, fig. 3 .

Mesocena sp. cf. $M$. diodon Ehrenberg, Bukry, 1976d, p. 698, pl. 2, fig. 2 .

Description: Mesocena diodon nodosa has a circular to elongate oval ring with two prominent distal spines alined with the major axis. The surface is ornamented with small, blunt and pointed nodes. Although usually unpatterned, the nodes may occur in circlets on cold-water forms (see Bukry, 1973d and Ciesielski, 1975). Distally directed nodes are larger than the proximal nodes; the inner margin of the ring is rather smooth.

Remarks: Mesocena diodon nodosa is distinguished from $M$. diodon diodon by a noded surface that is obvious in routine ( 200 to $500 \times$ ) light microscopy. The spines are larger. M. diodon nodosa is distinguished from M. elliptica $\mathrm{s}$. str. by its noded surface and twospined shape, and from $M$. quadrangula by its two-spined shape.

Occurrence: Mesocena diodon nodosa is most common in the upper Miocene and lower Pliocene of high-latitude localities (DSDP Legs 19 and 28). It may have developed directly from smooth forms of $M$. diodon diodon during the middle Miocene or from associated noded and apiculate forms of $M$. circulus or $M$. quadrangula.

Because noded Mesocena diodon is considered a distinct entity (Ciesielski, 1975) and not simply a sporadic variant of $M$. elliptica or $M$. quadrangula, the distinction of relatively smooth $M$. diodon diodon from $M$. diodon nodosa helps to reflect a general evolutionary trend in Mesocena. Early Miocene and older members of Mesocena from deep-sea sites are relatively smooth. The development of prominent surface nodes occurred in the middle and late Miocene for most members of the genus.

Size: 40 to $75 \mu \mathrm{m}$, maximum internal diameter.

Holotype: USNM 243153 (Plate 5, Figures 14,15).

Isotypes: USNM 243154 to 243158.

Type locality: Meiji Guyot, Emperor Seamounts, northwestern North Pacific Ocean, Sample 192-13-2, 69-70 cm (233 m).

\section{Mesocena elliptica (Ehrenberg)}

\section{(Plate 6, Figures 6-13)}

Dictyocha (Mesocena) elliptica Ehrenberg, 1840, p. 208; Ehrenberg, 1854, pl. 20 (1), fig. $44 a$,b.

Mesocena polymorpha var. quadrangula (Ehrenberg), Schulz, 1928 (in part), p. 237, fig. $4 b$, (not $4 a, c)$.

Mesocena elliptica minoriformis Bachmann and Papp, 1968, p. 121, pl. 3 , fig. 9 .

?Mesocena elliptica elliptica Ehrenberg, Bachmann and Papp, 1968, pl. 3, fig. 12 .

Mesocena elliptica var. minoriformis Bachmann and Papp, Bachmann, 1971 , p. 556 , pl. 1 , fig. $5-8$

Mesocena cf. elliptica var. minoriformis Bachmann and Papp, Ling, 1972, p. 178, pl. 29, fig. 4-7.

Mesocena elliptica Ehrenberg, Locker, 1974, p. 634, pl. 2, fig. 4.

Mesocena sp. cf. M. elliptica var. minoriformis Bachmann and Papp, Ling, 1975, p. 772, pl. 2, fig. 9,10.

Remarks: The original figures of Mesocena elliptica shown by Ehrenberg (1854) and the lectotype selected by Locker (1974) are all small smooth elliptic to rounded rhomboid forms that occur with Naviculopsis navicula, a characteristic lower Miocene species. The subspecies $M$. elliptica minoriformis illustrated by Bachmann and Papp (1968) and Bachmann (1971) appears to be conspecific because it is also a small $(30-50 \mu \mathrm{m})$ smooth rounded form that occurs in the lower Miocene of Austria with $N$. navicula s. ampl. The ratio of basal ring major axes for Bachmann's (1971) N. navicula and M. elliptica minoriformis is 1.6 to 1.8. The same ratio for Ehrenberg's and Locker's specimens is 1.8 to 1.9, and major axis length for Locker's lectotype is $47 \mu \mathrm{m}$, excluding spines. Therefore, stratigraphic and morphologic considerations indicate that $M$. elliptica minoriformis is a junior synonym $M$. elliptica elliptica s. str.
Whether a separation of large and small forms into taxonomic categories is necessary (see Bachmann and Papp) for stratigraphic or paleoecologic purposes is not clear. If such distinction proves worthwhile, then a new name for large forms would be required.

Recognition that the name Mesocena elliptica is based on smooth, fairly rounded forms from the lower or middle Miocene means that the name Mesocena quadrangula Ehrenberg ex Haeckel should be given priority for the noded, and generally more rhomboid specimens of the Miocene to Quaternary.

The youngest major population of Mesocena elliptica is reported by Ling (1975) from the early Pliocene of the Sea of Japan.

\section{Mesocena ovata Bukry}

(Plate 7, Figure 6)

Mesocena ovata Bukry, in press, pl. 3, fig. 6.

\section{Mesocena quadrangula Ehrenberg ex Haeckel (Plate 7, Figures 1-5)}

Mesocena quadrangula Ehrenberg ex Haeckel, 1887, p. 1556; Lemmermann, 1901, pl. 10, fig. 5-7; fide Loeblich et al., 1968, p. 57.

?Mesocena crenulata var. elliptica (Ehrenberg), Schulz, 1928, p. 236, fig. 2.

Mesocena polymorpha var. quadrangula (Ehrenberg), Schulz, 1928 (in part), p. 237, fig. 4a,c, (not 4b)

Mesocena polymorpha var. quadrangula (Ehrenberg), Gemeinhardt, 1930 , p. 29 , fig. 13.

Mesocena elliptica Ehrenberg, Bachmann and Ichikawa, 1962 (in part), p. 167 , pl. 1 , fig. $1,2,4,6,8,9 ?, 10$ ?.

Mesocena cf. elliptica Ehrenberg, Ling, 1970 (in part), p. 100, pl. 20 , fig. 10-14, (not 8,9).

Mesocena quadrangula Ehrenberg ex Haeckel, Martini, 1971, p. 1696 , pl. 1 , fig. 2 .

Mesocena elliptica verrucosa Dumitricà, 1973a, p. 878, pl. 17, fig. 2. Mesocena elliptica elliptica Ehrenberg, Dumitricǎ, 1973b, p. 904 , pl. 3 , fig. 4 .

Mesocena elliptica verrucosa Dumitrică, $1973 \mathrm{~b}$ (in part), p. 905, pl. 1, fig. 1,2, 4-6; pl. 2, fig. 1-3,5; pl. 3, fig. 1,3,5,6.

Mesocena cf. elliptica Ehrenberg, Ling, 1973 (in part), p. 753, pl. 3, fig. 3,4 , (not 1,2 ).

Mesocena sp. cf. M. elliptica Ehrenberg, Ling, 1975, p. 772, pl. 1, fig. 8 .

Mesocena elliptica Ehrenberg, Bukry, 1977b, p. 704, pl. 2, fig. 16. Remarks: Restriction of the name Mesocena elliptica to smal smooth specimens that are most common in the Miocene, means that $M$. quadrangula is the earliest available name for the noded and typically rhomboid quadrate Mesocena specimens which are most common in the upper Miocene to Quaternary.

\section{Mesocena triangula (Ehrenberg)}

Mesocena triangula (Ehrenberg) 1844, p. 65, 71; Ehrenberg, 1854, p. 22 , fig. 41 .

Mesocena polymorpha var. triangula (Ehrenberg), Schulz, 1928 (in part), p. 237, fig. 3a (not fig. 3b,c)

?Bachmannocena triangula (Ehrenberg) Locker, 1974, p. 636, pl. 2, fig. 10 (lectotype)

Remarks: Although a regular triangular form having a noded surface and spines is considered the basic form of this species (see Schulz, 1928, fig. 3a), Ehrenberg's figure is not equilateral. Locker's lectotype is unfortunately equivocal, a possible variant of several different species. It is an inappropriate match to Ehrenberg's figure which is more clearly triangular.

\section{Mesocena triodon Bukry \\ (Plate 7, Figures 9,10)}

not Mesocena triangula Ehrenberg, 1840, p. 208; Ehrenberg, 1854, pl. 22, fig. 41 .

Mesocena polymorpha var. triangula (Ehrenberg) Lemmermann, 1901 , p. 255 , pl. 10 , fig. 3,4 .

Mesocena polymorpha var. triangula (Ehrenberg), Gemeinhardt, 1930 (in part), p. 28, fig. 12c (not fig. 12a,b)

Mesocena elliptica Ehrenberg, Bachmann and Ichikawa, 1962 (in part), p. 167 , pl. 1 , fig. 3,10 ?

Mesocena triodon Bukry, 1973d, p. 860, pl. 2, fig. 11

not Septamesocena sp. Perch-Nielsen, 1975, p. 690, pl. 10, fig. 11 (septate). 
Remarks: Mesocena triodon is distinguished from $M$. triangula by having two of its three spines alined on the same axis. The ring lacks the regular triangular symmetry of $M$. triangula; it is more oval or circular. The alinement of two spines in $M$. triodon also distinguishes it from nonsymmetric three-spined variants of $M$. quadrangula.

The type specimen of Mesocena triodon is noded. Smooth forms from the lower or middle Miocene are not separated out because the sparse and sporadic occurrence of the species gives it little significance.

\section{Mesocena venusta Bukry \\ (Plate 7, Figures 7,8)}

Mesocena venusta Bukry, 1977a, p. 832, pl. 1, fig. 11-13. Mesocena venusta Bukry, Bukry, in press, pl. 3, fig. 7,8.

\section{Genus NAVICULOPSIS Frenguelli, 1940}

\section{Naviculopsis biapiculata (Lemmermann)}

Dictyocha navicula biapiculata Lemmermann, 1901, p. 258, pl. 10, fig. $14 ?, 15$.

Dictyocha regularis Carnevale, 1908, p. 35, pl. 4, fig. 28.

Naviculopsis regularis (Carnevale), Ling, 1972 (in part), p. 188, pl. 31, fig. 5 (not fig. 3,4).

Naviculopsis biapiculata (Lemmermann) s.l., Dumitricà, 1973 (in part), p. 847 , pl. 1 , fig. 4 .

Naviculopsis biaiculata s.l. (Lemmermann), Perch-Nielsen, 1975 (in part), p. 689 , pl. 12 , fig. 19

Naviculopsis cf. N. lata (Deflandre), Perch-Nielsen, 1975 (in part), p. 689 , pl. 12 , fig. $9,10 ?, 11,13,14$.

Naviculopsis trispinosa (Schulz), Perch-Nielsen, 1975 (in part), p. 689 pl. 12, fig. 4.

Naviculopsis biapiculata (Lemmermann), Bukry, 1975b (in part), p. 856 , pl. 6 , fig. $5,7,8$.

Naviculopsis biapiculata (Lemmermann), Ciesielski, 1975, p. 661, pl. 12, fig. 9?,10,11.

Naviculopsis biapiculata (Lemmermann), Bukry, 1975c, p. 720, pl. 3, fig. 2 .

\section{Naviculopsis constricta (Schulz)}

Dictyocha navicula biapiculata constricta Schulz, 1928, p. 246, fig. 21 Naviculopsis constricta (Schulz), Ling, 1972, p. 183, pl. 30, fig. 5-8. Naviculopsis cf. N. lata (Deflandre), Perch-Nielsen, 1975 (in part), p. 689 , pl. 12 , fig. 12 .

Naviculopsis constricta (Schulz), Perch-Nielsen, 1975, p. 689, pl. 12, fig. $16,17,23$.

Naviculopsis constricta (Schulz), Bukry, 1976a, p. 897, pl. 9, fig. 1,2.

\section{Naviculopsis eobiapiculata Bukry}

(Plate 7, Figure 11)

not Dictyocha navicula biapiculata Lemmermann, 1901, p. 258 , pl. 10, fig. 14?,15.

not Dictyocha regularis Carnevale, 1908, p. 35, pl. 4, fig. 28.

Naviculopsis biapiculata (Lemmermann) s. I. Dumitricá, 1973c (in part), p. 847 , pl. 1, fig. $5,9,10$ ?.

Naviculopsis regularis (Carnevale), Ciesielski, 1975, p. 662, pl. 13, fig. 4 ?,5?,6,7

Naviculopsis eobiapiculata Bukry, in press, pl. 4, fig. 9-16.

\section{Naviculopsis foliacea foliacea Deflandre}

(Plate 7, Figure 12)

Naviculopsis foliacea Deflandre, 1950, p. 204, fig. 235-240.

Naviculopsis foliacea Deflandre, Ling, 1972, p. 184, pl. 30, fig. 9-11. Naviculopsis foliacea Deflandre, Bukry, 1975b, p. 856.

Naviculopsis foliacea Deflandre, Bukry, 1976b, p. 849, pl. 2, fig. 11.

Naviculopsis foliacea tumida n. subsp.

(Plate 8, Figures 1-8; Plate 17, Figures 11, 12)

Description: Naviculopsis foliacea tumida has a small oval basal ring that is largely covered by a high arched apical band. Two small rounded portals pierce the ends of the band. Each portal occupies only $8 \%$ to $22 \%$ ( $15 \%$ mean) of the ring length. Because of the high arch of the band the portal is directed nearly perpendicular to the adjacent spine. A flange may occur within the basal ring in the manner of $N$. foliacea foliacea (see Bukry, 1973e, pl. 1, fig. 6,7). The major/minor axis ratio of the basal ring is approximately $2 / 1$. Spines are typically slightly shorter than the basal ring ( $72 \%$ to $95 \%$ as long); one specimen of the seven studied has longer spines.

Remarks: Naviculopsis foliacea tumida is distinguished from $N$. foliacea foliacea by its smaller, wider basal ring, smaller portals, and higher band. It is distinguished from $N$. nordica nordica by its more oval basal ring and relatively longer spines. It is distinguished from $N$. constricta by its rounded basal ring, flange, and small portals.

Occurrence: Naviculopsis foliacea tumida is present in the lower Eocene Naviculopsis foliacea Zone at Site 390. It is most common (2\% to $3 \%$ ) in the Dictyocha spinosa Subzone of Hole 390A Core 6.

Size: 25 to $38 \mu \mathrm{m}$, maximum internal diameter.

Holotype: USNM 243159 (Plate 8, Figures 1,2).

Isotypes: USNM 243160 to 243165 .

Type locality: Blake Plateau, western North Atlantic Ocean, Sample 390A-6-3, 75-77 cm (61 m).

\section{Naviculopsis lata (Deflandre) \\ (Plate 9, Figures 1, 2; Plate 19, Figure 16)}

Dictyocha biapiculata lata Deflandre, 1932, p. 500, fig. 30,31. Naviculopsis lata (Deflandre) Frenguelli, 1940, p. 61, fig. $11 \mathrm{~h}$. Naviculopsis robusta Deflandre, Stradner, 1961, p. 89, pl. 2, fig. 39$43,44 ?, 45$.

Naviculopsis robusta Deflandre, Bachmann and Papp, 1968, pl. 3, fig. 3,4 .

Naviculopsis lata (Deflandre), Bachmann, 1970, p. 278, text-fig. 1a, b; pl. 2, fig. 1-19; pl. 3, fig. 1-9, 10?, 11-15.

Naviculopsis lata (Deflandre), Martini, 1972, text-fig. 1.

Naviculopsis lata (Deflandre), Ling, 1972, p. 185, pl. 30, fig. 12-16.

?Naviculopsis regularis (Carnevale), Ling, 1972 (in part), p. 188, pl. 31 , fig. 4 .

Naviculopsis lata (Deflandre), Bukry, 1973d, p. 866, pl. 2, fig. 12.

Naviculopsis lata (Deflandre), Bukry and Foster, 1974, p. 307, fig. $2 \mathrm{~d}$.

Naviculopsis robusta Deflandre, Perch-Nielsen, 1975, p. 689, pl. 12, fig. 5,6 .

Naviculopsis lata (Deflandre), Perch-Nielsen, 1975, p. 689, pl. 12, fig. 7?, 8.

Naviculopsis lata (Deflandre), Bukry, 1975b, p. 856, pl. 7, fig. 4 .

Naviculopsis robusta Deflandre, Ciesielski, 1975, p. 662, pl. 13, fig. 8-12.

Naviculopsis lata (Deflandre), Bukry, 1977b, p. 698, pl. 3, fig. 2

Naviculopsis lata (Deflandre), Bukry, in press.

Remarks: Naviculopsis lata is a latest Oligocene or early Miocene species which is generally larger and has smaller triangular expansions at the base of the bar than does Eocene $N$. robusta. No late Eocene or early Oligocene populations are known to provide a connection between the two species, but the general form of the two species is remarkably similar.

The extremely wide, nearly hexagonal specimens illustrated from DSDP Leg 29 (Bukry, 1975b: Perch-Nielsen, 1975) may be a highlatitude form, as they are missing from other populations of Naviculopsis lata. Interestingly, Glezer (1966) illustrates a comparable wide hexagonal variant of $N$, robusta from the Eocene of the Ural Mts. This form is missing in the Eocene $N$. robusta from Site 390.

\section{Naviculopsis navicula (Ehrenberg)}

Dictyocha navicula Ehrenberg, 1839, p. 129; Ehrenberg, 1854, pl. 20 (1), fig. 43.

?Naviculopsis navicula (Ehrenberg), Stradner, 1961 (in part), p. 89, fig. 47, (not fig. 46).

Naviculopsis navicula (Ehrenberg) Locker, 1974 (in part), p. 635, pl. 2, fig. 1, (not fig. 2).

Naviculopsis navicula (Ehrenberg), Bukry, 1976a, p. 897.

Naviculopsis navicula (Ehrenberg), Bukry, 1977b, p. 706, pl. 3, fig. 3.

Remarks: Naviculopsis navicula has an unornamented basal rìng with rounded ends and equant tubular dimensions throughout, according to the lectotype figure of Locker (1974). This distinguishes it from $N$. ponticula with broader ends and short axial spines. 


\section{Naviculopsis obtusarca n. sp.}

Naviculopsis navicula (Ehrenberg) Deflandre, 1950 (in part), p. 205, fig. 241, 242 (not 243).

Naviculopsis navicula (Ehrenberg), Stradner, 1961 (in part), p. 89, pl. 2, fig. 46, (not fig. 47).

Naviculopsis navicula (Ehrenberg), Bachmann and Papp, 1968, pl. 3, fig. 5 .

Naviculopsis navicula (Ehrenberg), Bachmann, 1970 (in part), p. 282, text-fig. 2a, c-f (not b).

Naviculopsis sp. Ling, 1972, p. 189, pl. 31, fig. 6.

Naviculopsis ponticula (Ehrenberg), Bukry, 1977b, p706, pl. 3, fig. 4. Description: Naviculopsis obtusarca has a distinctive boat-shaped basal ring with blunt ends. The sides of the ring are inclined from the minor axis apical bar that is approximately twice as wide as the blunt ends. There are no axial spines and the end segment can be slightly broader than adjacent ring sides. Small spines may be developed at the corners on some specimens. Wide specimens have the sides slightly indented at the minor axis.

Remarks: Naviculopsis obtusarca is unique among species of Naviculopsis because of its blunt ends. The only other species lacking axial spines, like $N$. obtusarca is $N$. navicula which can be distinguished by its continuous rounded ends. $N$. obtusarca is also distinctive in having nonaxial spines at the ends of the blunt segment, if spines are developed. $N$. ponticula has small axial spines or vestigial swellings.

Occurrence: Naviculopsis obtusarca is reported from early Miocene or late Oligocene deposits. Ling (1972) notes it is absent from deep-sea sites in the Atlantic, Indian, and Pacific oceans. Its occurrence at DSDP Site 370 (Bukry, 1977b) in the Morocco Basin (depth $4216 \mathrm{~m}$ ) is in terrigenous-rich sediment in a relatively nearshore location.

Size: 70-85 $\mu \mathrm{m}$, maximum length (Holotype, $76 \mu \mathrm{m}$ )

Holotype: Plate 3, figure 4 of Bukry (1977b).

Isotypes: Text-figures 2a, c-f of Bachmann (1970).

Type locality: Eastern North Atlantic Ocean, Sample 370-3, CC (217 m).

\section{Naviculopsis ponticula (Ehrenberg) (Plate 8, Figures 9, 10)}

Dictyocha ponticulus Ehrenberg, 1844, p. 258, 267; Bailey, 1845, pl. 4, fig. 21 .

not Dictyocha pons Ehrenberg 1844, p. 64, 80; Ehrenberg, 1854 , pl. 21 , fig. 40.

?Dictyocha navicula var. pons (Ehrenberg) Lemmermann, 1901, p. 258 , pl. 10 , fig. $12,13$.

?Naviculopsis navicula (Ehrenberg), Deflandre, 1950 (in part), p. 205, fig. 243 (not fig. 241, 242).

Naviculopsis navicula (Ehrenberg), Martini, 1972, p. 120, text-fig. 2.

Naviculopsis navicula (Ehrenberg), Ling, 1972, p. 186, pl. 30, fig. 1719; pl. 31, fig. 1; [vestigial spines, but ends broadened and rounded].

Naviculopsis quadrata (Ehrenberg), Bukry and Foster, 1973, p. 306, fig. $2 \mathrm{e}$.

Naviculopsis navicula (Ehrenberg), Locker, 1974 (in part; lectotype illustration of Dictyocha ponticulus Ehrenberg), p. 635, pl. 2, fig. 2 (not fig. 1).

Remarks: The broadened ends bearing a small spine help distinguish Naviculopsis ponticula from $N$. navicula.

\section{Naviculopsis quadrata (Ehrenberg) (Plate 8, Figure 11)}

Dictyocha quadrata Ehrenberg, 1844, p. 258, 267; fide Loeblich et al., 1968 , p. 105, pl. 19, fig. 12 .

Dictyocha navicula rectangulare Schulz, 1928, p. 243, fig. 17a, b.

Naviculopsis rectangularis (Schulz) Frenguelli, 1940, fig. 11j, k.

Naviculopsis iberica Deflandre, 1950, p. 202, fig. 231-234

Naviculopsis iberica Deflandre, Bachmann, 1970, text-fig. 1c-f.

Naviculopsis rectangularis (Schulz), Bachmann, 1970, text-fig. 3a-f.

Naviculopsis rectangularis (Schulz), Martini, 1972, p. 120, fig. 3.

not Naviculopsis lata (Deflandre), Ling, 1972 (in part), p. 185, pl. 30, fig. 12-16; [spines are too long].

Naviculopsis quadrata (Ehrenberg), Ling 1972, p. 187, pl. 31, fig. 2

Naviculopsis quadrata pacifica Dumitrica, 1973c, p. 846, pl. 1, fig. 12-14.
Naviculopsis sp. Dumitrică, 1973c, p. 847, pl. 1, fig. 15.

Naviculopsis quadratum (Ehrenberg), Locker, 1974, p. 635, pl. 2, fig. 3 ; [lectotype].

Naviculopsis quadrata (Ehrenberg), Bukry, 1976a, p. 856.

Naviculopsis quadrata (Ehrenberg), Bukry, 1977b, p. 706, pl. 3, fig. 6-8.

Remarks: Short spines, typically less than half the length of the minor axis and an elongate $(2: 1)$ rectangular outline characterize this species. Two specimens from Leg 41 (Bukry, 1977b) that have flared spines are reminiscent of the broad rounded spines of Deflandryocha (Jerković, 1969, pl. 6 and 7) that may result from nearshore conditions (see Hajos, 1976)

\section{Naviculopsis robusta Deflandre \\ (Plate 8, Figures 12-15)}

Naviculopsis robusta Deflandre, 1950, p. 202, fig. 227-230.

not Naviculopsis robusta Deflandre, Stradner, 1961, p. 89, pl. 2 , fig. $39-43,44$ ?, 45 ,

Naviculopsis robusta Deflandre, Glezer, 1966, p. 273, pl. 16, fig. 1; pl. 33, fig. 3-6.

not Naviculopsis robusta Deflandre, Bachmann and Papp, 1968, pl. 3, fig. 3,4 .

not Naviculopsis robusta Deflandre, Perch-Nielsen, 1975, p. 689 , pl. 12, fig. 5, 6 .

not Naviculopsis robusta Deflandre, Ciesielski, 1975, p. 662, pl. 13, fig. 8-12.

Remarks: Early Eocene Naviculopsis robusta of Site 390 differ from younger $N$. lata in their somewhat smaller size and the presence of triangular plates at the ends of the apical bar. However, the great similarity in construction and proportions between the two species belies the difference in age between their respective early Eocene (5054 m.y.) and latest Oligocene (23 m.y.) occurrences.

\section{Genus ROCELLA Hanna, 1940}

\section{Rocella gelida (Mann)}

(Plate 9, Figure 3)

Strictodiscus gelidus Mann, 1907, p. 268, pl. 50, fig. 5.

Rocella gemma Hanna, 1930 (in part,) p. 415, pl. 40, fig. 1, 2, 4-9. Strictodiscus gelidus Mann, Bukry, 1976a (in part), p. 916, pl. 9, fig. 5, 6, 7 (lower), 8, 9 .

Rocella gelida (Mann) Bukry, in press, pl. 5, fig. 1-13.

\section{Rocella schraderi Bukry}

Rocella gemma Hanna, 1930 (in part), p. 415, pl. 40, fig. 3, 10, 11. Rocella gemma Hanna, Ling, 1972, p. 192, pl. 31, fig. 12-15. Rocella schraderi Bukry, in press, pl. 6, fig. 1-10; pl. 7, fig. 1.

\section{ACKNOWLEDGMENT}

I thank Dorothy Blackstock, U.S. Geological Survey, for her patience and skill in typing and proofing this manuscript. The paper was improved through critical reviews by Naja Mikkelsen, Scripps Institution of Oceanography, and John Barron, U.S. Geological Survey. Specially cleaned and mounted slides of Distephanus crux loeblichii were kindly provided by Herman Adler, Campbell, California. Slides of Southern California Borderland core samples that were used for comparisons to Leg 44 were made available by Jack Vedder, U.S. Geological Survey, and by A.D. Warren, Anderson, Warren and Associates.

\section{NOTE ADDED IN PROOF}

In correlating a new diatom zonation of the U.S. East Coast to DSDP Site 391, Abbott (1978, p. 28) attributes Cores 12 and 13 to the lower Miocene "possibly as low as Nannoplankton Zone NN 4, on the basis of information from Schmidt and/or Bukry." This information came in the form of a personal communication from Gradstein in 1977 (Abbott, 1978). My coccolith zonation for Site 391 places the upper three sections of Core 12 in the middle Miocene 
Sphenolithus heteromorphus Zone and lower Core 12 and Core 13 into the middle and lower Miocene Helicosphaera ampliaperta Zone (see Ryan et al., 1974). Technically, the $H$. ampliaperta Zone is present in the lower type Langhian (Bramlette and Wilcoxon, 1967; Martini, 1971; and Ryan et al., 1974) and if the base of the Langhian is accepted as the lower/middle Miocene boundary (Ewing et al., 1969; Berggren, 1971; and Ryan et al., 1974), then it is probable that most of Core 12 is middle Miocene, not lower Miocene.

Although Abbott reported Annellus californicus at Site 391 only from Cores 9 and 10 (Abbott, 1978, p. 28), I have noted a longer range by sparse occurrences in my prepared silicoflagellate slides from Cores 12 and 13 at Site 391; this supports his observations on the range of $A$. californicus in the Delphineis ovata Zone of the Dover well (Abbott, 1978, p. 26). My samples of Cores 10 and 12 contain sparse Naviculopsis spp. which I consider reworked on the basis of the associated silicoflagellates. However, the presence of Naviculopsis in Cores 10 and 12 clouds assignment of these cores to the $D$. ovata Zone and $D$. ovata $/ D$. penelliptica Zone because the absence of these silicoflagellates is a boundary criterion for the base of the $D$. ovata Zone (Abbott, 1978, p. 24 and 28). Because silicoflagellates are usually rare relative to diatoms, the absence of Naviculopsis and the reworked or in-place nature of any occurrence would be difficult to assess without counting an appropriate number (200 or 300) of silicoflagellates. Therefore, caution should be exercised in using silicoflagellates for the boundaries of diatom zones; the first occurrence of $D$. ovata is recommended as the boundary for the $D$. ovata Zone.

In summary, it is suggested that stratigraphic correlation for the new East Coast diatom zones not be made on the basis of reworked and, as yet, incompletely documented species ranges from the Miocene of DSDP Site 391 .

References cited in note:

Abbott, W. H., 1978. Correlation and zonation of Miocene strata along the Atlantic margin of North America using diatoms and silicoflagellates, Marine Micropaleontology, v. 3, p. 15-34.

Berggren, W.A., 1971. Tertiary boundaries and correlations. In Funnell, B.M., and Riedel, W. R. (Eds.), The micropaleontology of oceans: Cambridge (Cambridge Univ. Press), p. 693-809.

Bramlette, M.N. and Wilcoxon, J.A., 1967. Middle Tertiary calcareous nannoplankton of the Cipero Section, Trinidad, W.I.; Tulane Studies Geology, v.5, p.93-131.

Ewing, M. Worzel, J.L., Beall, A.O., Berggren, W.A., Bukry, D., Burk, C.A., Fischer, A.G., and Pessagno, E.A., Jr., 1969. Appendix I: Time stratigraphic framework: Initial Reports of the Deep Sea Drilling Project, Volume 1, p. 643-651.

Martini, E., 1971. Standard Tertiary and Quaternary calcareous nannoplankton zonation, 2nd Plankt. Conf. Proc., p. 739-785.

Ryan, W.B.F., Cita, M.B., Dreyfus Rawson, M., Burckle, L.H., and Saito, T., 1974. A paleomagnetic assignment of Neogene stage boundaries and the development of isochronous datum planes between the Mediterranean, the Pacific and Indian Oceans in order to investigate the response of the world ocean to the Mediterranean "salinity crisis," Riv. Italiana Paleontologia, v.80, p.631-688.

\section{REFERENCES}

Bachmann, A., 1970. Silicoflagellaten aus dem oberösterreichischen Egerien (Oberoligozän): Osterreichische Geol. Bundesanst. Verh., v. 2, p. 275-305. 1971. Silicoflagellaten aus dem Eggenburgien von

Ernstbrunn (Niederösterreich): Österreichische Geol. Bundesanst. Verh., v. 3, p. 552-569.

Bachmann, A. and Ichikawa, W., 1962. The silicoflagellides in the Wakura Beds, Nanao City, Prefecture Ishikawa, Japan: Kanazawa Univ. Sci. Rept., v. 8, p. 161-175.

Bachmann, A. and Papp, A., 1968. Vorkommen und verbreitung der silicoflagellaten im Neogen Österreichs: Gior. Geol., v. 35, p. 117-126.
Bailey, J.W., 1843. Notice of some new localities of Infusoria, fossil and Recent: Am. J. Sci., v. 48, p. 321-343.

Bukry, D., 1972. Coccolith stratigraphy Leg 11, Deep Sea Drilling Project. In Hollister, C.D., Ewing, J.I., et al., Initial Reports of the Deep Sea Drilling Project, Volume 11: Washington (U.S. Government Printing Office), p. 475482.

1973a. Low-latitude coccolith biostratigraphic zonation. In Edgar, N.T., Saunders, J.B., et al., Initial Reports of the Deep Sea Drilling Project, Volume 15: Washington (U.S. Government Printing Office), p. 685703.

1973b. Coccolith stratigraphy, Leg 10, Deep Sea Drilling Project. In Worzel, J.L., Bryant, W., et al., Initial Reports of the Deep Sea Drilling Project, Volume 10: Washington (U.S. Government Printing Office), p. $385-$ 406.

,1973c. Coccolith and silicoflagellate stratigraphy, Deep Sea Drilling Project Leg 18, eastern North Pacific. In Kulm, L.D., von Huene, R., et al., Initial Reports of the Deep Sea Drilling Project, Volume 18: Washington (U.S. Government Printing Office), p. 817-831.

1973d. Coccoliths and silicoflagellates from Deep Sea Drilling Project Leg 19, North Pacific Ocean and Bering Sea. In Creager, J.S., Scholl, D.W., et al., Initial Reports of the Deep Sea Drilling Project, Volume 19: Washington (U.S. Government Printing Office), p. 857867.

,1973e. Coccolith and silicoflagellate stratigraphy, Tasman Sea and southwestern Pacific Ocean, Deep Sea Drilling Project Leg 21. In Burns, R.E., Andrews, J.E., et al., Initial Reports of the Deep Sea Drilling Project, Volume 21: Washington (U.S. Government Printing Office), p. $885-893$.

,1975a. Coccolith and silicoflagellate stratigraphy, northwestern Pacific Ocean, Deep Sea Drilling Project Leg 32. In Larson, R.L., Moberly, R., et al., Initial Reports of the Deep Sea Drilling Project, Volume 32: Washington (U.S. Government Printing Office), p. 677-701.

,1975b. Silicoflagellate and coccolith stratigraphy, Deep Sea Drilling Project Leg 29. In Kennett, J.P., Houtz, R.E., et al., Initial Reports of the Deep Sea Drilling Project, Volume 29: Washington (U.S. Government Printing Office), p. 845-872.

1975c. Coccolith and silicoflagellate stratigraphy near Antarctica, Deep Sea Drilling Project Leg 28. In Hayes, D., Frakes, L.A., et al., Initial Reports of the Deep Sea Drilling Project, Volume 28: Washington (U.S. Government Printing Office), p. 709-723.

,1976a. Cenozoic silicoflagellate and coccolith stratigraphy, South Atlantic Ocean, Deep Sea Drilling Project Leg 36. In Hollister, C.D., Craddock, C., et al., Initial Reports of the Deep Sea Drilling Project, Volume 35: Washington (U.S. Government Printing Office), p. 885917.

,1976b. Silicoflagellate and coccolith stratigraphy, Norwegian-Greenland Sea, Deep Sea Drilling Project Leg 38. In Talwani, M., Udintsev, G., et al., Initial Reports of the Deep Sea Drilling Project, Volume 38: Washington (U.S. Government Printing Office), p. 843-856.

,1976c. Silicoflagellate and coccolith stratigraphy, southeastern Pacific Ocean, Deep Sea Drilling Project Leg 34. In Hart, S.R., Yeats, R.S., et al., Initial Reports of the Deep Sea Drilling Project, Volume 34: Washington (U.S. Government Printing Office), p. 715-735.

,1976d. Comments on some coccoliths and silicoflagellates from Deep Sea Drilling Project Leg 35. In Hollister, C.D., Craddock, C., et al., Initial Reports of the Deep Sea Drilling Project, Volume 35: Washington (U.S. Government Printing Office), p. 693-699. 
1977a. Coccolith and silicoflagellate stratigraphy, South Atlantic Ocean, Deep Sea Drilling Project Leg 39. In Perch-Nielsen, K., Supko, P.R., et al., Initial Reports of the Deep Sea Drilling Project, Volume 39: Washington (U.S. Government Printing Office), p. 825-839.

1977b. Cenozoic coccolith and silicoflagellate stratigraphy, offshore northwest Africa, Deep Sea Drilling Project Leg 41. In Lancelot, Y., Seibold, E., et al., Initial Reports of the Deep Sea Drilling Project, Volume 41: Washington (U.S. Government Printing Office), p. 689707.

in press. Cenozoic silicoflagellate and coccolith stratigraphy, northwestern Atlantic Ocean, Deep Sea Drilling Project Leg 43. In Tucholke, B., Vogt, P., et al., Initial Reports of the Deep Sea Drilling Project, Volume 43: Washington (U.S. Government Printing Office).

Bukry, D. and Foster, J.H., 1973. Silicoflagellate and diatom stratigraphy, Leg 16, Deep Sea Drilling Project. In van Andel, T.H., Heath, G.R., et al., Initial Reports of the Deep Sea Drilling Project, Volume 16: Washington (U.S. Government Printing Office), p. 815-871.

1974. Silicoflagellate zonation of Upper Cretaceous to lower Miocene deep-sea sediment: U.S. Geol. Surv. J. Res., v. 2, p. 303-310.

Carnevale, P., 1908. Radiolarie e Silicoflagellati di Bergonzano (Reggio Emilia): Mem. R. Ist. Veneto Sci., Let. ed. Arti, Venezia, v. 28, p. 1-39.

Ciesielski, P.F., 1975. Biostratigraphy and paleoecology of Neogene and Oligocene silicoflagellates from cores recovered during Antarctic Leg 28, Deep Sea Drilling Project. In Hayes, D., Frakes, L.A., et al., Initial Reports of the Deep Sea Drilling Project, Volume 28: Washington (U.S. Government Printing Office), p. 625-691.

Deflandre, G., 1932. Sur la systematique des Silicoflagellés: Soc. Bot. France Bull., v. 79, p. 494-506.

1938. Sur deux microfossiles siliceux énigmatiques (Silicoflagellidées?): Soc. Franç., Microsc. Bull., v. 7, p. 90-96.

1947. Phyllodictyocha nov. gen., Silicoflagellidés et formes affines du Miocène de Hongrie: Soc. Bot. France Bull., v. 93, p. 335-337.

1950. Contribution a l'étude des silicoflagellidés actuels et fossiles: Microscopie, v. 2, p. 72-108, 117-142, and 191-210.

Dumitrica, P., 1973a. Cretaceous and Quaternary radiolaria in deep sea sediments from the northwest [sic] Atlantic Ocean and Mediterranean Sea. In Ryan, W.B.F., Hsü, K.J., et al., Initial Reports of the Deep Sea Drilling Project, Volume 13: Washington (U.S. Government Printing Office), p. 829-901.

1973b. Miocene and Quaternary silicoflagellates in sediments from the Mediterranean Sea. In Ryan, W.B.F., Hsu, K.J., et al., Initial Reports of the Deep Sea Drilling Project, Volume 13: Washington (U.S. Government Printing Office), p. 902-923.

1973c. Paleocene, late Oligocene and postOligocene silicoflagellates in southwestern Pacific sediments cored on Deep Sea Drilling Project Leg 21. In Burns, R.E., Andrews, J.E., et al., Initial Reports of the Deep Sea Drilling Project, Volume 21: Washington (U.S. Government Printing Office), p. 837-883.

Ehrenberg, C.G., 1839. Über die Bildung der Kreidefelsen und des Kreidemergels durch unsichtbare Organismen: $K$. Preuss. Akad. Wiss. Berlin Ber., Jahrg. 1838, p. 59-148.

1840. 274 Blätter von ihm selbst ausgefuhrter Zeichnungen von ebenso vielen Arten: $K$. Preuss. Akad. Wiss. Berlin Ber., Jahrg. 1840, p. 197-219.

1844. Mittheilung über zwei neue Lager von Gebirgsmassen aus. Infusorien als Meeres-Absatz
Nord-Amerika und eine Vergleichung derselben mit den organischen Kreide-Gebilden in Europa und Afrika: $K$. Preuss. Akad. Wiss. Berlin Ber., Jahrg. 1844, p. 57-97.

1845. Neue Untersuchungen uber das kleinste Leben als geologisches Moment: K. Preuss Akad. Wiss. Berlin Ber., Jahrg. 1845, p. 53-87. 374. 1845. Mikrogeologie: Leipzig (Leopold Voss), p. 1-

Frenguelli, J., 1940. Consideraciones sobre los sílicoflagelados fósiles: Mus. La Plata Rev., Paleontol., v. 2 , p. $37-112$.

1951. Silicoflagelados del Trípoli de Mejillones (Chile): Physis [Buenos Aires], v. 20, p. 272-284.

Glezer, Z.I., 1960. Paleogenovye kremnevye zhgutikovye vodorosli (Silicoflagellatae) Zapadnoy Sibiri [Paleogene silicoflagellates of western Siberia]: Vses. Nauchno-Issled. Geol. Inst. Inform. Sbornik, Strat. i Paleont., no. 35, p. 127-136.

1964. Novye kremnevye zhgutikovye vodorosli Paleogena SSSR [New silicoflagellates from the Paleogene of the USSR]: Akad. Nauk SSSR, Novosti sistematiki nizshikh rasteniy, otdel. ottisk, p. 46-58.

1966. Silicoflagellatophyceae, in Gollerbakh, M.M. (Ed.), Cryptogamic plants of the U.S.S.R.: Akad. Nauk SSSR, V.A. Komarova Bot. Inst. (Translated from Russian by Israel Program for Scientific Translations Ltd., Jerusalem, 1970), v. 7, p. 1-363.

Gemeinhardt, K., 1930. Silicoflagellatae, in Rabenhorst, L. (Ed.), Kryptogamen-Flora von Deutschland, Osterreich und der Schweiz: Leipzig (Akad. Verlagsgessell.), v. 10, p. 187.

Haeckel, E.H.P.A., 1887. Cannorrhaphida: Challenger Rept., v. 18 , p. $1546-1569$.

Hajós, M., 1976. Stratigraphically important marine diatoms in the Sarmatian Paratethys sediments: Abstracts for the 4th Symposium on Fossil and Recent Diatoms, Oslo, August 30-September 3, 1976.

Hanna, G.D., 1930. A new genus of Silicoflagellata from the Miocene of Lower California: J. Paleontol., v. 4, p. 415416.

Hyman, L.H., 1940. The Invertebrates: Protozoa through Ctenophora: New York (McGraw-Hill Book Co., Inc.), p. 726 .

Ichikawa, W., Shimizu, I., and Bachmann, A., 1967. Fossil silicoflagellates and their associated uncertain forms in Iida Diatomite, Noto Peninsula, Central Japan: Kanazawa Univ. Sci. Rept., v. 12, p. 143-172.

Jerković, L., 1965. Sur quelques silicoflagellidés de Yougoslavie: Lab. Micropaleontol. Inst. Paleont. Mus. Paris, p. 1-8.

Jerkovic, L., 1969. Les nouvelles recherches de la superficie du squelette des silicoflagellidés: Univ. Sarajevu Biol. Inst. Godisnjaka, v. 22, p. 129-176.

Lemmermann, E., 1901. Silicoflagellatae: Deutsche. Bot. Gesell. Ber., v. 19, p. 247-271.

Ling, H.Y., 1970. Silicoflagellates from central North Pacific core sediments: Am. Paleontol. Bull., v. 58, p. 85-129.

1971. Silicoflagellates and ebridians from the Shinzan Diatomaceous Mudstone Member of the Onnagawa Formation (Miocene), northeast Japan: Second Plankt. Conf. Proc., p. 689-703.

1972. Upper Cretaceous and Cenozoic silicoflagellates and ebridians: Am. Paleontol. Bull., v. 62, p. $135-229$.

1973. Silicoflagellates and ebridians from Leg 19. In Creager, J.S., Scholl, D.W., et al., Initial Reports of the Deep Sea Drilling Project, Volume 19: Washington (U.S. Government Printing Office), p. 751-775. 
1975. Silicoflagellates and ebridians from Leg 31. In Ingle, J.C., Karig, D.E., et al., Initial Reports of the Deep Sea Drilling Project, Volume 31: Washington (U.S. Government Printing Office), p. 763-777.

Locker, S., 1974. Revision der Silicoflagellaten aus der Mikrogeologischen Sammlung von C.G. Ehrenberg: Eclog. Geol. Helv., v. 67, p. 631-646.

Loeblich, A.R., 3d, Loeblich, L.A., Tappan, H., and Loeblich, A.R., Jr., 1968. Annotated index of fossil and recent silicoflagellates and ebridians with descriptions and illustrations of validly proposed taxa: Geol. Soc. Am. Mem. 106, 319 p.

Mann, A., 1907. Report on the diatoms of the voyages of the Albatross in the Pacific Ocean, 1888-1904: Contrib. U.S. Nat. Herb. Smithsonian Inst., v. 10, p. 221-442.

Martini, E., 1971. Neogene silicoflagellates from the equatorial Pacific. In Winterer, E.L., Riedel, W.R., et al., Initial Reports of the Deep Sea Drilling Project, Volume 7: Washington (U.S. Government Printing Office), p. 16951708.

1972. Silicoflagellate zones in the late Oligocene and early Miocene of Europe: Senckenberg Lethaea, v. 53, p. $119-122$.

1974. Silicoflagellate zones in the Eocene and early Oligocene: Senckenberg. Lethaea, v. 54, p. 527-532.

Minchin, E.A., 1900. Sponges. In Lankester, E.R. (Ed.), A treatise on zoology: London (Adam and Charles Black), chap. 3, p. 1-178.

Perch-Nielsen, K., 1969. Die Coccolithen einiger Danischer Maastrichtien- und Danienlokalitäten: Geol. Soc. Denmark Bull., v. 19, p. 51-69.
1975. Late Cretaceous to Pleistocene silicoflagellates from the southern southwest Pacific, Deep Sea Drilling Project Leg 29. In Kennett, J.P., Houtz, R.E., et al., Initial Reports of the Deep Sea Drilling Project, Volume 29: Washington (U.S. Government Printing Office), p. 721.

Ridley, S.O., 1887. Report on the Monaxonida collected by H.M.S. Challenger during the years 1873-1876: Challenger Rept., v. 20, p. i-liii, 1-265.

Schulz, P., 1928. Beiträge zue Kenntnis fossiler und rezenter Silicoflagellaten: Bot. Archiv., v. 21, p. 225-292.

Schulze, F.E., 1887. Report on the Hexactinellida collected by H.M.S. Challenger during the years 1872-1876: Challenger Rept., v. 21, p. 1-513.

Sollas, I.B.J., 1906. Porifera (Sponges). In Harmer, S.F. and Shipley, A.E. (Eds.), The Cambridge natural history, v. 1, Reprint edition, 1959: New York (Hafner Publishing Co.), p. $165-242$.

Sollas, W.J., 1888. Report on the Tetractinellida collected by H.M.S. Challenger during the years 1873-1876: Challenger Rept., v. 21, p. i-clxvi, 1-458.

Stradner, H., 1961. Über fossile Silicoflagelliden und die Möglichkeit ihrer Verwendung in der Erdolstratigraphie: Erdöl Kohle, v. 14, p. 87-92.

Uchio, T., 1974. Tertiary nannoplankton stratigraphy of Sado Island, Niigata Prefecture, and a proposal of the Braarudosphaera bigelowi-Coccolithus pelagicus Zone for the Pliocene of Japanese oil fields of Japan Sea side: Japan Geol. Surv. Rept., no. 250-1, p. 235-254. 



\section{PLATE 1}

Silicoflagellates From DSDP Legs 36 and 44

Magnification $800 \times$; scale bar equals $10 \mu \mathrm{m}$.

Figure 1 Cannopilus depressus (Ehrenberg).

Sample 391A-7-1, 96-98 cm (327 m).

Figure 2 Corbisema bimucronata bimucronata Deflandre. Hastatoid, Sample 390A-7-4, 87-88 cm (70 m).

Figures 3-5 Corbisema hastata globulata Bukry.

3. Sample $390 \mathrm{~A}-7-2,88-90 \mathrm{~cm}(68 \mathrm{~m})$.

4, 5. Sample $390 \mathrm{~A}-7-4,87-88 \mathrm{~cm}(70 \mathrm{~m})$.

Figures 6, 7 Corbisema hastata hastata (Lemmermann).

6. Typical, Sample 327A-8-1, 130-132 cm (72 m).

7. Broad form resembling C. toxeuma, Sample $390 \mathrm{~A}-7-2,88-90 \mathrm{~cm}(68 \mathrm{~m})$.

Figures 8, 9 Corbisema hastata minor (Schulz).

8. Sample $390 \mathrm{~A}-7-4,87-88 \mathrm{~cm}(70 \mathrm{~m})$.

9. Sample $390 \mathrm{~A}-7-2,88-90 \mathrm{~cm}(68 \mathrm{~m})$.

Figures 10-12 Corbisema toxeuma n. sp.

10. USNM 243139, Sample 390A-7-2, $88-90 \mathrm{~cm}$ $(68 \mathrm{~m})$

11. Holotype, USNM 243138, Sample 390A-7-3, $79-81 \mathrm{~cm}(69 \mathrm{~m})$.

12. USNM 243140, Sample 390A-7-4, $87-88 \mathrm{~cm}$ (70 m).

Figures 13-17 Corbisema triacantha convexa n. subsp.

13. USNM 243142, Sample 390 A-7-3, $79-81 \mathrm{~cm}$ $(69 \mathrm{~m})$.

14, 15. USNM 243143, Sample 390A-7-2, 88-90 $\mathrm{cm}(68 \mathrm{~m})$, basal and apical focuses.

16, 17. Holotype, USNM 243141, Sample 390A$7-4,87-88 \mathrm{~cm}(70 \mathrm{~m})$, basal and apical focuses.

Figure 18 Corbisema triacantha (Enrenberg) s. ampl.

Sample 391A-13-5, 29-31 cm (532 m). 
PLATE 1

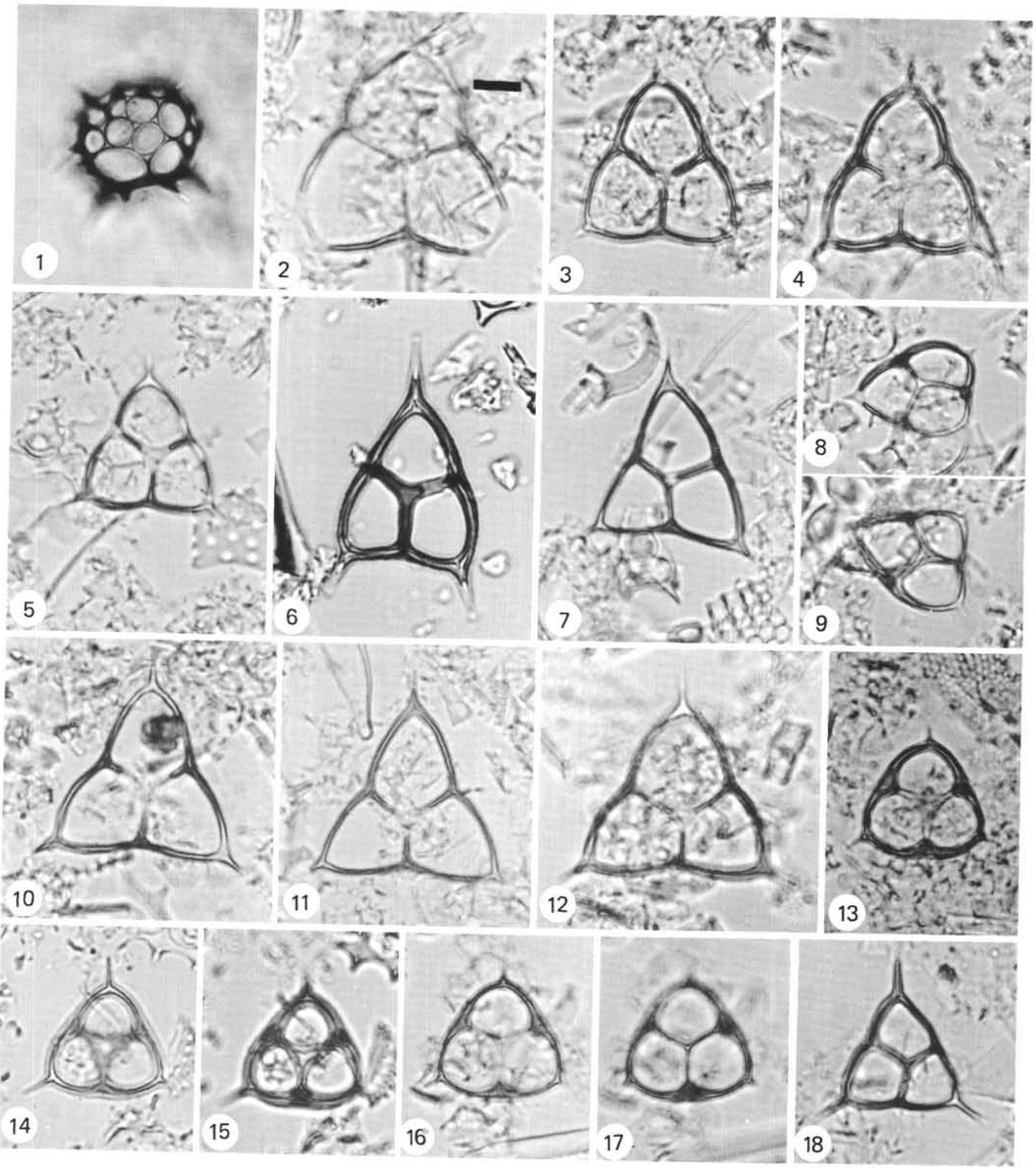


PLATE 2

Silicoflagellates From DSDP Legs 44 and 44A

Magnification $800 \times$; scale bar equals $10 \mu \mathrm{m}$.

Figures 1-4 Corbisema? xenica n. sp.

1, 2. Holotype, USNM 243144, Sample 390A-6-

$3,75-77 \mathrm{~cm}(61 \mathrm{~m})$, basal and apical focuses.

3 , 4. USNM 243145, Sample 390A-6-4, 75-77 cm $(62 \mathrm{~m})$, basal and apical focuses.

Figures 5-8 Dictyocha brevispina ausonia (Deflandre).

5. Sample 391A-13-1, 53-55 cm (526 m), aberrant form.

6, 8. Sample 391A-13-1, 53-55 cm (526 m).

7. Sample $391 \mathrm{~A}-13-5,29-31 \mathrm{~cm}(532 \mathrm{~m})$.

Figures 9, 10 Dictyocha brevispina brevispina (Lemmermann). Naviculopsoid variants.

9. Sample 394A-6-6, 74-76 cm (363 m).

10. Sample 391A-7-3, 86-88 cm (329 m).

Figure 11 Dictyocha fibula fibula Ehrenberg.

Sample 394A-6-6, 74-76 cm (363 m).

Figures 12-16 Dictyocha pulchella Bukry.

12. Sample $391 \mathrm{~A}-13-5,29-31 \mathrm{~cm}(532 \mathrm{~m})$.

13, 15. Sample 394A-6-6, 75-76 cm (363 m).

14. Sample 391A-10-5, 116-118 cm (381 m).

16. Slightly deflandroid, Sample $391 \mathrm{~A}-12-5,115$ $117 \mathrm{~cm}(476 \mathrm{~m})$. 
PLATE 2

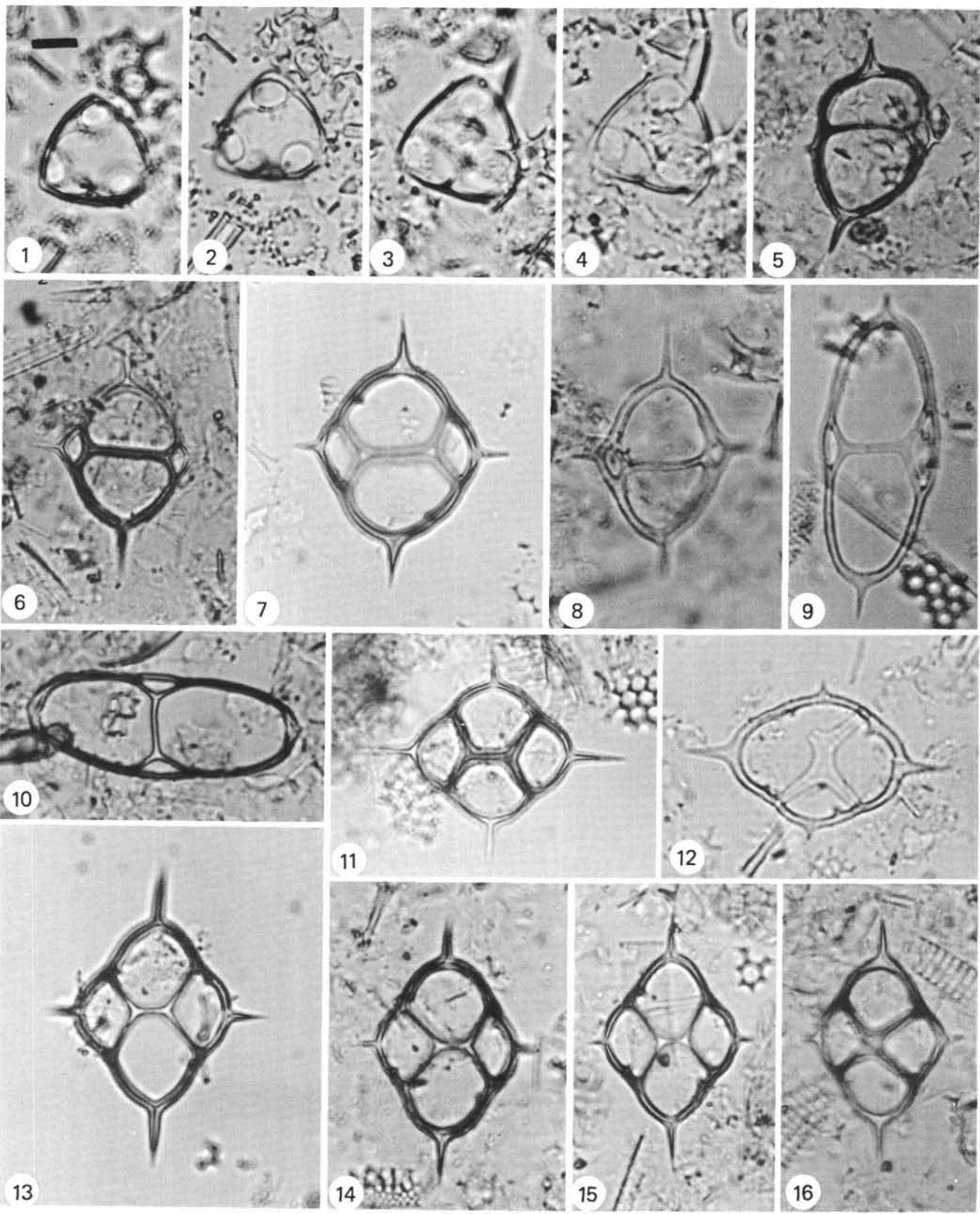




\section{PLATE 3}

Silicoflagellates From DSDP Legs 36 and 44

Figures 1, 2 magnified 350X; scale bar equals $20 \mu \mathrm{m}$.

Figure 3 magnified $450 \times$; scale bar equals $20 \mu \mathrm{m}$.

Figures 4-13 magnified $800 \times$; scale bar equals $10 \mu \mathrm{m}$.

Figures 1-3 Distephanus? acanthicus n. sp.

1, 2. Holotype, USNM 243146, Sample 390A-7$4,87-88 \mathrm{~cm}(70 \mathrm{~m})$, basal and apical focuses. See also Figure 5 in text.

3. USNM 243147, Sample $390 \mathrm{~A}-7-4,87-88 \mathrm{~cm}$ $(70 \mathrm{~m})$, fragment.

Figures 4, 5 Distephanus crux crux (Ehrenberg).

Sample 391A-13-5, 29-31 cm (532 m).

4. Normal.

5. Triangular variant.

Figures 6-11 Distephanus crux crux (Ehrenberg)? (elliptica-like).

6, 9. Sample 391A-13-1, 53-55 cm (526 m), basal and apical focuses.

7, 8. Sample 391A-13-5, 29-31 cm (532 m), basal and apical focuses.

10, 11. Sample 391A-13-5, 29-31 cm (532 m), basal and apical focuses.

Figures 12, 13 Distephanus crux loeblichii n. subsp.

12, 13. Holotype, USNM 243148, Sample 328B-4$3,60-62 \mathrm{~cm}(40 \mathrm{~m})$, basal and apical focuses. 
PLATE 3
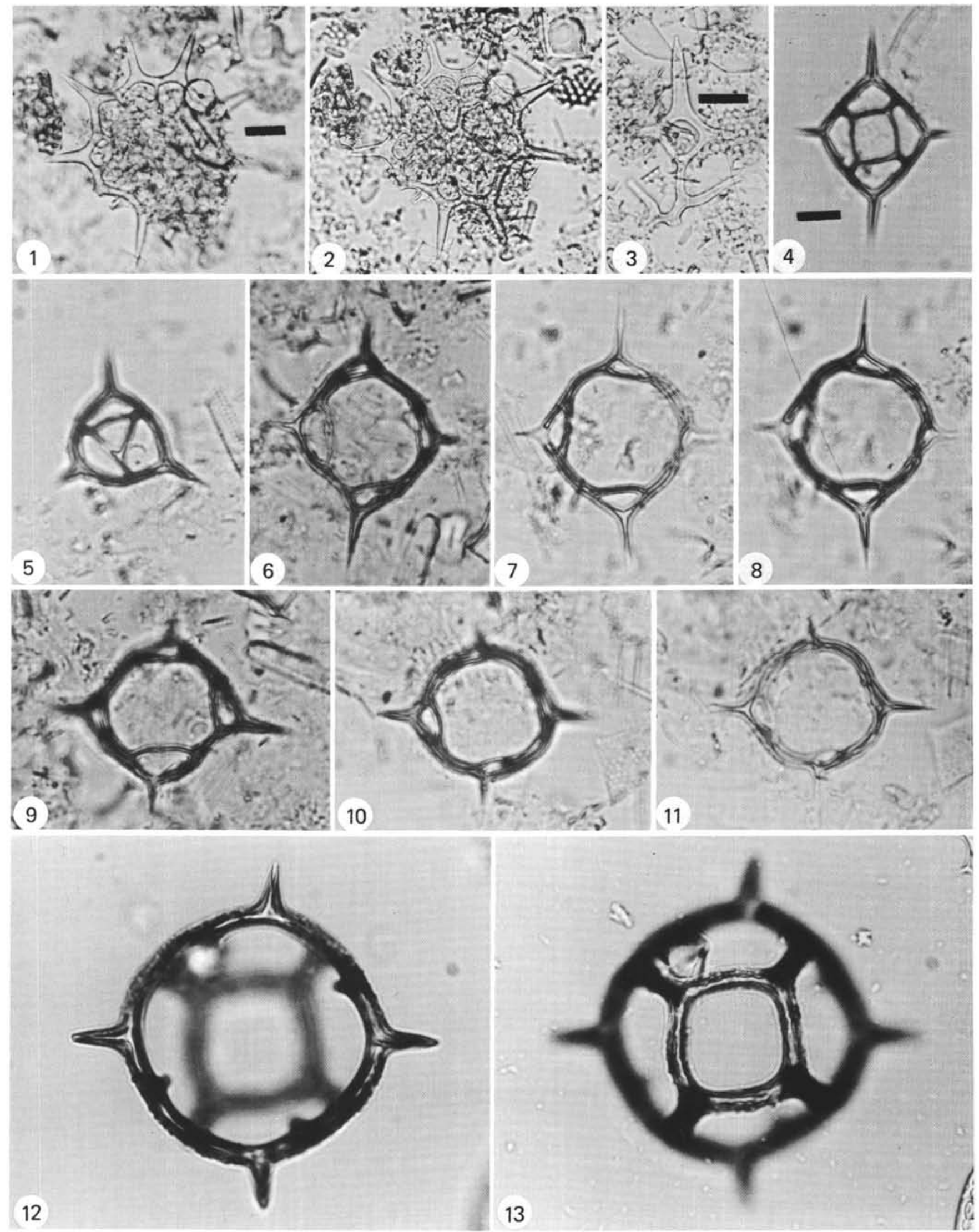

13
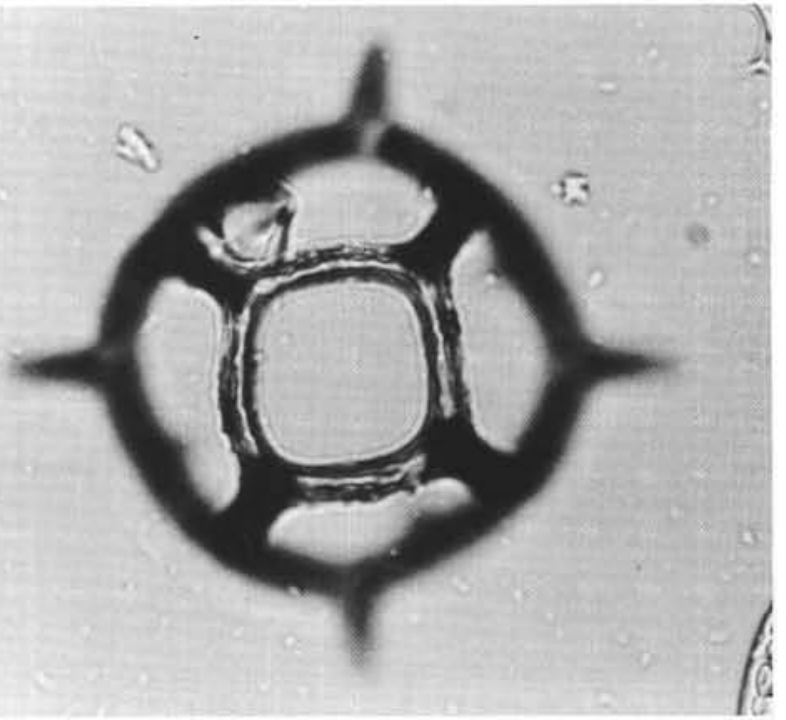


\section{PLATE 4 \\ Silicoflagellates From DSDP Legs 29, 36, and 44 Magnification $800 \times$; scale bar equals $10 \mu \mathrm{m}$.}

Figures 1-6 Distephanus crux loeblichii n. subsp.

1, 2. USNM 243149, Sample 328B-4-3, $60-62 \mathrm{~cm}$ $(40 \mathrm{~m})$, apical and basal focuses.

3, 4. USNM 243150, Sample 280A-6-1, $130 \mathrm{~cm}$ $(102 \mathrm{~m})$, basal and apical focuses.

5, 6. USNM 243151, Sample 328B-4-3, 60-62 cm $(40 \mathrm{~m})$, apical and basal focuses.

Figures 7, 8 Distephanus longispinus (Schulz).

Sample 391A-7-1, 96-98 cm (327 m).

Figures 9, 10 Distephanus schauinslandii Lemmermann.

Sample 391A-13-1, 53-55 cm (526 m). 


\section{PLATE 4}

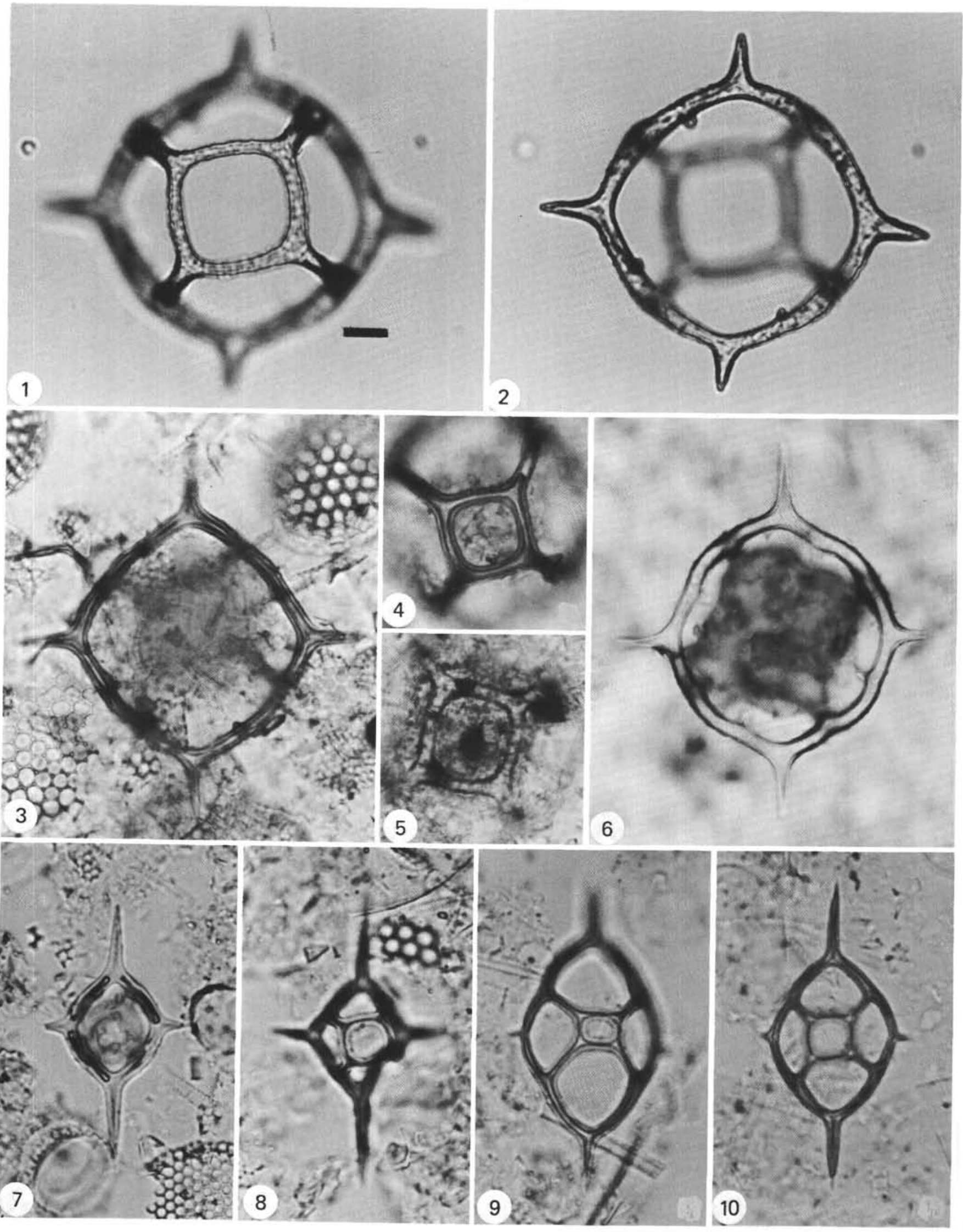




\section{PLATE 5}

Silicoflagellates From DSDP Legs 19 and 44, and USGS Cores GSCD 466 and OCS-CAL 75-70, No. 1

Figures 1-7, 11, 13-15 magnified $800 \times$; scale bar equals $10 \mu \mathrm{m}$. Figures 8-10, 12 magnified 450X; scale bar equals $20 \mu \mathrm{m}$.

Figure 1 Distephanus stradneri (Jerković). Sample 391A-13-1, 53-55 cm (526 m).

Figures 2, $3 \quad$ Distephanus trioctus $\mathrm{n}$. sp.

Holotype, USNM 243152, Sample OCS-CAL 7570 , No. 1, 749-840, apical and basal focuses.

Figure 4 Distephanus? sp.

Sample 390A-6-4, 75-77 cm (62 m).

Figure $5 \quad$ Macrora barbadensis (Deflandre). Sample 390A-2-2, 75-77 cm (21 m).

Figures 6, 7 Mesocena apiculata curvata Bukry.

6. Sample 391A-13-5, 29-31 cm (532 m).

7. Sample $391 \mathrm{~A}-10-5,116-118 \mathrm{~cm}(381 \mathrm{~m})$.

Figure $8 \quad$ Mesocena connudata Bukry. Sample 390A-6-4, 75-77 cm (62 m).

Figures 9-13 Mesocena diodon diodon Ehrenberg.

9. Sample 394A-6-6, 74-76 cm (363 m).

10. Sample 391A-10-3, $56-58 \mathrm{~cm}(377 \mathrm{~m})$.

11, 13. Sample GSCD 466, CC $(0.1 \mathrm{~m})$.

12. Sample $391 \mathrm{~A}-7-1,96-98 \mathrm{~cm}$ (327 m).

Figures 14, 15 Mesocena diodon nodosa n. subsp. Holotype, USNM 243153, Sample 192-13-2, 69-70 $\mathrm{cm}(233 \mathrm{~m})$, high and low focuses. 

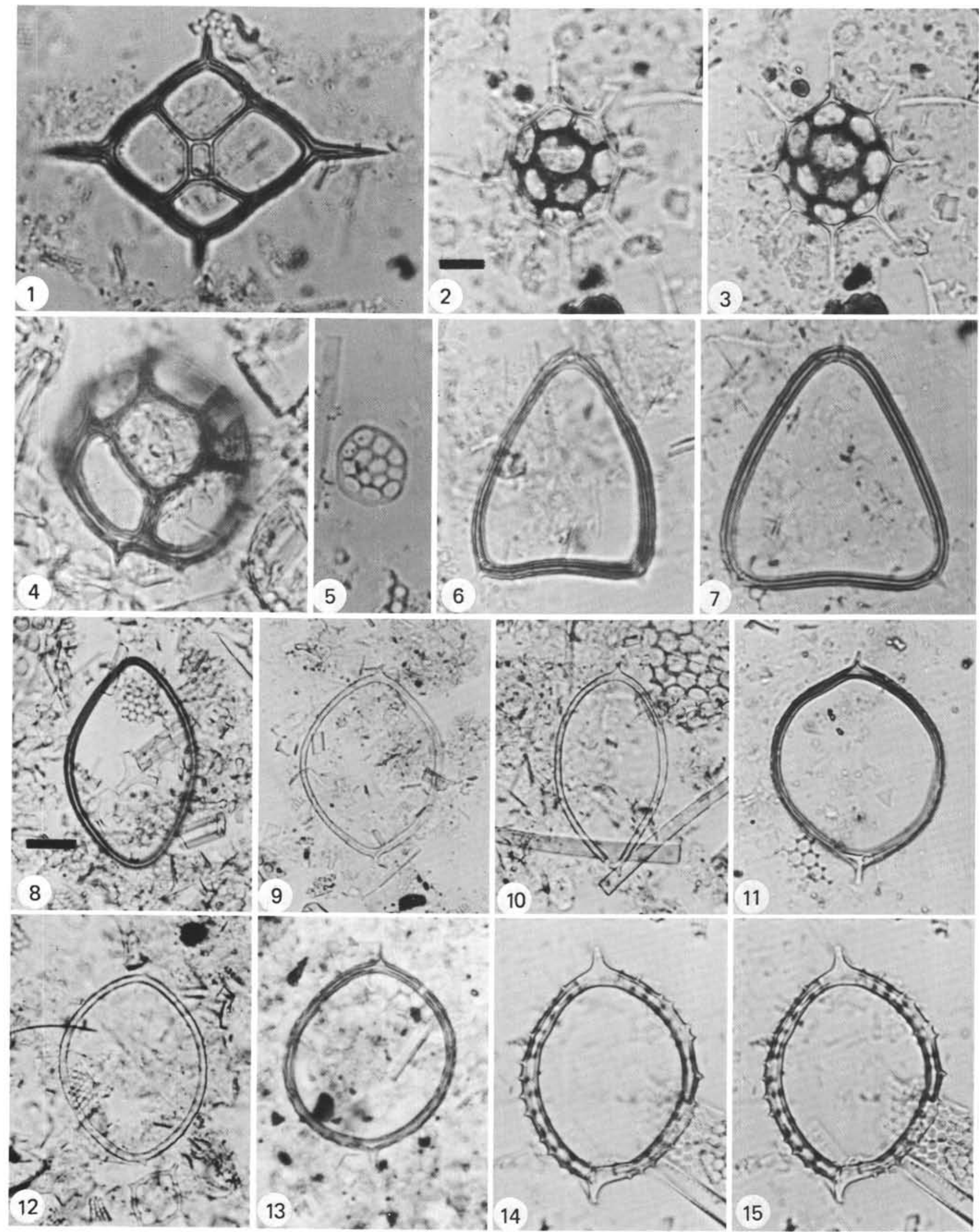


\section{PLATE 6}

Silicoflagellates From DSDP Legs 19, 36, and 44 and USGS

Cores GSCD 466 and LEE-2-76-SC-161

Magnification $800 \times$; scale bar equals $10 \mu \mathrm{m}$.

Figures 1-5 Mesocena diodon nodosa n. subsp.

1. USNM 243154, Sample 329-1-3, 50-51 cm (3 $\mathrm{m})$.

2. USNM 243155 , Sample 192-13-2, $69-70 \mathrm{~cm}$ $(233 \mathrm{~m})$.

3. USNM 243156, Sample 329-1-3, 50-51 cm (3 $\mathrm{m})$.

4. USNM 243157, Sample LEE-2-76-SC-161.

5. USNM 243158, Sample LEE-2-76-SC-161.

Figures 6-13 Mesocena elliptica (Ehrenberg).

6. 13. Sample $391 \mathrm{~A}-13-5,29-31 \mathrm{~cm}(532 \mathrm{~m})$.

7- 9, 12. Sample 391A-13-1, 53-55 cm (526 m).

10. Sample $391 \mathrm{~A}-10-3,56-58 \mathrm{~cm}(377 \mathrm{~m})$.

11. Sample GSCD 466, CC $(0.1 \mathrm{~m})$. 
PLATE 6
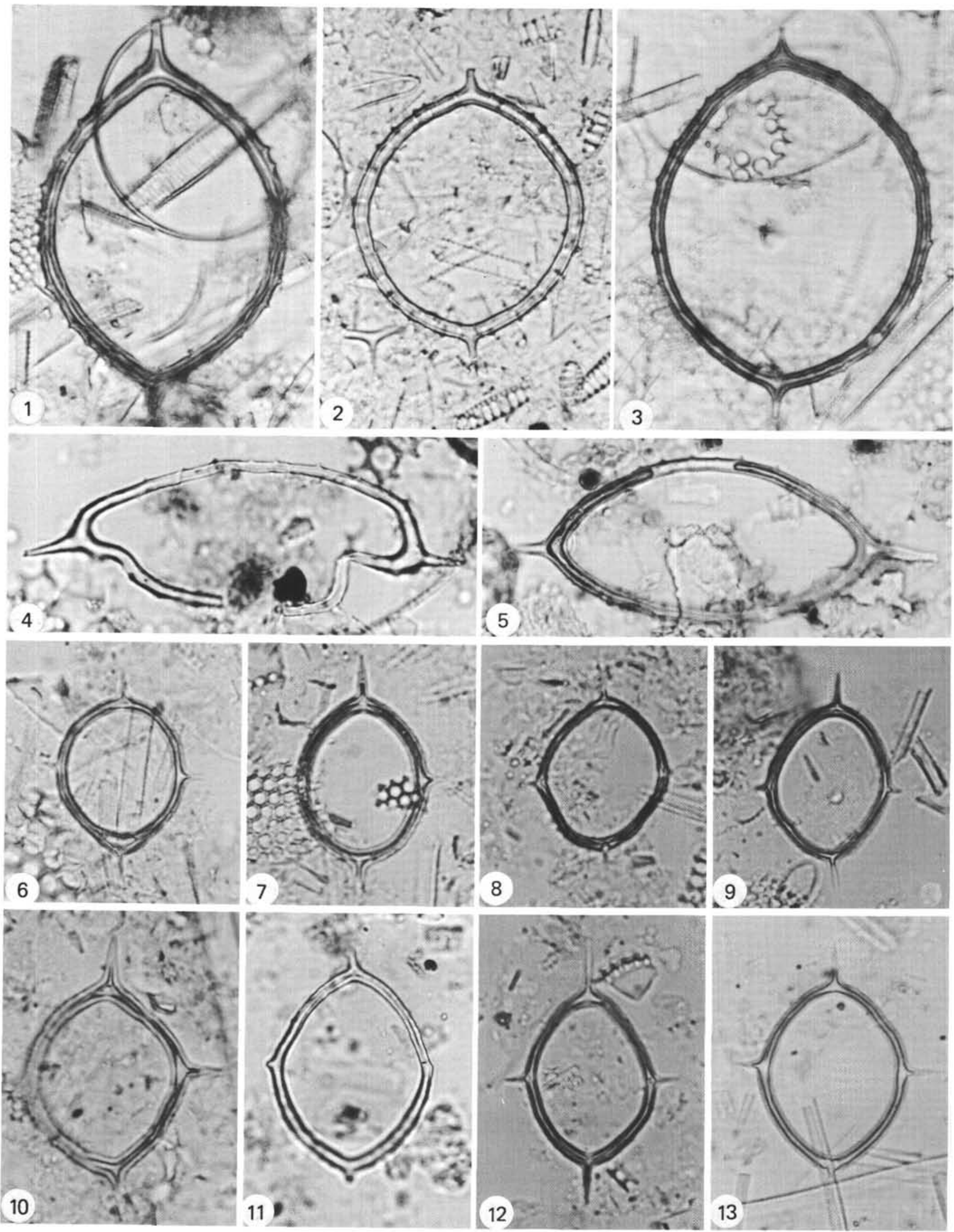


\section{PLATE 7}

\section{Silicoflagellates From DSDP Legs 43 and 44}

Figures 1, 2, 8, 9 magnified $800 \times$; scale bar equals $10 \mu \mathrm{m}$.

Figures 3-7, 11, 12 magnified $450 \times$; scale bar equals $20 \mu \mathrm{m}$.

Figure 10 magnified $550 \times$; scale bar equals $20 \mu \mathrm{m}$.

Figures 1-5 Mesocena quadrangula Ehrenberg ex Haeckel.

1, 4. Sample 394A-6-6, $74-76 \mathrm{~cm}(363 \mathrm{~m})$.

2, 3. Sample $391 \mathrm{~A}-10-3,56-58 \mathrm{~cm}(377 \mathrm{~m})$.

5. Sample $391 \mathrm{~A}-7-3,96-98 \mathrm{~cm}(327 \mathrm{~m})$.

Figure $6 \quad$ Mesocena ovata Bukry.

Sample 390A-6-4, 75-77 cm (62 m).

Figures 7, $8 \quad$ Mesocena venusta Bukry.

7. Sample $390 \mathrm{~A}-6-3,75-77 \mathrm{~cm}(61 \mathrm{~m})$.

8. Sample $386-14-5,134-135 \mathrm{~cm}(335 \mathrm{~m})$.

Figures 9, 10 Mesocena triodon Bukry.

Sample 391A-7-1, 96-98 cm (327 m).

Figure $11 \quad$ Naviculopsis eobiapiculata Bukry.

Sample 390A-6-3, 75-77 cm (61 m).

Figure 12 Naviculopsis foliacea foliacea Deflandre.

Sample 390A-6-4, 75-77 cm (62 m). 


\section{PLATE 7}
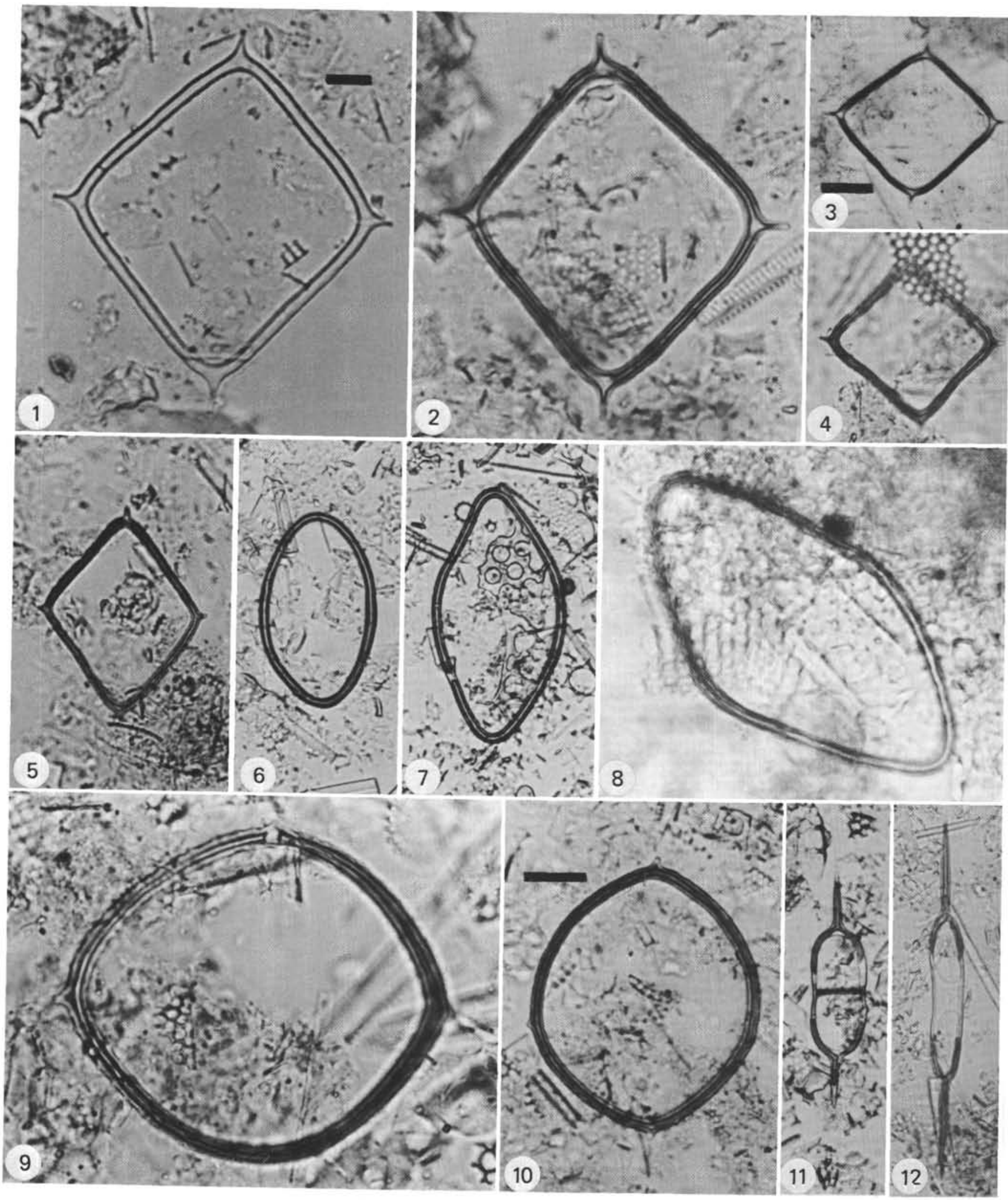

$\sin ^{2}+x^{1}$ 


\section{PLATE 8}

Silicoflagellates From DSDP Leg 44

Magnification $800 \times$; scale bar equals $10 \mu \mathrm{m}$.

Figures 1-8 Naviculopsis foliacea tumida $\mathrm{n}$. subsp.

1, 2. Holotype, USNM 243159, Sample 390A-6$3,75-77 \mathrm{~cm}(61 \mathrm{~m})$, basal and apical focuses.

3. USNM 243160, Sample 390A-6-3, $75-77 \mathrm{~cm}$ $(61 \mathrm{~m})$, oblique view.

4. USNM 243161, Sample 390A-6-3, 75-77 cm $(61 \mathrm{~m})$, side view.

5. USNM 243162, Sample 390A-6-3, 75-77 cm $(61 \mathrm{~m})$, oblique view.

6. USNM 243163, Sample 390A-6-4, 75-77 cm $(62 \mathrm{~m})$, oblique view.

7. USNM 243164, Sample 390A-6-4, 75-77 cm $(62 \mathrm{~m})$, oblique view.

8. USNM 243165 , Sample $390 \mathrm{~A}-6-4,75-77 \mathrm{~cm}$ $(62 \mathrm{~m})$, oblique view.

Figures 9, 10 Naviculopsis ponticula (Ehrenberg). Sample 391A-10-3, 56-58 cm (377 m).

Figure 11 Naviculopsis quadrata (Ehrenberg).

Sample 391A-7-1, 96-98 cm (327 m), fragment.

Figures 12-15 Naviculopsis robusta Deflandre.

12. Sample $390 \mathrm{~A}-7-2,88-90 \mathrm{~cm}(68 \mathrm{~m})$.

13- 15. Sample $390 \mathrm{~A}-7-4,87-88 \mathrm{~cm}(70 \mathrm{~m})$. 


\section{PLATE 8}

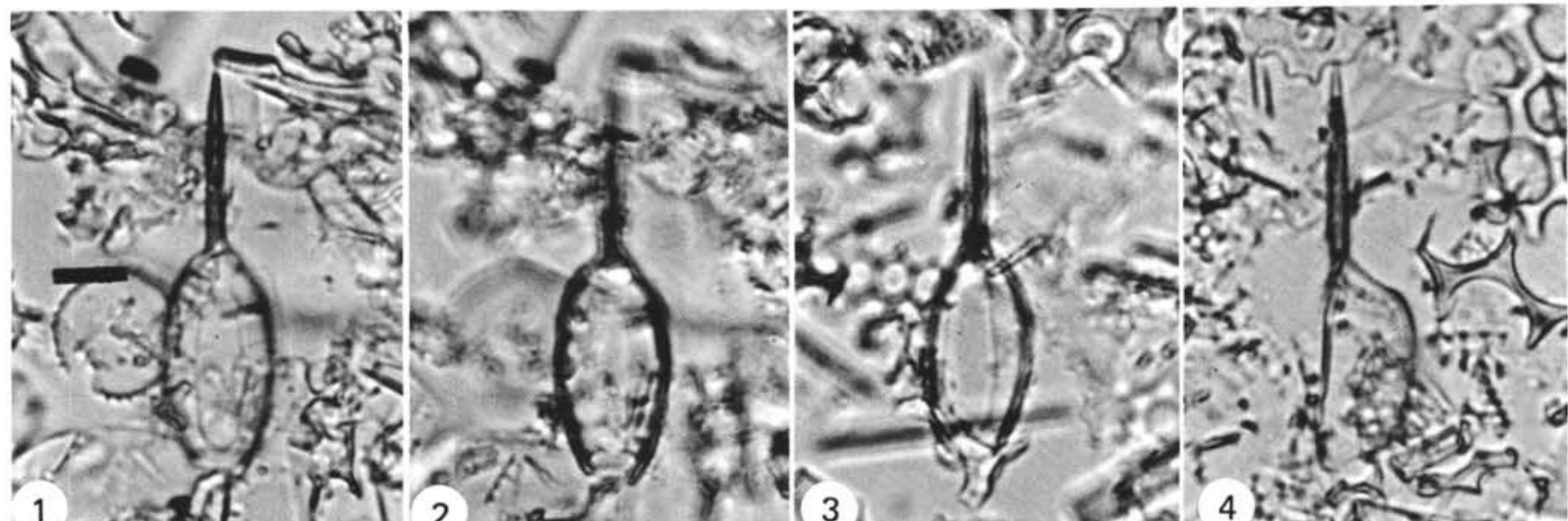
$1 \ldots$.

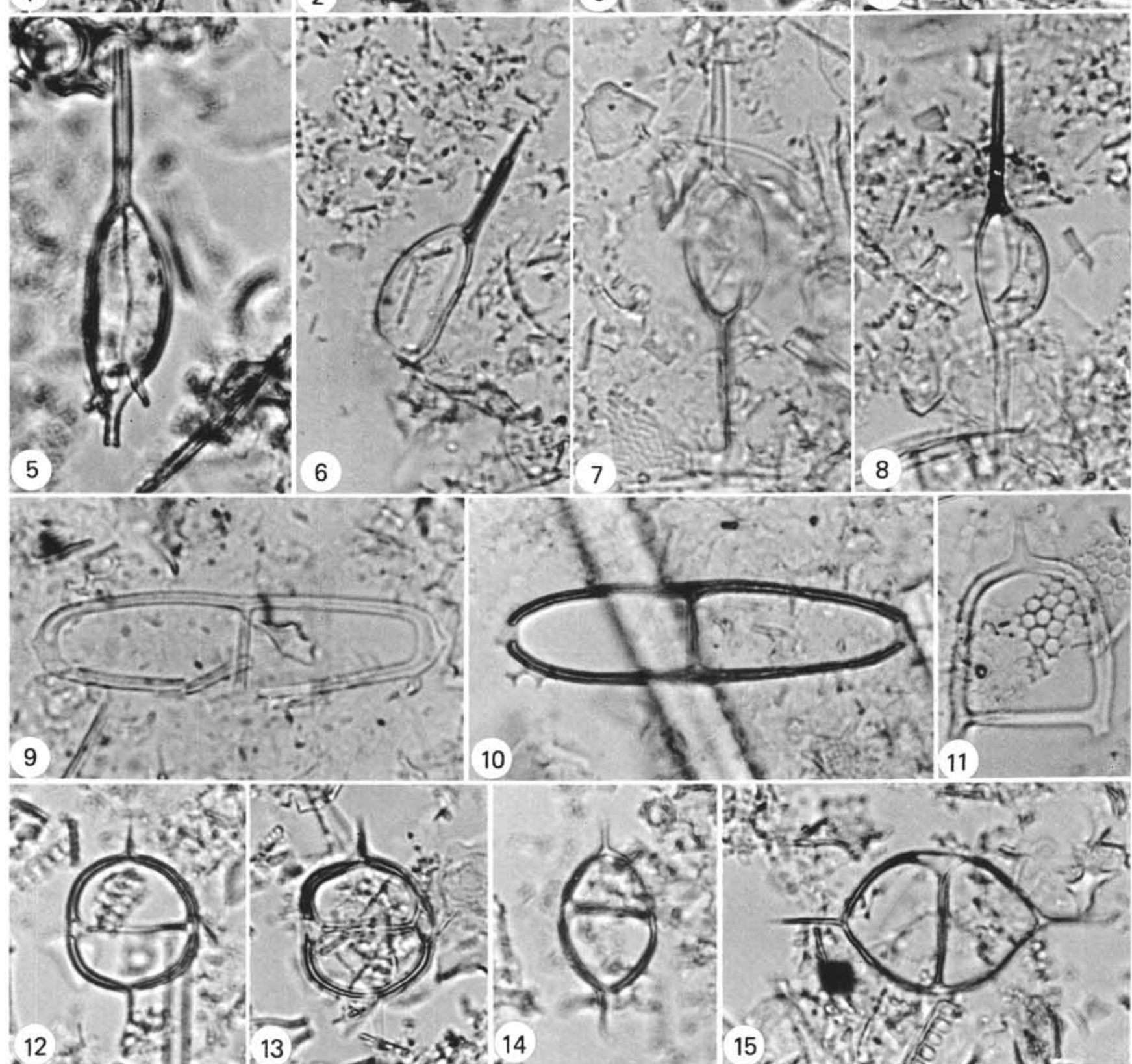




\section{PLATE 9}

Silicoflagellates, Diatoms and Coccoliths From DSDP Legs 41 and 44

Figures 1, 2, 4-9, 12 magnified $800 \times$; scale bar equals $10 \mu \mathrm{m}$.

Figure 3 magnified $450 \times$; scale bar equals $20 \mu \mathrm{m}$.

Figures 10, 11 magnified $1900 \times$; scale bar equals $5 \mu \mathrm{m}$.

Figures 1, 2 Naviculopsis lata (Deflandre).

1. Sample 391A-12-5, $115-117 \mathrm{~cm}(476 \mathrm{~m})$.

2. Sample 369A-18-3, 67-68 cm (207 m).

Figure 3 Rocella gelida (Mann).

Sample 391A-10-3, 56-68 cm (377 m).

Figures 4, 5 Coscinodiscus sp.

4. Sample $390 \mathrm{~A}-6-3,75-77 \mathrm{~cm}(61 \mathrm{~m})$.

5. Sample $390 \mathrm{~A}-6-4,75-77 \mathrm{~cm}(62 \mathrm{~m})$.

Figure 6 Actinocyclus sp. aff. A. lanceolatus (Castracane). Sample 391A-7-1, 96-98 cm (327 m).

Figure $7 \quad$ Euodia semicircularis (Brightwell). Sample 391A-7-1, 96-98 cm (327 m).

Figures 8, 9 Triceratium? sp.

Sample 391A-12-5, 115-117 cm (476 m), high and low focuses.

Figures 10, 11 Braarudosphaera sp.

Sample 390-1-6, 75-77 cm (7 m); unusual symmetric, beehive-shaped specimen, crosspolarized light and bright field.

Figure 12 Eocene coccoliths in smear-slide preparation of Sample 390-1-6, 75-77 cm (7 m), cross-polarized light. The four largest specimens are Braarudosphaera sp. (center), Micrantholithus procerus Bukry and Bramlette (lower left), Reticulofenestra umbilica (Levin) (lower center), and paddle-shaped Bramletteius serraculoides Gartner (lower right). 


\section{PLATE 9}

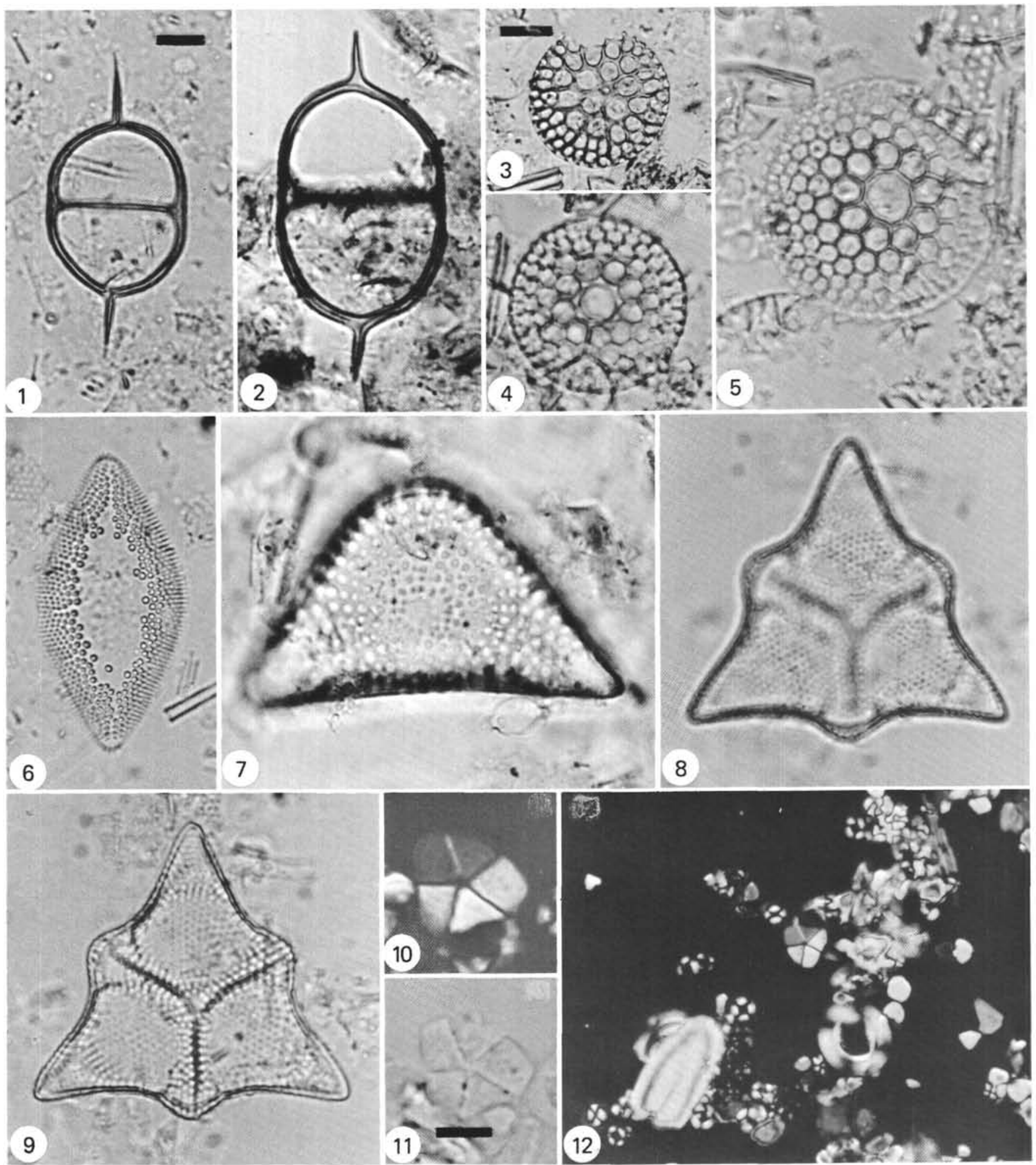


PLATE 10

Siliceous Sponge Spicules From DSDP Leg 44

Figures 1, 4, 7-10, 14, 15 magnified $350 \times$; scale bar equals $20 \mu \mathrm{m}$.

Figures 2, 3, 6, 11, 12, 16-19 magnified 450X; scale bar equals $20 \mu \mathrm{m}$.

Figures 5, 13 magnified $800 \times$; scale bar equals $10 \mu \mathrm{m}$.

Figures 1-7 Acanthostyles.

(1-3: Miocene; 4-7: Eocene)

1. Sample 391A-10-5, 116-118 cm (381 m).

2. Sample $391 \mathrm{~A}-13-1,53-55 \mathrm{~cm}(526 \mathrm{~m})$.

3. Sample 391A-12-5, 115-117 cm (476 m).

4, 6, 7. Sample 390A-4-5, 75-77 cm (45 m).

5. Sample $390 \mathrm{~A}-2-2,75-77 \mathrm{~cm}(21 \mathrm{~m})$.

Figures 8-10 Anatriaenes. (Miocene).

8. Sample 391A-10-5, 116-118 cm (381 m).

9. Sample 391A-13-5, 53-55 cm (526 m).

10. Sample 391A-12-5, 115-117 cm (476 m).

Figure 11 Anisochela. (Eocene)

Sample 390A-4-5, 75-77 cm (45 m).

Figures 12, 13 Calthrops. (Miocene)

12. Sample $391 \mathrm{~A}-12-5,115-117 \mathrm{~cm}(476 \mathrm{~m})$.

13. Sample $391 \mathrm{~A}-10-5,116-118 \mathrm{~cm}$ (381 m).

Figure 14 Centrotriaene. (Miocene).

Sample 391A-12-5, 115-117 cm (476 m).

Figure 15 Dichotriaene. (Miocene).

Sample 391A-12-5, 115-117 cm (476 m).

Figures 16-19 Discasters.

16. Sample 391A-10-5, 116-118 cm (381 m). Miocene.

17. Sample 391A-12-5, 115-117 cm (476 m). Miocene.

18, 19. Sample 390A-4-5, $75-77 \mathrm{~cm}$ (45 m). Eocene. 
PLATE 10
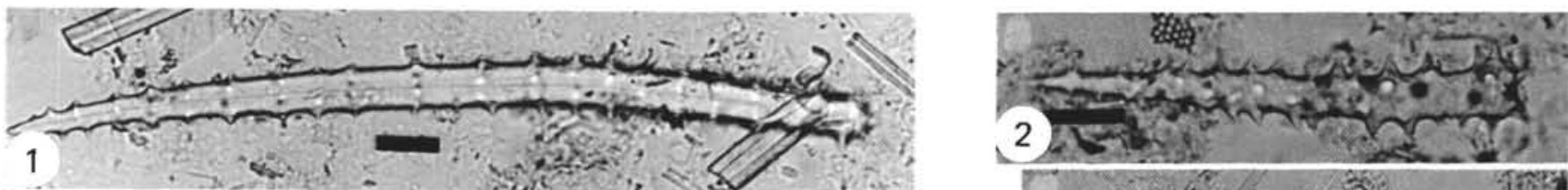

3 - 1 -

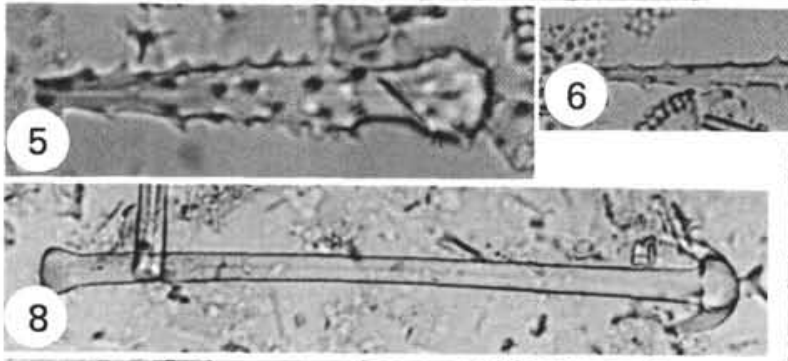

19:30
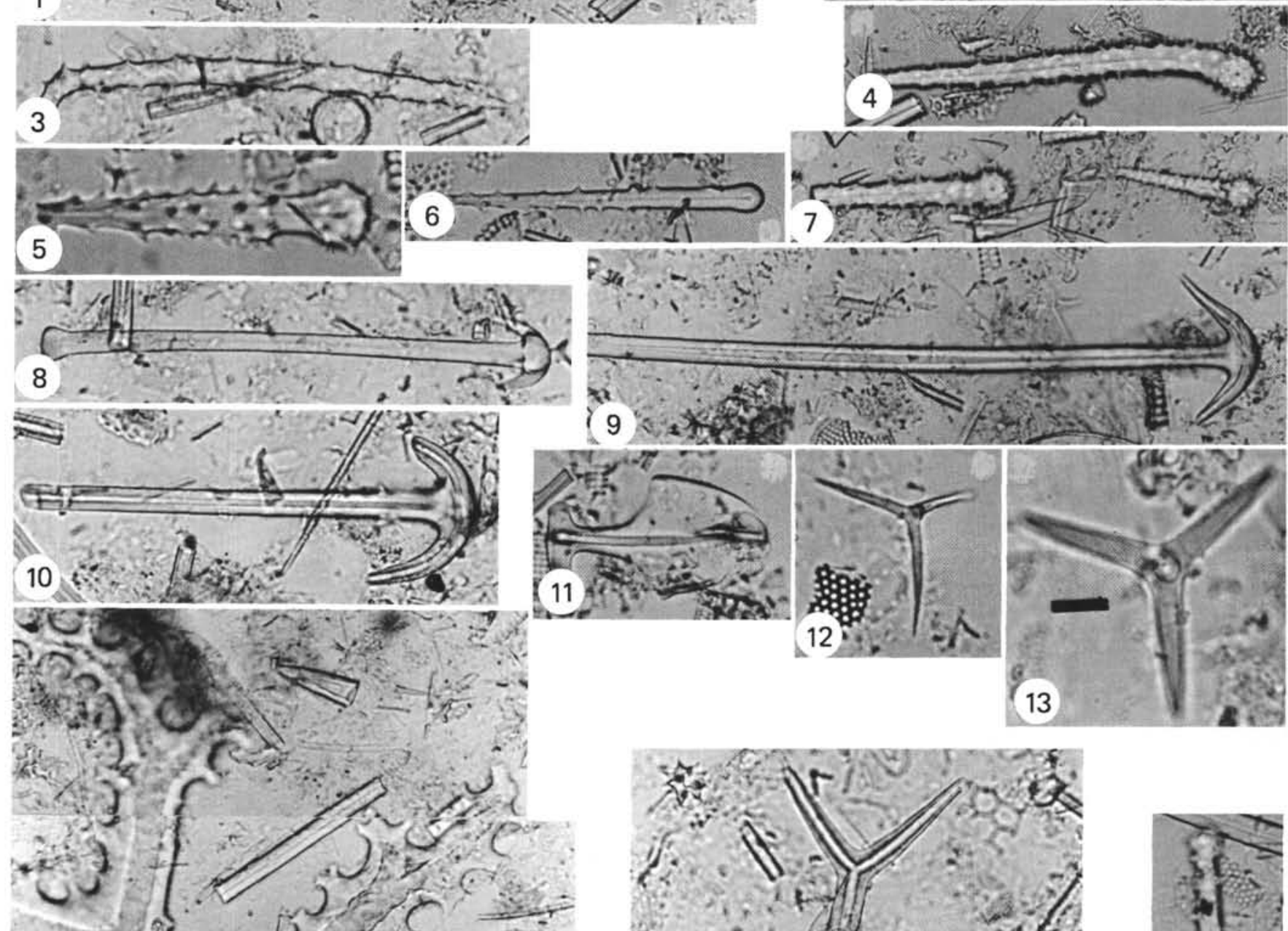

9 s s toses
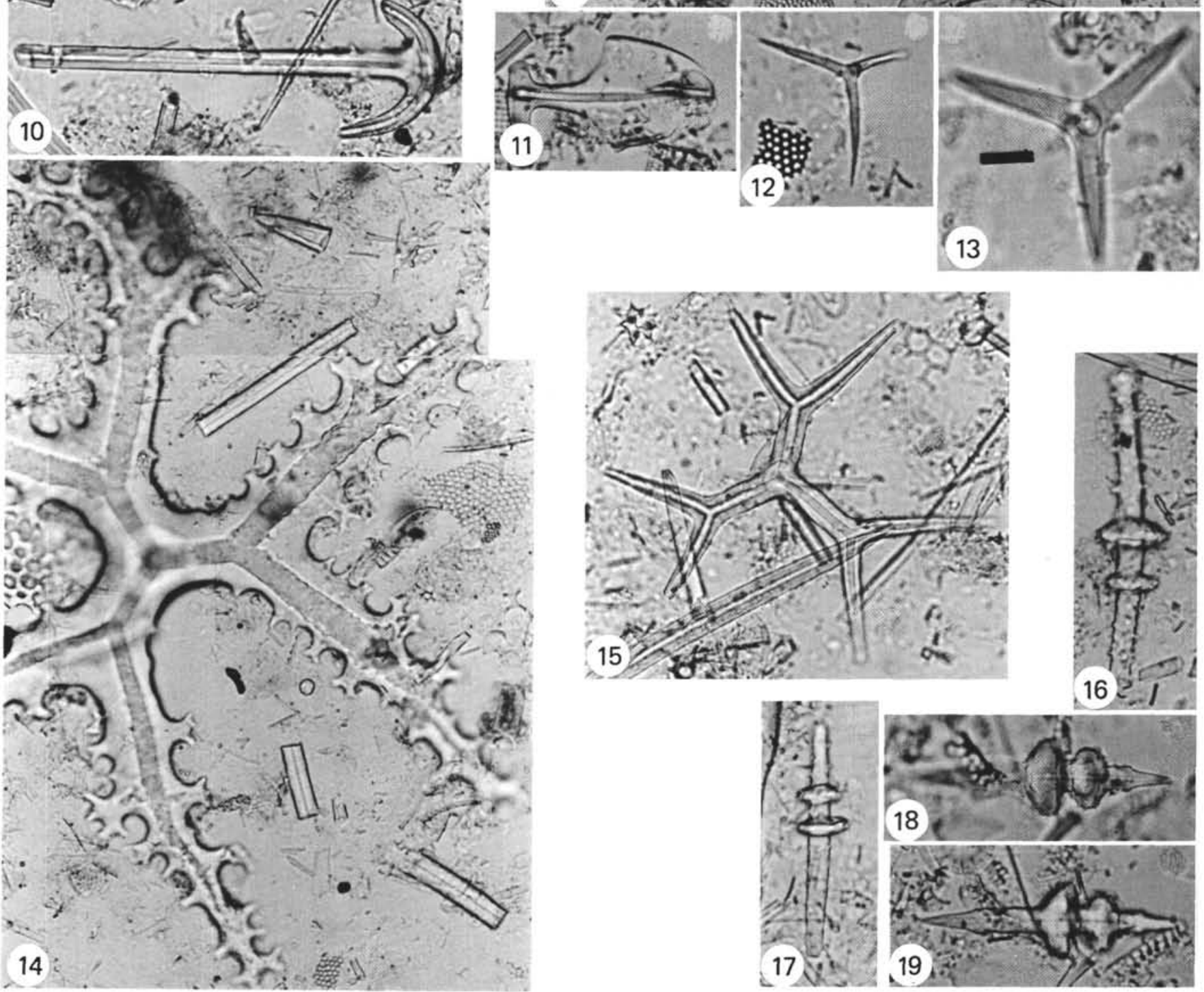


\section{PLATE 11}

Siliceous Sponge Spicules From DSDP Legs 1, 38, 43, and 44

Figures 1-3, 7, 19-24 magnified $800 \times$; scale bar equals $10 \mu \mathrm{m}$. Figures 4, 10-12, 16-18 magnified 450X; scale bar equals $20 \mu \mathrm{m}$. Figures 5, 6, 8, 9, 13-15 magnified 350X; scale bar equals $20 \mu \mathrm{m}$.

Figures 1-3 Isochela.

1. Sample 390A-2-2, 75-77 cm (21 m). Eocene.

2, 3. Sample 391A-10-5, 116-118 cm (381 m). Miocene.

Figure 4 Pleisioaster. (Miocene).

Sample 391A-12-5, 115-117 cm (476 m).

Figure $5 \quad$ Oxea, curved. (Eocene).

Sample 390A-4-5, 75-77 cm (45 m).

Figures 6-10 Oxeas, smooth.

6. Sample $391 \mathrm{~A}-12-5,115-117 \mathrm{~cm}$ (476 m). Miocene.

7. Sample $390 \mathrm{~A}-2-2,75-77 \mathrm{~cm}(21 \mathrm{~m})$. Eocene.

8 , 10. Sample $390 \mathrm{~A}-4-5$, $75-77 \mathrm{~cm}(45 \mathrm{~m})$. Eocene.

9. Sample $387-10-5,120-121 \mathrm{~cm}(210 \mathrm{~m})$. Eocene.

Figures 11, 12 Oxeas, spined.

11. Sample 6-3, CC (194 m). Eocene.

12. Sample 391A-12-5, 115-117 cm (476 m). Miocene.

Figure 13 Oxea, T-branched. (Miocene).

Sample 391A-10-3, 56-58 cm (377 m).

Figure 14 Style, partly spined. (Miocene).

Sample 391A-12-5, 115-117 cm (476 m).

Figures 15-18 Oxeas, mammillary. (Miocene).

15. Sample 338-10-2, $130-132 \mathrm{~cm}(97 \mathrm{~m})$.

16-18. Sample 391A-10-5, 116-118 cm (381 m).

Figures 19-24 Spherasters.

19. Sample $391 \mathrm{~A}-10-5,116-118 \mathrm{~cm}(381 \mathrm{~m})$. Miocene.

20. Sample $390 \mathrm{~A}-7-3,86-88 \mathrm{~cm}(329 \mathrm{~m})$. Eocene.

21 , 22. Sample $391 \mathrm{~A}-12-5,115-117 \mathrm{~cm}(476 \mathrm{~m})$. Miocene.

23, 24. Sample 390A-4-5, $75-77 \mathrm{~cm}$ (45 m). Eocene. 


\section{PLATE 11}

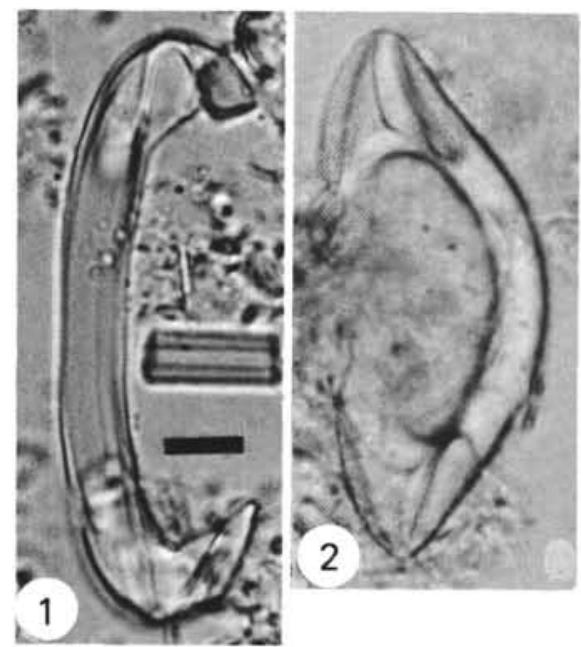

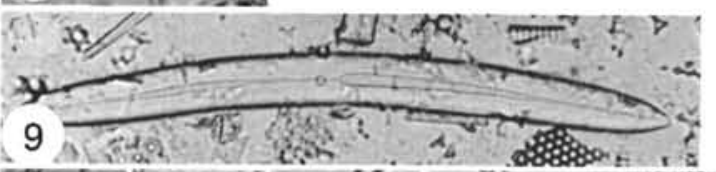

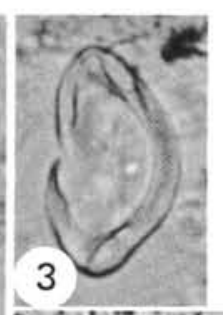

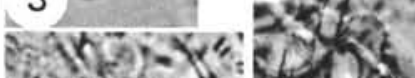
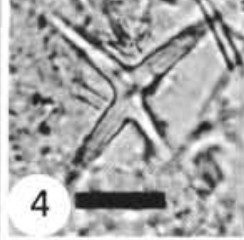
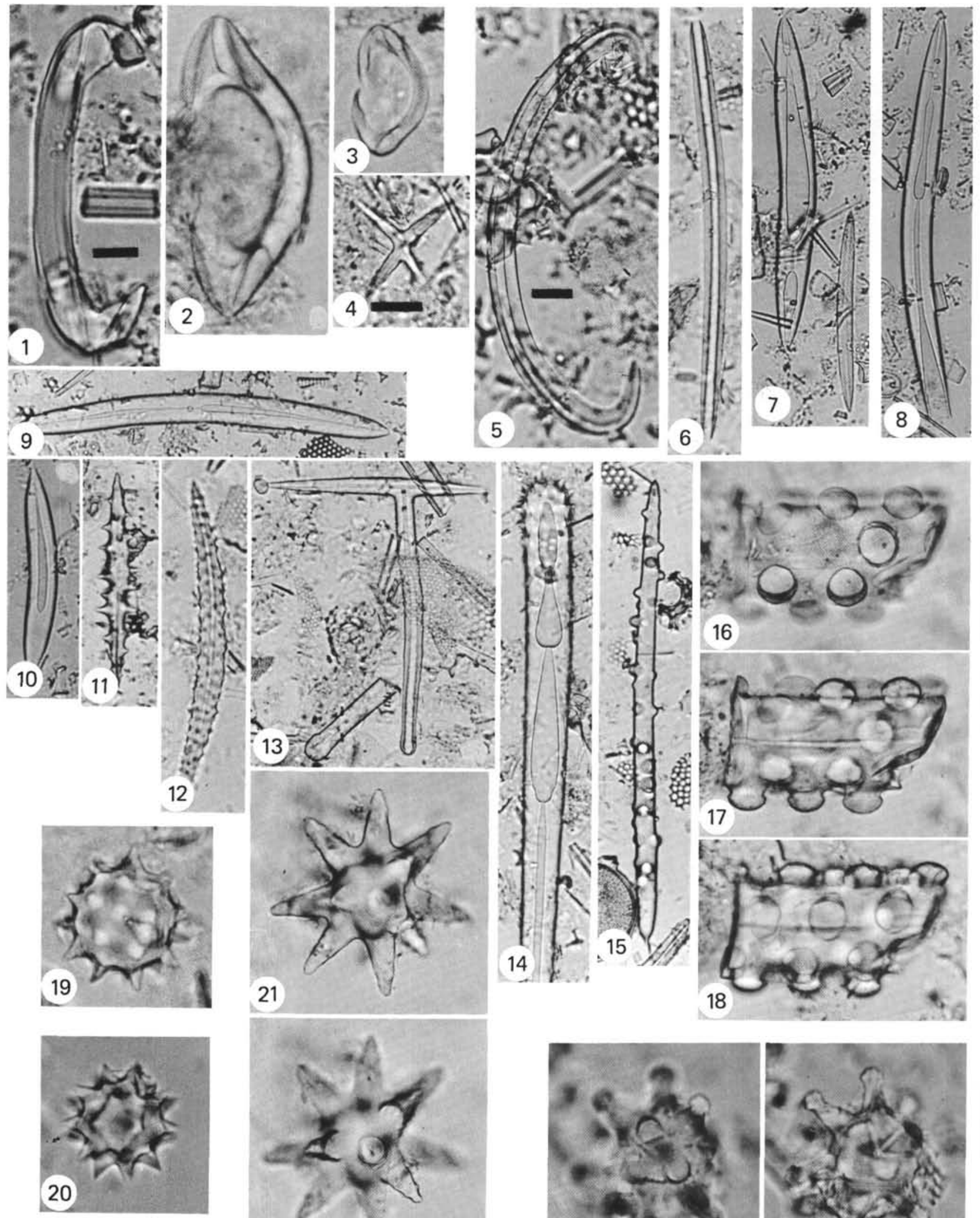
PLATE 12

Siliceous Sponge Spicules From DSDP Leg 44

Figures 1-5, 8-10, 15-17 magnified $800 \times$; scale bar equals $10 \mu \mathrm{m}$.

Figures 6, 7, 11-14 magnified 450X; scale bar equals $20 \mu \mathrm{m}$.

Figures 1-5 Spirasters.

1, 3. Sample 390A-4-5, 75-77 cm (45 m). Eocene.

2, 4, 5. Sample 391A-12-5, 115-117 cm (476 m). Miocene.

Figures 6-16 Sterrasters. (Miocene).

6-10, 13-16. Sample 391A-12-5, 115-117 cm (476 $\mathrm{m})$.

11, 12. Sample 391A-13-1, 53-55 cm (526 m).

Figure 17 Spheraster. (Miocene).

Sample 391A-12-5, 115-117 cm (476 m). 
PLATE 12
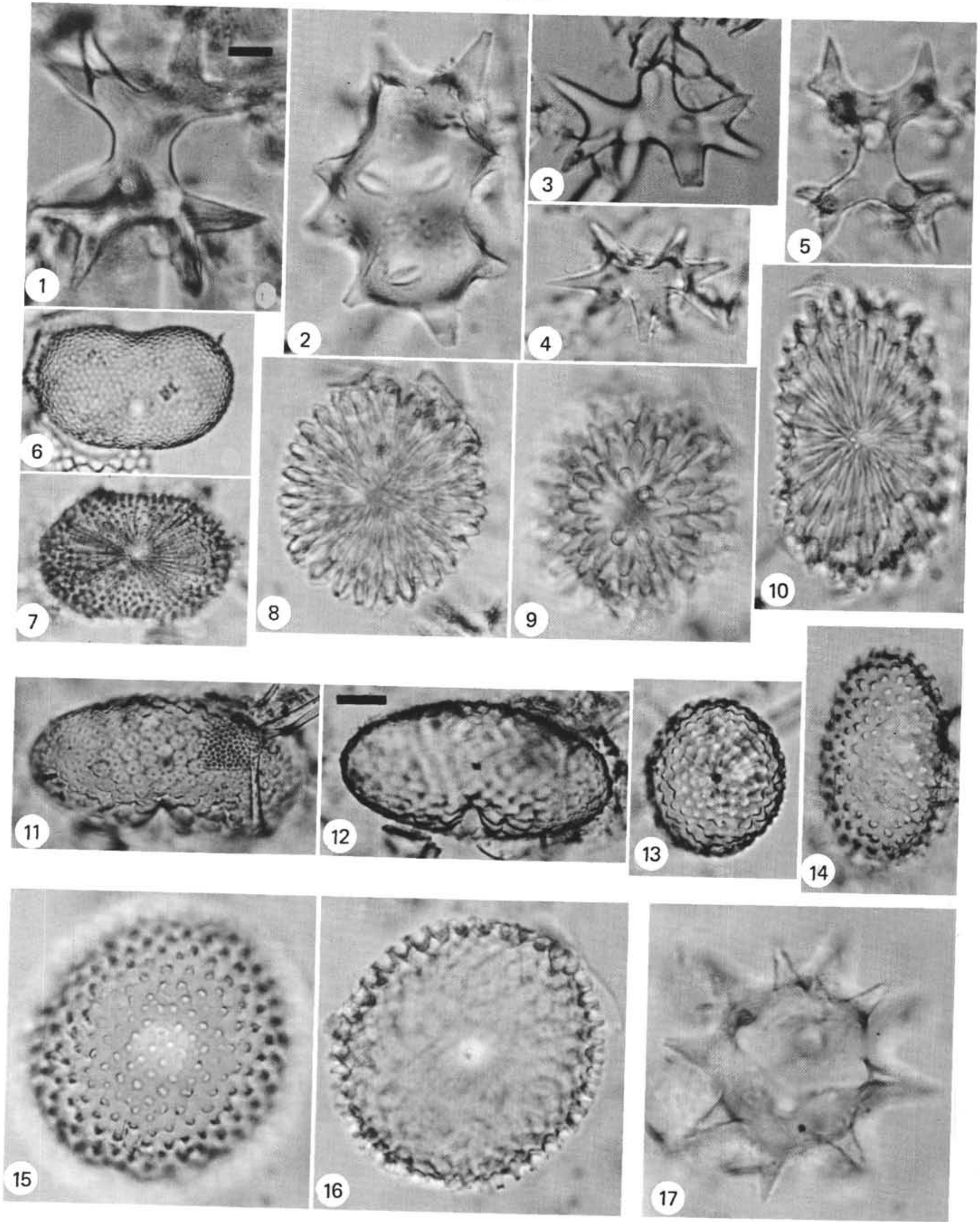


\section{PLATE 13}

Siliceous Sponge Spicules From DSDP Legs 38, 43 and 44

Figures 9, 14, 16, 19 magnified $800 \times$; scale bar equals $10 \mu \mathrm{m}$.

Figures 1-3, 18, 20 magnified $450 \times$; scale bar equals $20 \mu \mathrm{m}$.

Figures 4-8, 10-13, 15, 17 magnified $350 \times$; scale bar equals $20 \mu \mathrm{m}$.

Figures 1-3 Strongyles, smooth. (Miocene).

1. Sample 338-10-2, 130-132 cm (97 m).

2. Sample 391A-12-5, 115-117 cm (476 m).

3. Sample $391 \mathrm{~A}-10-5,116-118 \mathrm{~cm}(381 \mathrm{~m})$.

Figures 4-5 Strongyles, noded. (Miocene).

4. Sample $391 \mathrm{~A}-12-5,115-117 \mathrm{~cm}(476 \mathrm{~m})$.

5. Sample $391 \mathrm{~A}-10-5,116-118 \mathrm{~cm}(381 \mathrm{~m})$.

Figures 6, 7 Styles, smooth. (Miocene).

6. Sample 391A-12-5, 115-117 cm (476 m).

7. Sample $391 \mathrm{~A}-10-5,116-118 \mathrm{~cm}(381 \mathrm{~m})$.

Figure $8 \quad$ Tylote, smooth. (Eocene).

Sample 390A-4-5, 75-77 cm (45 m).

Figure 9 Tylote, verticillately spined. (Miocene).

Sample 391A-12-5, 115-117 cm (476 m).

Figures 10, 11 Tylostyles. (Miocene).

10. Sample $391 \mathrm{~A}-10-5,116-118 \mathrm{~cm}(381 \mathrm{~m})$.

11. Sample $391 \mathrm{~A}-12-5,115-117 \mathrm{~cm}(476 \mathrm{~m})$.

Figure 12 Style, sinuous. (Eocene).

Sample 390A-4-5, 75-77 cm (45 m).

Figure 13 Tylostyle. (Eocene).

Sample $387-10-5,120-121 \mathrm{~cm}(210 \mathrm{~m})$.

Figure 14 Trichotriaene. (Miocene).

Sample 391A-12-5, 115-117 cm (476 m).

Figures 15-20 Triods.

15. Sample $390 \mathrm{~A}-7-3,79-81 \mathrm{~cm}(69 \mathrm{~m})$. Eocene.

16. Sample $390 \mathrm{~A}-4-5,75-77 \mathrm{~cm}(45 \mathrm{~m})$. Eocene.

17, 19. Sample $391 \mathrm{~A}-10-5,116-118 \mathrm{~cm}(381 \mathrm{~m})$. Miocene.

18. Sample 390A-10-3, $56-58 \mathrm{~cm}$ ( $377 \mathrm{~m})$. Eocene.

20. Sample 391A-12-5, 115-117 cm (476 m). Miocene. 
PLATE 13

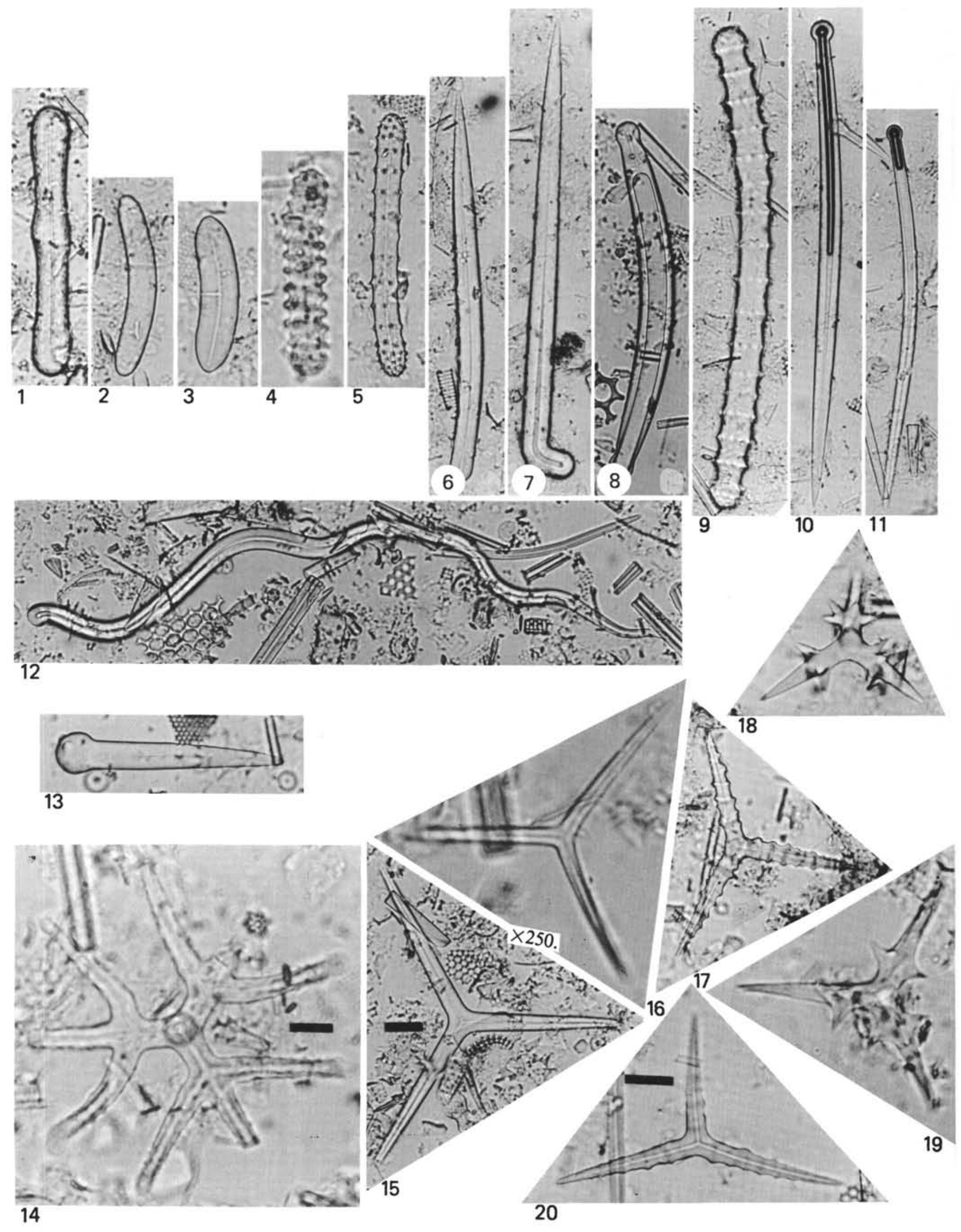


PLATE 14

Miscellaneous Siliceous Sponge Spicules From DSDP Legs 38 and 44

Figures 3-8, 12, 14 magnified $800 \times$; scale bar equals $10 \mu \mathrm{m}$. Figures 1, 2, 10, 11 magnified 450X; scale bar equals $20 \mu \mathrm{m}$. Figure 13 magnified $350 \times$; scale bar equals $20 \mu \mathrm{m}$. $(1-5,7,14:$ Miocene; 6, 8-13: Eocene)

Figures 1, 2 Sample 391A-10-3, 56-58 cm (377 m).

Figure 3 Sample 338-10-2, 130-132 cm (97 m).

Figure 4 Sample 391A-12-5, 115-117 cm (476 m).

Figure 5 Sample 391A-7-1, 96-98 cm (327 m).

Figure 6 Sample 390A-4-5, 75-77 cm (45 m).

Figure 7 Sample 391A-12-5, 115-117 cm (476 m).

Figure 8 Sample 390A-4-5, 75-77 cm (45 m).

Figure 9 Sample 390A-6-3, 75-77 cm (61 m).

Figures 10-12 Sample 390A-4-5, 75-77 cm (45 m).

Figures 13, 14 13. Sample 390A-2-2, 75-77 cm (21 m). 14. Sample 391A-12-5, 115-117 cm (476 m). 
PLATE 14
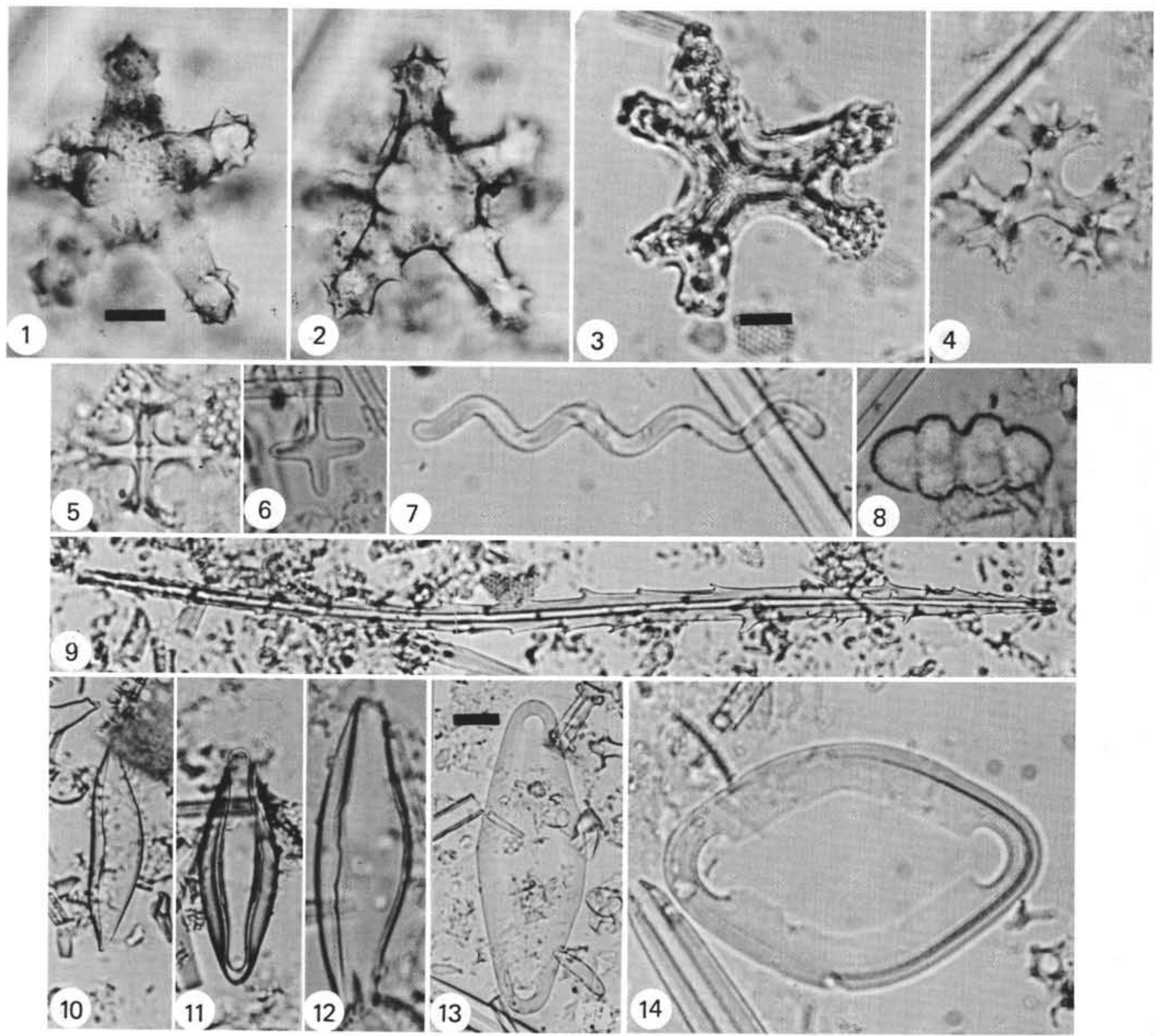


\section{PLATE 15}

Eocene Diatoms From DSDP Leg 44

Figures $1,4,6-8,10-13,15$, scale bar equals $10 \mu \mathrm{m}$.

Figures 3, 9, 14, scale bar equals $20 \mu \mathrm{m}$.

Figures 2, 5, scale bar equals $20 \mu \mathrm{m}$.

Figure 1 Actinoptychus sp.

Sample 390A-2-2, 75-77 cm (21 m).

Figure 2 Arachnoidiscus $\mathrm{sp}$.

Sample 390A-2-2, 75-77 cm (21 m)

Figure 3 Aulacodiscus sp., fragment.

Sample 390A-7-2, 88-90 cm (68 m).

Figure $4 \quad$ Brightwellia sp., fragment.

Sample 390A-2-2, 75-77 cm (21 m).

Figures 5-7 Coscinodiscus oblongus Greville.

Sample 390A-6-3, 75-77 cm (61 m).

6,7 . Same at high and low focus.

Figure $8 \quad$ Coscinodiscus sp.

Sample 390A-6-3, 75-77 cm (61 m).

Figures 9, 10 Hemiaulus spp., asymmetric.

9. Sample 390A-7-2, $88-90 \mathrm{~cm}(68 \mathrm{~m})$.

10. Sample $390 \mathrm{~A}-2-2,75-77 \mathrm{~cm}(21 \mathrm{~m})$.

Figures 11-13 Melosira spp.

Sample 390A-2-2, 75-77 cm (21 m).

Figure $14 \quad$ Pyxilla sp.

Sample 390A-7-3, 79-81 cm (69 m).

Figure $15 \quad$ Rhaphoneis sp.

Sample 390A-2-2, 75-77 cm (21 m). 
PLATE 15
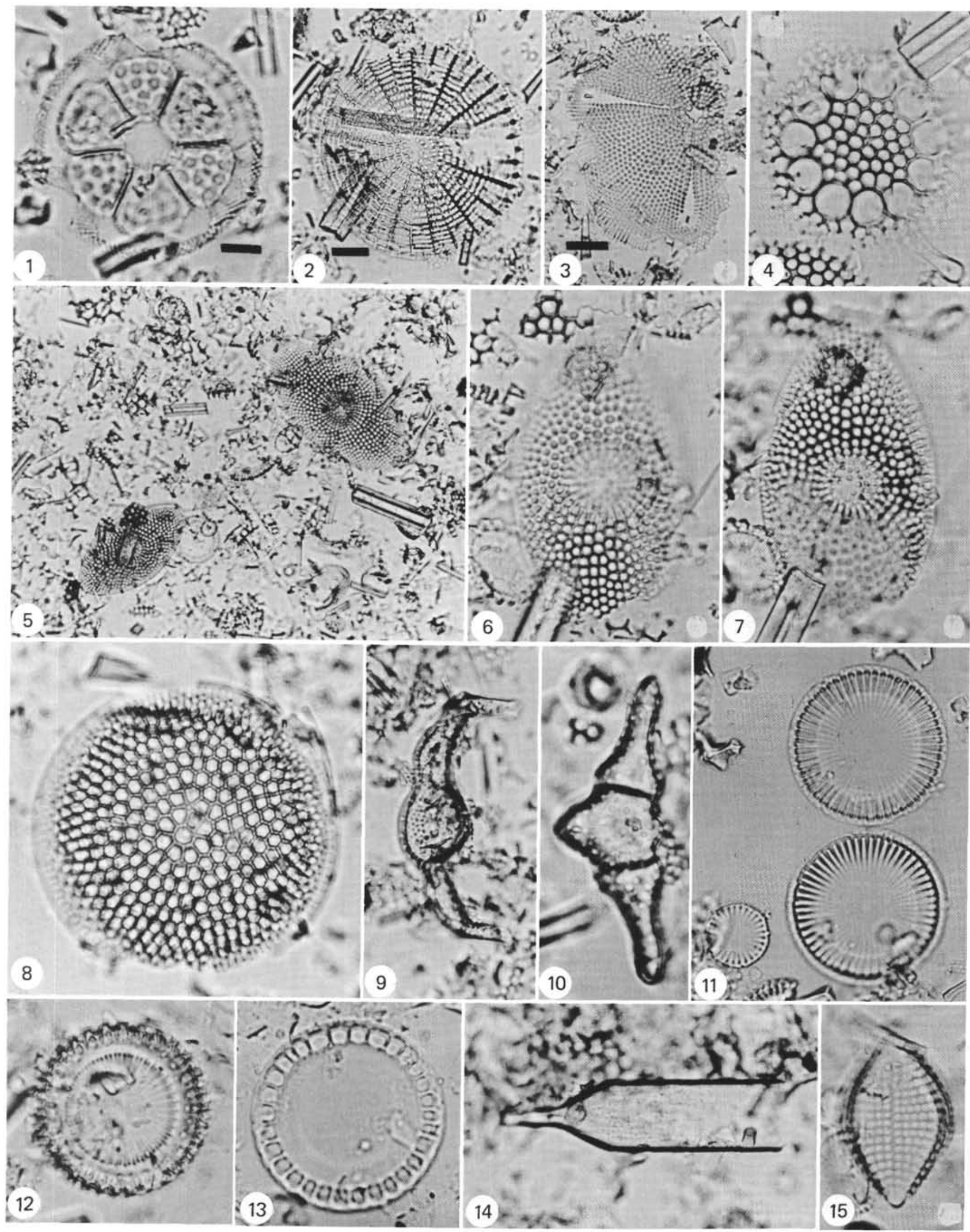
PLATE 16

Eocene Diatoms From DSDP Leg 44

Figures 1-5, 7, 9, 12 magnified $800 \times$; scale bar equals $10 \mu \mathrm{m}$.

Figure 8 magnified $400 \times$; scale bar equals $20 \mu \mathrm{m}$.

Figures 6, 10, 11 magnified 350X; scale bar equals $20 \mu \mathrm{m}$

Figures 1, 2 Rhaphoneis sp.

Sample 390A-2-2, 75-77 cm (21 m).

Figures 3, $4 \quad$ Stephanopyxis sp.

Sample 390A-2-2, 75-77 cm (21 m).

Figure $5 \quad$ Stictodiscus? sp.

Sample 390A-4-1, 78-80 cm (39 m).

Figures 6-9 Triceratium spp.

6, 9. Sample 390A-6-3, $75-77 \mathrm{~cm}(61 \mathrm{~m})$.

7. Sample $390 \mathrm{~A}-2-2,75-77 \mathrm{~cm}(21 \mathrm{~m})$.

8. Sample $390 \mathrm{~A}-7-2,88-90 \mathrm{~cm}(68 \mathrm{~m})$.

Figure $10 \quad$ Trinacria $\mathrm{sp.}$

Sample 390A-6-3, 75-77 cm (61 m).

Figure 11 Diatom group showing diverse outlines.

Sample 390A-2-2, 75-77 cm (21 m).

Figure 12 Diatom sp. A.

Sample 390A-2-2, 75-77 cm (21 m). 
PLATE 16
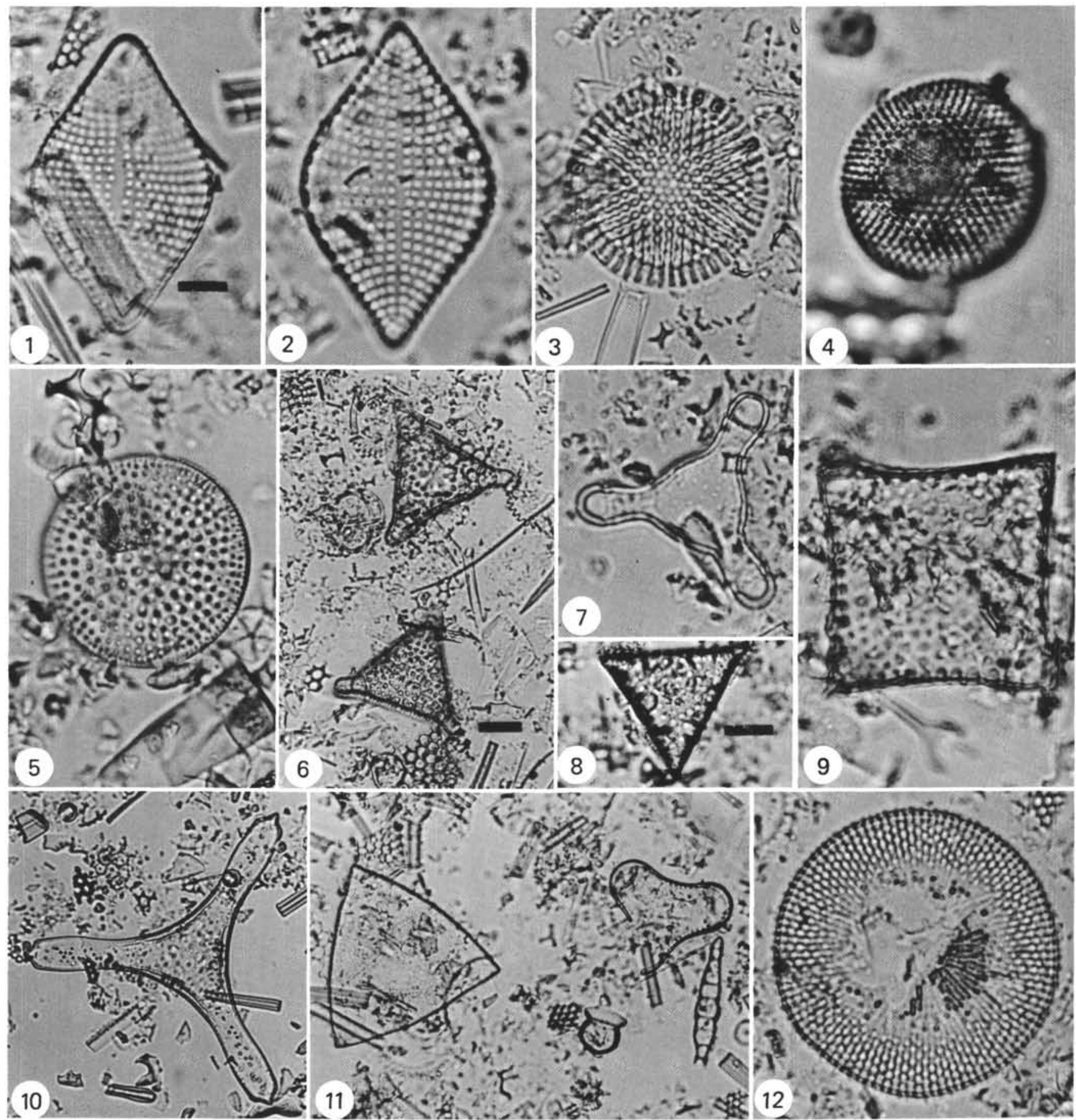


\section{PLATE 17}

Eocene Diatoms, Sponge Spicules, and Silicoflagellate From DSDP Leg 44

Figure 1 magnified $1000 \times$; scale bar equals $10 \mu \mathrm{m}$.

Figures 2-4, 6, 7, 9-12 magnified 800X; scale bar equals $10 \mu \mathrm{m}$.

Figure 5 magnified $400 \times$; scale bar equals $20 \mu \mathrm{m}$.

Figure 8 magnified $350 \times$; scale bar equals $20 \mu \mathrm{m}$.

Figures 1, 2 Diatom sp. A.

Sample 390A-2-2, 75-77 cm (21 m).

Figure 3

Diatom sp. B.

Sample 390A-6-3, 75-77 cm (61 m).

Figures 4, 5 Diatom sp. C.

4. Sample 390A-7-4, 87-88 cm (70 m).

5. Sample $390 \mathrm{~A}-2-2,75-77 \mathrm{~cm}(21 \mathrm{~m})$.

Figure 6 Diatom sp. D.

Sample 390A-2-2, 75-77 cm (21 m).

Figures 7, 9 Diatom sp. E.

Sample 390A-2-2, 75-77 cm (21 m).

Figure 8 Siliceous sponge spicule; microsclere. Sample 390A-2-2, 75-77 cm (21 m).

Figure 10 Diatom sp. F.

Sample 390A-6-4, 75-77 cm (62 m).

Figures 11, 12 Silicoflagellate.

Naviculopsis foliacea tumida n. subsp.

Figured specimen at high and low focus.

Sample 390A-6-3, 75-77 cm (61 m). 
PLATE 17

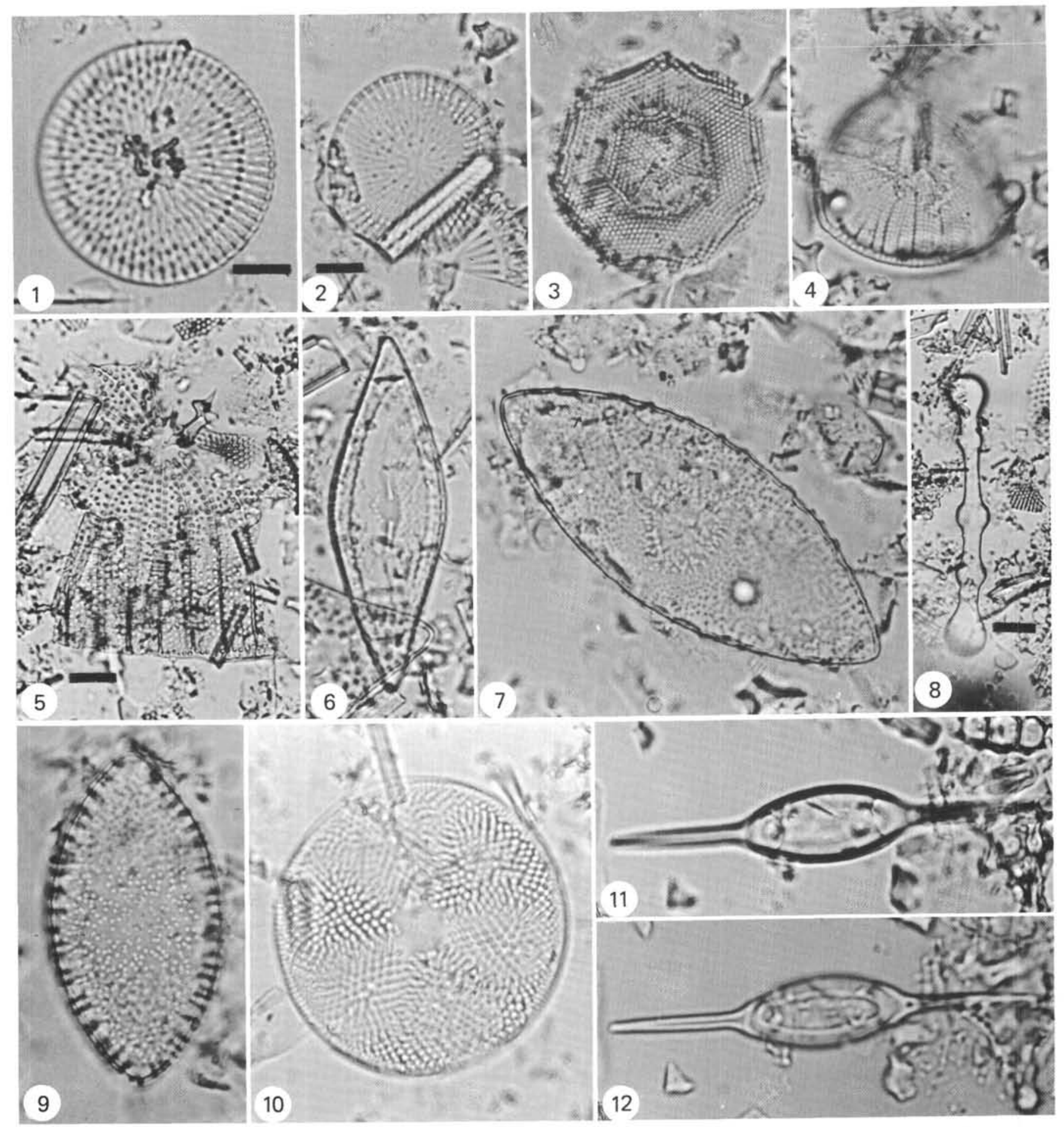


PLATE 18

Miocene Diatoms From DSDP Leg 44

Figure 9 magnified $1000 \times$; scale bar equals $10 \mu \mathrm{m}$.

Figures 1-4, 6, 8 magnified $800 \times$; scale bar equals $10 \mu \mathrm{m}$.

Figure 7 magnified $400 \times$; scale bar equals $20 \mu \mathrm{m}$.

Figure 10 magnified $350 \times$; scale bar equals $20 \mu \mathrm{m}$.

Figures 1, 2 Actinocyclus ingens Rattray.

1. Sample 391A-7-1, $96-98 \mathrm{~cm}(327 \mathrm{~m})$.

2. Sample $391 \mathrm{~A}-7-3,86-88 \mathrm{~cm}(329 \mathrm{~m})$.

Figure 2

Actinoptychus senarius Ehrenberg.

Lower specimen.

Sample 391A-7-3, 86-88 cm (329 m).

Figure 3 Annellus californicus Tempere.

Sample 391A-13-5, 29-31 cm (532 m).

Figure $4 \quad$ Coscinodiscus lewisianus Greville. Sample 391A-12-5, 115-117 cm (476 m).

Figure $5 \quad$ Coscinodiscus asteromphalus Ehrenberg. Sample 391A-13-5, 29-31 cm (532 m).

Figures 6-8 Craspedodiscus coscinodiscus Ehrenberg. 6 , 7. Sample 391A-7-3, 86-88 cm (329 m).

8. Sample 391A-7-1, 96-98 cm (327 m).

Figure 9 Dimerogramma fossile Grunow.

Sample 391A-17-4, 134-136 cm (568 m).

Figure 10 Entogonia jeremiana Bergon.

Sample 391A-12-5, 115-117 cm (476 m). 
PLATE 18

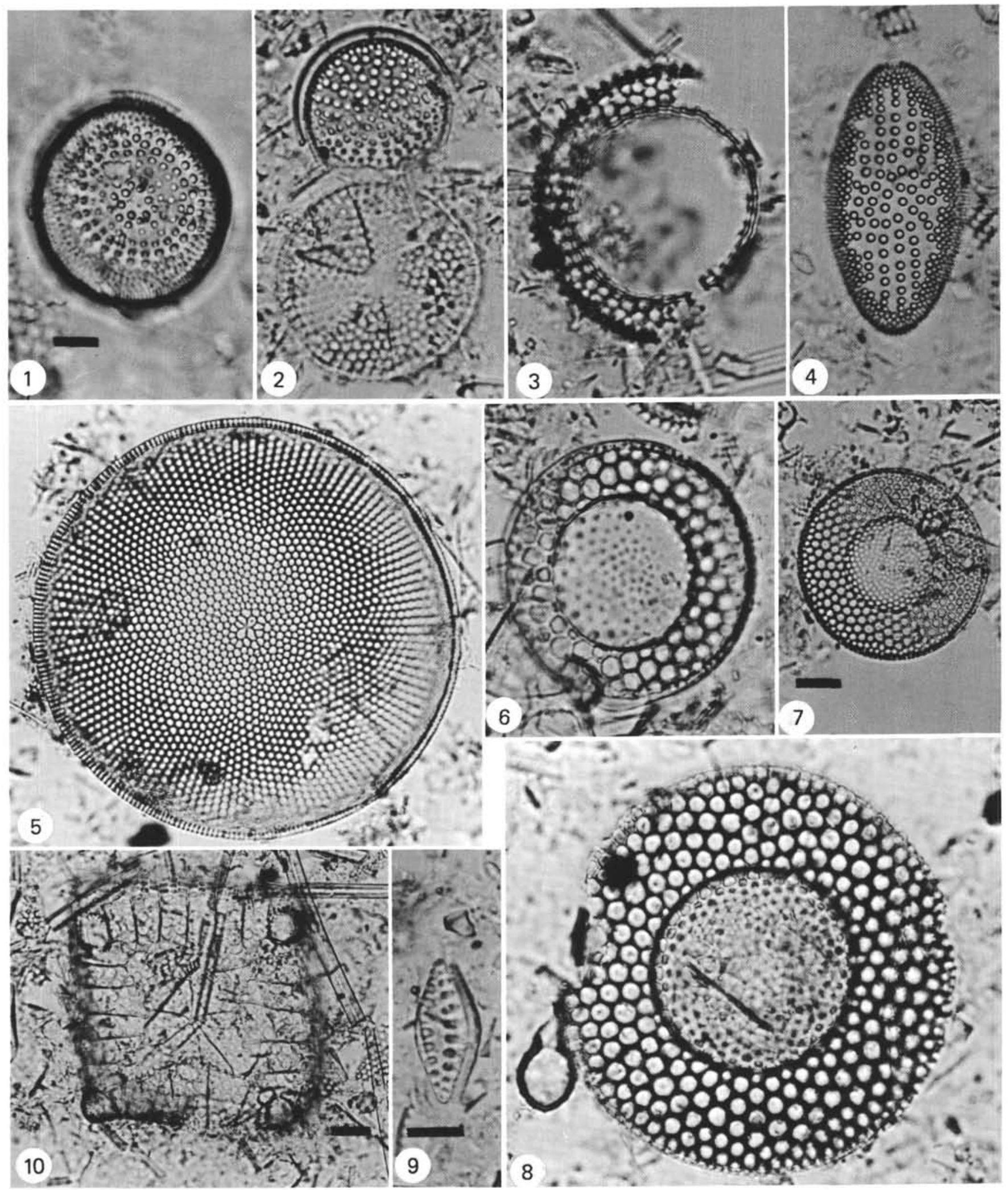




\section{PLATE 19}

Miocene Diatoms and Silicoflagellates From DSDP Leg 44

Figures 9, 15 magnified $1000 \times$; scale bar equals $10 \mu \mathrm{m}$.

Figures 4-6, 8, 10, 11, 16 magnified 800X; scale bar equals $10 \mu \mathrm{m}$.

Figure 2 magnified $400 \times$; scale bar equals $20 \mu \mathrm{m}$.

Figures 1, 3, 7, 12-14 magnified 350X; scale bar equals $20 \mu \mathrm{m}$.

Figure $1 \quad$ Entogonia jeremiana Bergon.

Sample 391A-12-5, 115-117 cm (476 m).

Figures 2-6 Rhaphoneis sp. A.

2. Sample 391A-13-1, 53-55 cm (526 m).

3. Sample $391 \mathrm{~A}-12-5,115-117 \mathrm{~cm}(476 \mathrm{~m})$.

4. Sample 391A-17-4, 134-136 cm (568 m).

5. Sample 391A-19-2, 13-15 cm (585 m).

6. Sample $391 \mathrm{~A}-13-5,29-31 \mathrm{~cm}(532 \mathrm{~m})$.

Figure $7 \quad$ Rhaphoneis gemmifera Ehrenberg.

Sample 391A-7-3, 86-88 cm (329 m).

Figure $8 \quad$ Sceptroneis sp., fragment.

Sample 391A-17-4, 134-136 cm (568 m).

Figure 9 Stephanogonia sp.

Sample 391A-7-3, 86-88 cm (329 m).

Figure $10 \quad$ Stephanopyxis sp.

Sample 391A-7-3, 86-88 cm (329 m).

Figure 11 Thalassionema sp.

Sample 391A-13-5, 29-31 cm (532 m).

Figure 12 Triceratium cinnamomeum Greville.

Sample 391A-13-5, 29-31 cm (532 m).

Figures 13, 14 Diatom sp. G.

Sample 391A-13-5, 29-31 cm (532 m).

Same specimen at high and low focus.

Figure 15 Incertae sedis.

Macrora stella (Azpeitia).

Sample 391A-17-4, 134-136 cm (568 m).

Figure $16 \quad$ Silicoflagellate.

Naviculopsis lata (Deflandre).

Sample 391A-17-4, 134-136 cm (568 m). 
PLATE 19

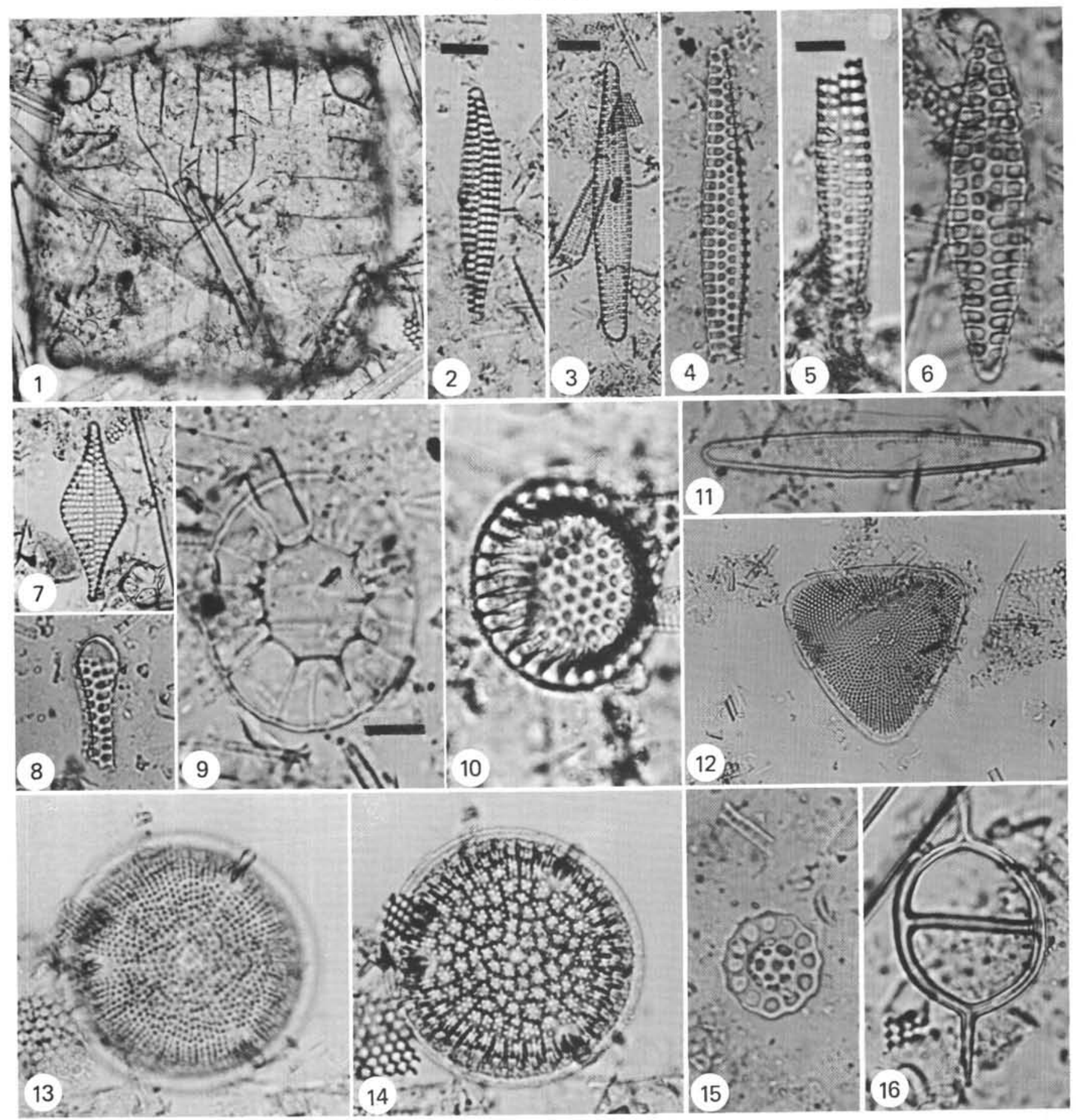

